\title{
Unlocking the inherent potential of plant genetic resources: food security and climate adaptation strategy in Fiji and the Pacific
}

\author{
Hemalatha Palanivel ${ }^{1}$ (D) Shipra Shah ${ }^{2}$ D
}

Received: 20 August 2020 / Accepted: 28 January 2021 / Published online: 17 February 2021

(c) The Author(s), under exclusive licence to Springer Nature B.V. part of Springer Nature 2021

\begin{abstract}
Pacific Island Countries (PICs) are the center of origin and diversity for several root, fruit and nut crops, which are indispensable for food security, rural livelihoods, and cultural identity of local communities. However, declining genetic diversity of traditional food crops and high vulnerability to climate change are major impediments for maintaining agricultural productivity. Limited initiatives to achieve food self-sufficiency and utilization of Plant Genetic Resources (PGR) for enhancing resilience of agro-ecosystems are other serious constraints. This review focuses on the visible and anticipated impacts of climate ge, on major food and tree crops in agriculture and agroforestry systems in the PICs. We argue that crop improvement through plant breeding is a viable strategy to enhance food security and climatic resilience in the region. The exploitation of adaptive traits: abiotic and biotic stress tolerance, yield and nutritional efficiency, is imperative in a world threatened by climatic extremes. However, the insular constraints of Fiji and other small PICs are major limitations for the utilization of PGR through high throughput techniques which are also cost prohibitive. Crop Improvement programs should instead focus on the identification, conservation, documentation and dissemination of information on unique landraces, community seed banks, introduction of new resistant genotypes, and sustaining and enhancing allelic diversity.
\end{abstract}

Keywords Food security $\cdot$ Climate change $\cdot$ Genetic diversity $\cdot$ Crop improvement $\cdot$ Plant breeding $\cdot$ Pacific islands

Hemalatha Palanivel

hemalatha.palanivel@aastu.edu.et

Shipra Shah

shipra.shah@fnu.ac.fj; drshiprashah1984@gmail.com

1 Department of Biotechnology, College of Biological and Chemical Engineering, Addis Ababa Science and Technology University, PO Box 16417, Addis Ababa, Ethiopia

2 Department of Forestry, College of Agriculture, Fisheries and Forestry, Koronivia Campus, Fiji National University, PO Box 1544, Nausori, Republic of Fiji 


\section{Introduction}

The PICs are a group of twenty two countries distributed across Micronesia, Melanesia and Polynesia, with diverse ecosystems both terrestrial and marine which includes tropical rainforests, grasslands, freshwater bodies, salt marshes, coral reefs, seagrasses, mangroves, deep trenches and abyssal plains (Jupiter et al. 2014). These islands therefore generate a diverse array of values related to biodiversity, livelihoods, and local economy. Around three-fourth of the population in the PICs depends on agriculture as a primary or a secondary source of livelihood (ADB 2009). Customary land management systems are found on majority of the island countries in the Pacific, with subsistence farming making significant contributions to the domestic family requirements and supported by traditional barter systems particularly during exigencies (Parkinson 1990; Wairiu et al. 2012). A significant proportion of the calorific demands of the local population is met by the cultivation of vegetatively propagated plants which includes root crops, bananas and plantains (Kirch 2000). A transition from traditional to modern food production systems is however fast gaining hold in the Pacific, with farmers now shifting towards commercial cash crops to meet export demands (Shah et al. 2018). Another serious constraint concerning food production in most PICs is the limited availability of arable land (Wairiu et al. 2012). Increasing human population in the island economies has increased the demand of food resources. Furthermore, it is anticipated that among the developing countries of the world, the PICs are the most vulnerable to climate change (ADB 2009) with the highest risk posed to inhabitants of atolls or low-lying coral islands (Barnett and Adger 2003). This vulnerability to climate change poses a grave threat to food and nutritional security of local communities, and the ability of farmers to meet local food and export demands. Maintaining and enhancing agricultural productivity in the event of saltwater intrusion, rising sea levels, storm surges, (SPREP 2008), prolonged drought, and increasing frequency and intensity of cyclones (Freeman et al. 2012) is indisputably challenging. The problem of low fertility of atoll soils is compounded by salinization of freshwater lenses which lie over the transition zone to sea water (Fletcher and Richmond 2010). Greater damage by insects, pests and diseases to food production systems in the Pacific is anticipated due to increased biotic and abiotic stress on plants, and the incursion of novel pests and diseases as reported in the islands of Tonga, Vanuatu, Kiribati and Tuvalu (Freeman et al. 2012). Despite these challenges and limitations, crop productivity can be enhanced through well-adapted, resistant and high yielding varieties.

Adaptation is a dynamic process brought about through an organism's interaction with its environment. Adaptation to climate change may not necessarily be a matter of preserving valuable genotypes in cryogenic banks. Another prudent approach is to cultivate and breed tolerant cultivars under field conditions in various agro-climatic zones where they are exposed to a wide range of climatic, edaphic, biotic and abiotic factors (Raza et al. 2019; Hasan et al. 2018). Biotic resources have the capacity to adjust to changes in abiotic factors such as heat, drought or salinity, and this enables ecosystems to cope with the consequences of changing environments. Genetic resources are utilized by farmers and plant breeders for adaptation to changes in socio-economic and environmental challenges (Westengen and Brysting 2014). Despite the fundamental importance of agrobiodiversity for future food security, the subject has received little attention in international debates on climate change adaptation. When discussed within various international development initiatives, adaptation to climate change in the agriculture sector is driven by concerns on the increased frequency of droughts and floods, and 
therefore focuses primarily on improved water management. However, conservation and efficient utilization of genetic resources should be aligned with climate change adaptation as a cost-effective strategy. Crop productivity can be enhanced through resistant and high yielding varieties under environmental stresses. Hence, genetic improvement through conventional and modern plant breeding techniques and tools may be among the most appropriate approach for climate adaptation in the agriculture sector.

Initiatives have been put in place to improve the adaptation of farming systems to climate change, and a number of strategies have been suggested and implemented by researchers globally. Swaminathan and Kesavan (2012) have recommended utilizing the genes for salinity tolerance from mangrove species and halophytes for developing salttolerant varieties. The establishment of community seed banks of local genetic diversity which have a high degree of resistance to biotic and abiotic stress has also been proposed as a cost-effective strategy (Vernooy et al. 2017). As per Schiffman (2014), the 1750 seedbanks globally are the Noah's ark for agrobiodiversity, with organizations such as Native Seeds/SEARCH housing a diversity of unique landraces to strengthen food systems. The Svalbard global seed vault in Norway houses crop diversity as an insurance against climate change (Qvenild 2012). More than a quarter of the world's banana diversity is stored at the International Musa Germplasm Transit Centre (ITC) at the Katholieke Universiteit Leuven, Belgium, through cryopreservation (Umesha 2005). Within the Pacific region, in 1998 the Pacific Community (SPC) established the Regional Germplasm Centre (RGC) which is now known as the Centre for Pacific Crops and Trees $(\mathrm{CePaCT})$. The centre has around 2000 accessions, including around 1000 accessions of taro; the largest collection of taro diversity globally. The initial focus on taro has widened to include other staple crops of the region such as yam, sweet potato, banana, cassava and breadfruit. CePaCT has distributed over 70,000 tissue culturederived plantlets to 51 countries, including 22 countries and territories in the Pacific for improved accessibility to both traditional and improved crops selected for desirable characteristics (Kumar 2017). Under the UN FAO International Treaty on Plant Genetic Resources for Food and Agriculture (ITPGRFA), Pacific Agricultural Plant Genetic Resources Network (PAPGREN) was initiated in 2001 to spearhead the conservation and use of PGR for food and agriculture in the Pacific. The network was funded by the Australian Centre for International Agricultural Research (ACIAR) and New Zealand Agency for International Development (NZAID) during Phase 1 and NZAID during Phase 2; technical support was provided by Biodiversity International in both Phases. With a membership of 22 Pacific countries, PAPGREN has developed a Pacific Agricultural PGR Action Plan (APAARI 2011). SPC's Pacific Seeds for Life (PS4L) project (2020-2024) was introduced to strengthen seed systems and improve the availability, access and use of climate resilient and nutritious crops. This project recently donated $350 \mathrm{~kg}$ vegetable seeds and 400 tissue culture plants to Fiji's Ministry of Agriculture in response to TC Harold relief efforts and the COVID-19 global pandemic. Apart from SPC, the National Agricultural Research Institute (NARI) in PNG, Vanuatu Agricultural Research and Technical Centre (VARTC) in Vanuatu and University of South Pacific's Alafua Campus in Samoa, have some technical expertize in the region on plant breeding and crop improvement. The genetic diversity of plants undeniably has significant potential to salvage farmers and farming systems in an era of rapid climate change. This paper focuses on the visible and anticipated impacts of climate change, on major food and tree crops in agriculture and agroforestry systems in the PICs. The researchers suggest crop improvement strategies that can be initiated in small island countries keeping in mind their remoteness and insularity. 


\section{Climate change in Fiji and the Pacific}

The islands of the Pacific (Fig. 1) due to their small geographical size and low-lying topography are highly vulnerable to climate change (Hauger 2015). Inundation and flooding, beach erosion, and salt water intrusion are the primary visible impacts of climate change which have started threatening the livelihoods of the island people (Mimura 1999). Climate-induced migration has become an unfortunate reality for the Pacific with rising sea levels and tidal surges compromising livelihoods and food security (Burson 2010). In 2005, intensive damage caused by storms, erosion and saltwater intrusion resulted in forced migration of the people of Lateu village in Vanuatu (Brown 2008). In the same year, the people of Carteret islands in Papua New Guinea (PNG) migrated to the mainland due to rising sea levels, saltwater intrusion and storm damage (Hingley 2017). These two populations are labelled as the world's "first climate refugees" in history (Brown 2008). In early 2014 due to rising sea levels, Vunidogoloa became the first village in Fiji to relocate to higher ground (McNamara and Combes 2015).

Increased temperatures, more frequent and prolonged dry spells, erratic rainfall patterns, salt water intrusion, increasing soil erosion and cyclones have progressively put burden on crop production in both commercial and subsistence agriculture in PICs. The observed and projected changes in climate and their key consequences are summarized in Table 1. Increase in temperature and shifts in precipitation patterns have been observed across the Pacific region (Church et al. 2013; Christensen et al. 2013). Variable increases in sea level across the Pacific have been observed along with increased storm surges, king tides and saltwater intrusion (Masson-Delmotte 2018). Sea surface temperatures (SSTs) have increased by $0.456{ }^{\circ} \mathrm{C}$ over the period 1950-2009 in the western South Pacific. Using

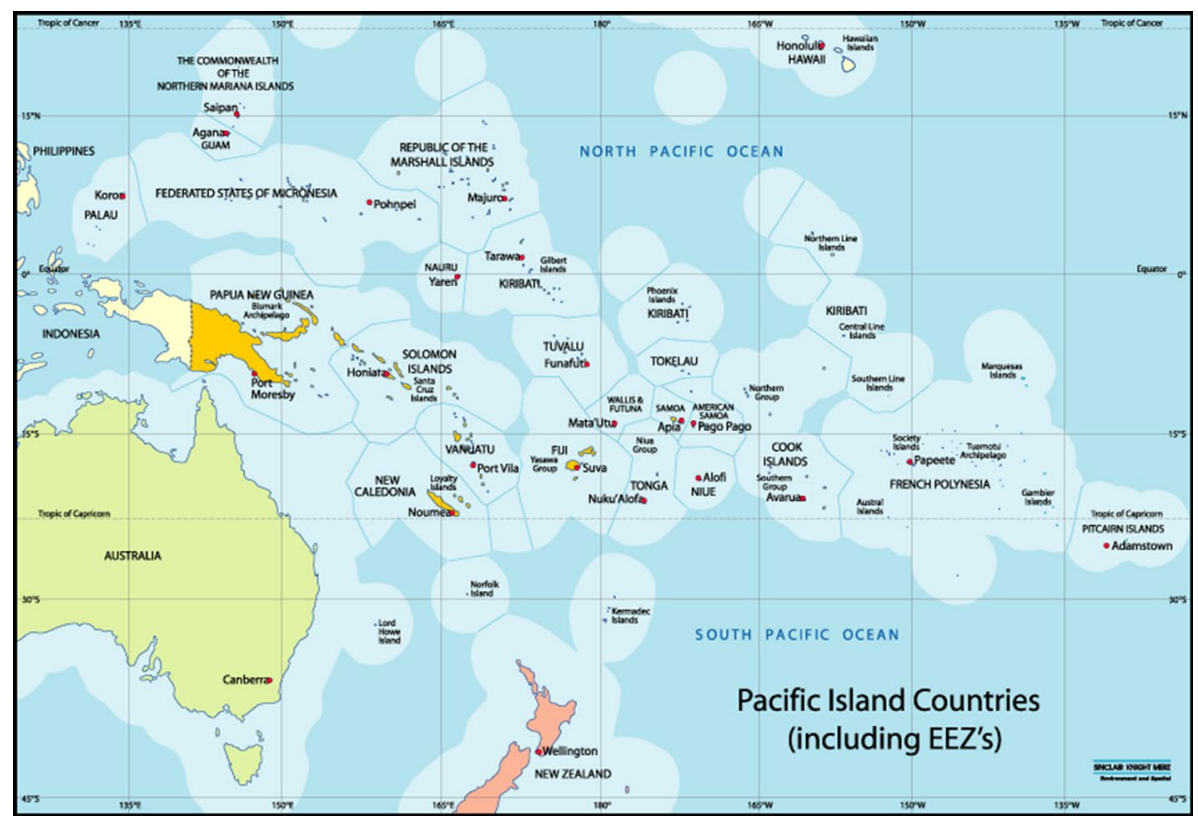

Fig. 1 Map of the PICs. Source (http://www.tunapacific.org/) 


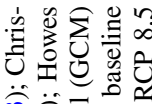
商守 ज。 可产

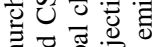
己

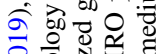

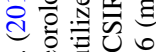
สं 过 券守出 产产这论

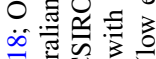
需记 3 궁

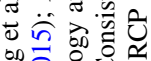

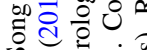
की

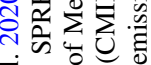

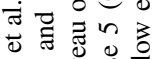
表

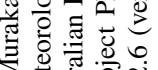
可

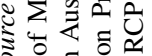
额 氖言焉

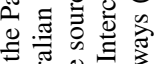

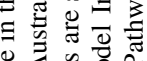

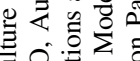

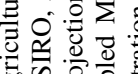
空记高

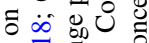

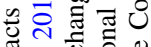

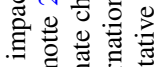

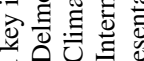

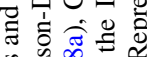

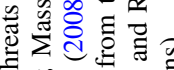

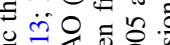
言究焉

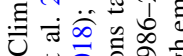

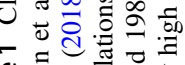

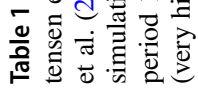

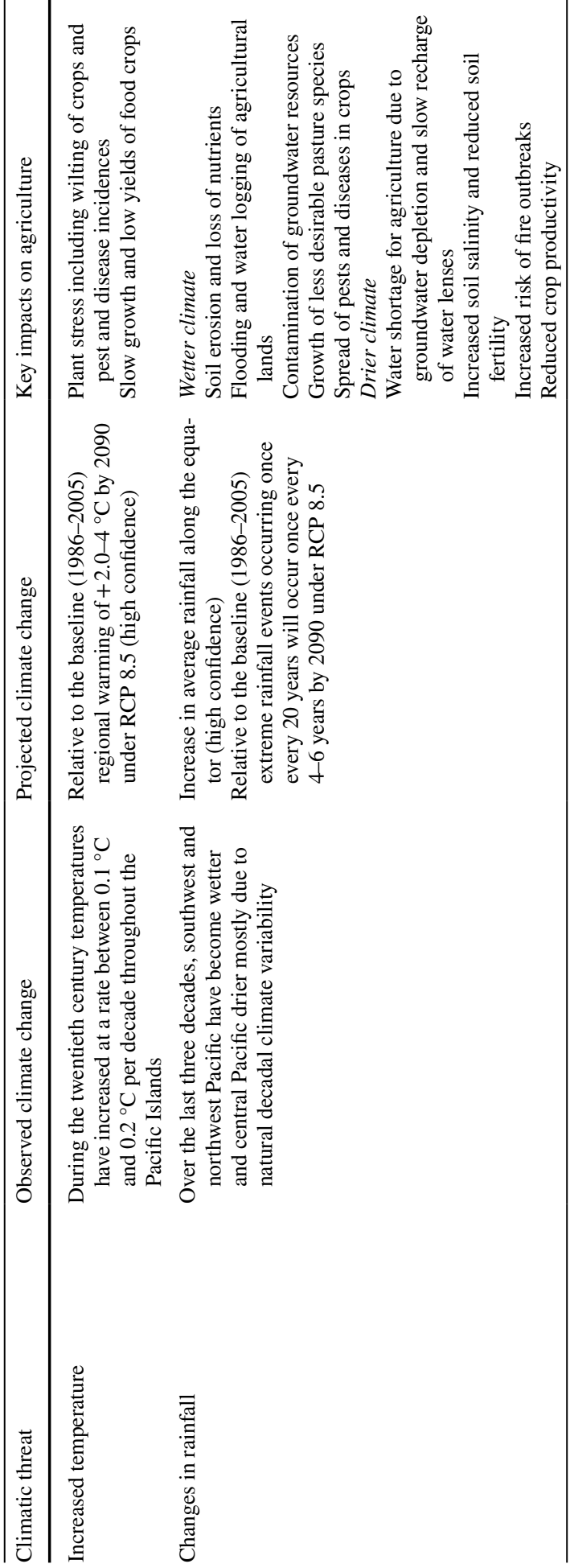




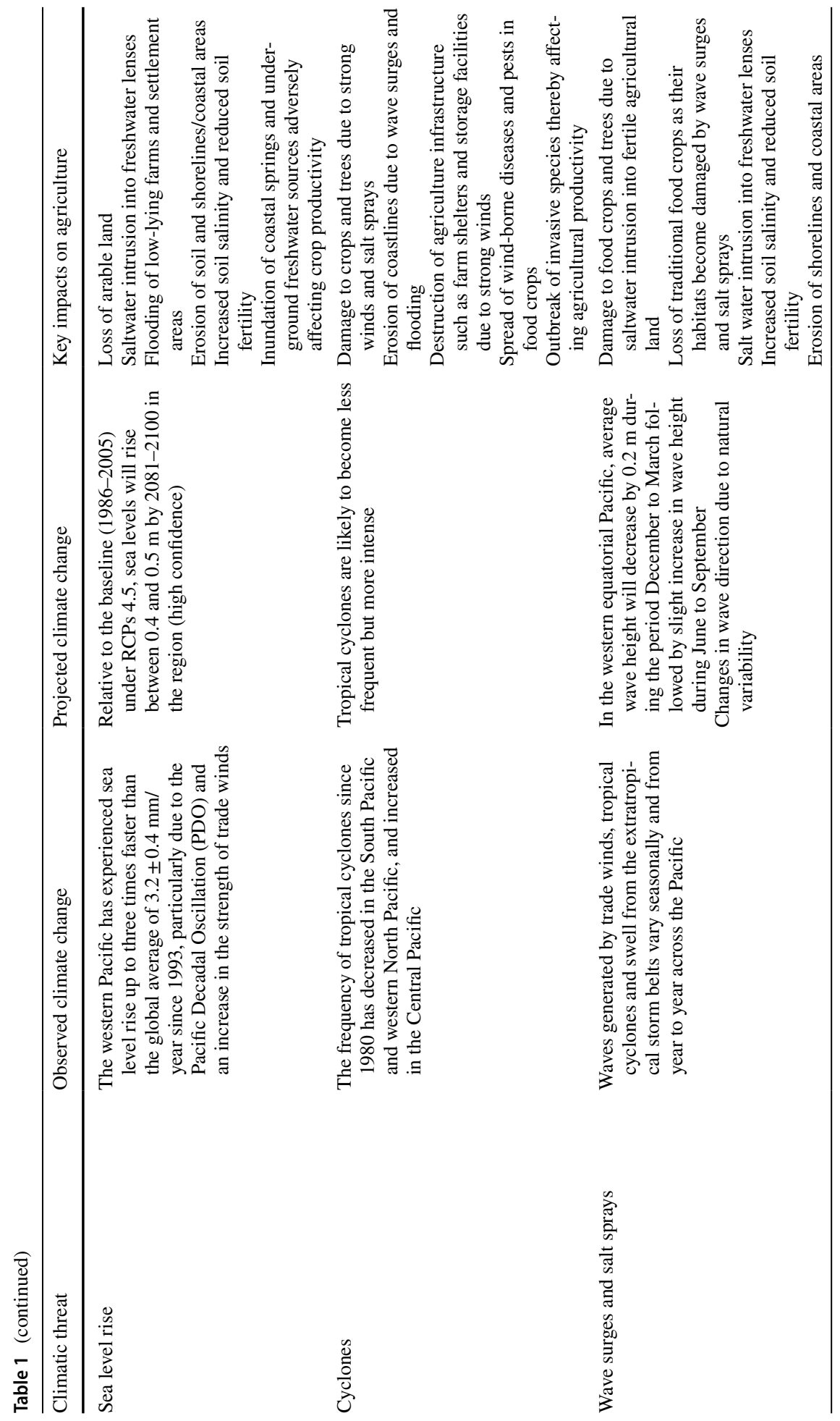




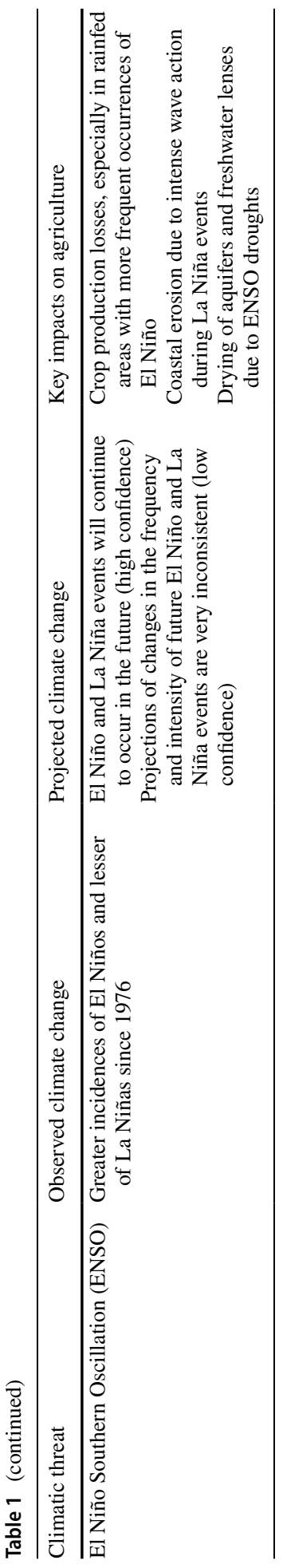

Springer 
the Coupled Model Intercomparison Project Phase 5 (CMIP5 model), under RCP 8.5, SSTs are projected to increase by $1.8-2.8^{\circ} \mathrm{C}$ towards the end of the twenty-first century (Howes et al. 2018).

In time, the frequency and intensity of climatic extremes is becoming more pronounced. El Nino-Southern Oscillation (ENSO) has a profound impact on interannual changes in precipitation, sea level, and other climatic variables (Murphy et al. 2014). While there is high confidence that ENSO will remain the dominant mode of interannual climatic variability this century, there is low confidence in terms of the intensity and spatial pattern of El Niño (Christensen et al. 2013; CSIRO, Australian Bureau of Meteorology and SPREP 2015). Since 1993 sea level rise in the western Pacific has been three times faster than the global average, particularly due to the Pacific Decadal Oscillation (PDO) and more intense trade winds (Howes et al. 2018; Oppenheimer et al. 2019). As per the IPCC Special Report on the impacts of global warming of $1.5^{\circ} \mathrm{C}$ above pre-industrial levels (Masson-Delmotte 2018), in the South Pacific Islands changes in the frequency of extreme El Niño and La Niña events may increase the frequency of droughts and floods. In 1997-1998, almost the whole of western Melanesia was influenced by an ENSO drought with severe impacts on agriculture and livelihoods in Fiji and PNG. In Fiji, an El Nino event reduces the annual rainfall by as much as $20-50 \%$ resulting in severe implications for farming communities (Government of Fiji 2012). While the frequency of tropical cyclones has declined in the South Pacific and western North Pacific (Murakami et al. 2020), the storm severity has increased (Song et al. 2018). In Fiji, a decrease in the frequency of cyclones in the last decade was accompanied by a massive increase in their intensity (Government of Fiji 2012). On the 20th of February 2016, the country was hit by Tropical Cyclone (TC) Winston; a category 5 tropical storm which was the strongest cyclone to make landfall in Fiji and also the strongest recorded cyclone in the Pacific basin. In the islands of Fiji, PNG, and Solomon islands, river flooding is a severe problem and is commonly associated with cyclones and extreme rainfall events. In 1993, Cyclone Kina in Fiji predisposed massive floods that submerged around 21,700 ha (McGregor and McGregor 1999). Sea flooding commonly occurs during the passage of tropical cyclones and are frequently associated with king tides which submerge coastal areas (Government of Fiji 2012). However, as per Lander (2004), it is difficult to analyse changes in the climate of the Pacific region since these changes are a result of both natural and anthropogenic interactions. Therefore, climate adaptation strategies for the region are complex to elaborate and have to be designed for diverse local situations (Barnett 2001).

\section{Key Pacific food production systems}

The agriculture sector including forestry and fisheries holds special significance in the Pacific region. Subsistence food production forms a significant part of household income, sometimes being more than 50\%, although it varies widely among and within countries (McGregor et al. 2009), and is as high as $80 \%$ in PNG (Iese et al. 2018). Agriculture is a valuable source of livelihood in Tonga, Samoa, Timor-Leste, Cook Islands, Kiribati, Federated States of Micronesia (FSM) and Tuvalu. The dependence on farming as a percentage of the rural population is around 80\% in Solomon Islands, 70-80\% in Vanuatu and 50-60\% in Tonga (Iese et al. 2018). In Niue and Marshall Islands, the economic contribution of agriculture is limited whist in Nauru, Palau and atolls of the Pacific it is insignificant (SPC 2011). This is primarily due to the small geographical size, and limited availability of 
land and PGR for production of agricultural commodities based on existing crop varieties. Cash cropping and subsistence farming are the two primary forms of agricultural systems, around $70 \%$ of which are rainfed and therefore highly vulnerable to changes in precipitation patterns (FAO 2008a).

Traditional Farming Systems (TFSs) are still prevalent in most of the islands. Although TFSs include different forms of shifting cultivation; soil water management practices such as pond-field, raised-bed, atoll-pit cultivation and terrace garden systems also exist (FAO 2010). Traditional food production in the Pacific is based on agroforestry (fruit, nut and other tree species), complemented and occasionally dominated by a high degree of dependence on a variety of wild food and other services such as fuelwood and medicine (HeluThaman 2008). These farming systems are, however, increasingly threatened by globalization, urbanization and modern agriculture which has resulted in intensification of farming on small land holdings as well as expansion into steep, marginal and forested lands (FAO 2010). Such trends are evident in Fiji, PNG, Vanuatu and Tonga. Another aspect is the high dependence of Pacific Islands on food imports which threatens food and nutritional security (McGregor et al. 2009). However, in the next fifty years it is anticipated that rising cost of fuel required for the distribution of imported food to remote areas and erratic nature of supplies due to climate change may compel a shift towards local food production systems which are also resilient to climate change (Mertz et al. 2012; Zhou et al. 2014). An interesting scenario has been observed in Bellona, Solomon Islands, where due to the erratic nature of external food supplies and frequent breakdown of ships, traditional farming systems emerged as an important source of local food for the people (Mertz et al. 2012). This highlights the need to strengthen local food resources by the development and exploration of resistant cultivars, and the promotion of genetic diversity in farming systems. Such initiatives would also require concerted efforts to identify the impacts of climate change on vulnerable food crops.

\section{Impacts of climate change on some major Pacific crops and breeding interventions}

An analysis of the food production indices in the Pacific reveals that towards the mid-1990s there was a decline in the production indices with most of the countries reporting either stagnation or only a marginal rise in production thereafter. Furthermore, it is interesting to note that increases in production index are primarily attributable to an expansion of the total area under cultivation and are not actual increases in yield (ADB 2011). In Fiji, the agricultural Net Per Capita Production Index declined from 122.09 in 1990 to 76.13 in 2016 (Fig. 2). Over the period 1991-1997 production indices were more or less stable, despite there being a drop towards the close of the decade as evident during the $1998 \mathrm{El}$ Nino drought in Fiji. The total planting area of sugarcane in western Viti Levu was around 70,400 ha in 1998 , out of which 17,300 ha, i.e. one-fourth of the crop was wiped out due to the hydrological drought. This resulted in a production loss of 50\% (2 million metric tons) equivalent to FJ\$104 million (Lightfoot 1999). Production indices have struggled to maintain consistency at the turn of the century, with sharp declines over the period 2000-2016. This trend in agricultural production coincides with extreme weather events in Fiji including flash floods and severe tropical cyclones (Fig. 2). The impacts of climate change on some of the important agricultural crops of the Pacific, and possible plant breeding 


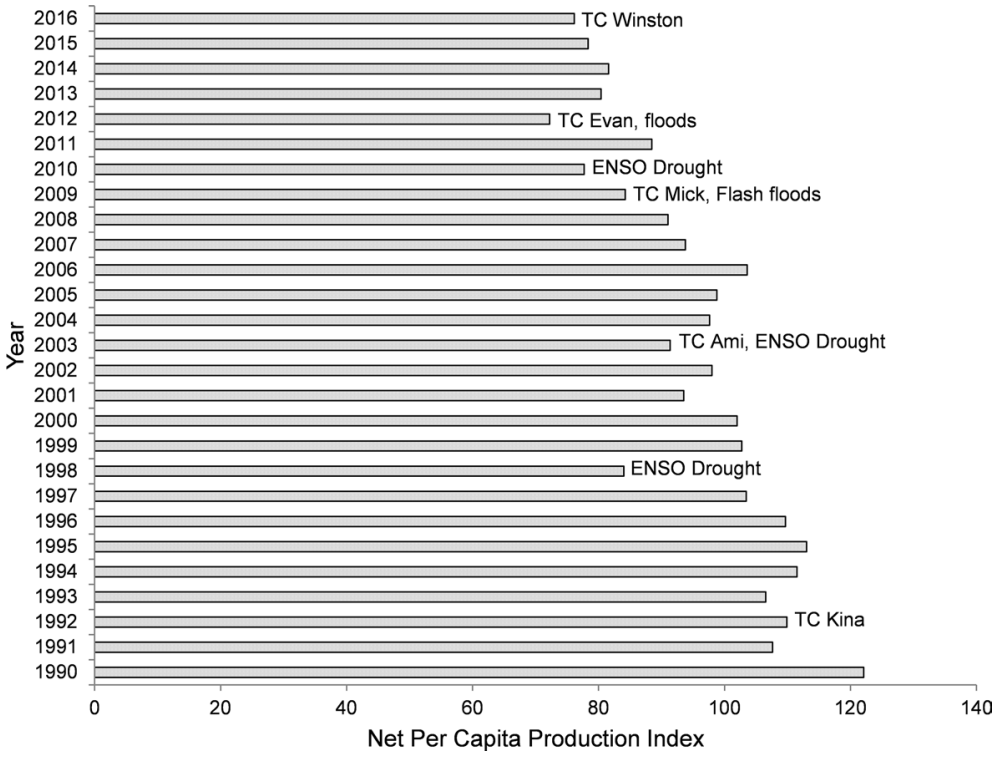

Fig. 2 Net per capita agriculture production index for Fiji from 1990 to 2016 and major climatic extremes. Source FAOSTAT (2020)

interventions to enhance resilience of food production systems to climate change are presented in the following sub-sections.

\subsection{Root/tuber crops}

In the PICs, root and tuber crops such as taro, giant swamp taro, cassava, sweet potato and yam are important components of the diet of the local communities particularly in rural areas. These crops are valuable for food and nutritional security, and are capable of producing relatively higher nutrition and energy per unit area and time compared to other staples (Muimba-Kankolongo 2018). They also contribute to the income and livelihood of farmers in rural areas under diverse environmental conditions. However, root and tuber crops are vulnerable to climatic variability which may have serious impacts on food production.

\subsubsection{Taro}

Taro is among the most popular root crops and is a major staple. It is anticipated that in PNG, while taro yields may decline by $13 \%$ due to climate change in 2050 compared to the year 2000, adaptation through resistant cultivars can reduce these losses by half. In Fiji and Solomon Islands under a high fertilizer scenario, rainfed taro yield losses in 2050 may range between $3.9-17.5 \%$ and $7.4-16.1 \%$, respectively, compared to the year 2000. It might be possible to reduce those losses to around $2.5-12.3 \%$ and $6.4-12.4 \%$, respectively, if optimal cultivars and planting months are adopted as adaptation strategies (Rosegrant et al. 2015). Taro is highly susceptible to pest damage under adverse environmental conditions. The taro caterpillar or armyworm (Spodoptera litura) is widespread in the Pacific and outbreaks generally occur in the aftermath of cyclones 
particularly when followed by dry weather conditions. This was witnessed in Samoa where a severe armyworm epidemic was reported six months after Cyclone Val in 1991 (Liyanage and Misipati 1993; Carmichael et al. 2008). Future climate warming is likely to change the distribution of lepidopteran insects with poleward shifts in geographical ranges (Parmesan et al 1999). Marker-assisted breeding to identify major QTLs for antibiosis and antixenosis resistance for army worm will be a potential approach to overcome the outbreak of the insect (Oki et al. 2017). Resistance genes derived from the genetically distant wild progenitor are probably unique although not yet reported. However, the Palauan landrace 'Dirratengadik' has been used to map QTL for TLB resistance (Bellinger et al. 2020) and can be used for crossing taro genetic resources. In Samoa poorly drained soils under high rainfall conditions increase incidences of taro crop damage by corm rot (Pythium spp.) (Liyanage and Misipati 1993). Some varieties however have been identified as resistant to corm rot: Tusi Tusi, Talo Vale, Pute Mu and Pula Sama Sama (Carmichael et al. 2008). The Taro Leaf Blight (TLB) (Phytophthora colocasiae) epidemic devastated taro crop in the Samoan Archipelago from 1993-1994. In 1993, immediately before the epidemic, taro constituted 58\% of Samoa's agricultural exports and generated an annual revenue of US\$3.5 million which plummeted to $<$ US $\$$ 60,000 in 1994. Samoa's taro crop was ravaged by TLB because taro monocultures with no leaf blight resistance were under cultivation with very little genetic variance. Furthermore, environmental conditions during the epidemic were favourable for rapid spread of the disease: strong winds, high relative humidity and nighttime temperature (McGregor et al. 2011). Although there are around two thousand varieties of taro in the Pacific, due to the lack of selection pressure for identifying resistant genotypes prior to the epidemic, the monoculture of susceptible varieties resulted in large scale devastation of the crop (Hunter et al. 1998). Ever since in counties including Western Samoa, Fiji, Vanuatu, Solomon Islands and PNG, taro breeding programmes for developing resistance to TLB, improved yield and corm quality have been initiated. The TaroGen project, funded by the Australian Agency for International Development (AusAID), started in 1998 and led to the collection of around 2300 taro accessions and elite cultivars from 10 PICs (Singh et al. 2002), out of which a regional core collection of 196 accessions was formed and SPC's CePaCT was mandated to conserve and share accessions of this core collection with the PICs for breeding purposes (Mace et al. 2006) With funds provided by ACIAR, the University of Queensland supported DNA fingerprinting and virus indexing of the taro core collection. This approach allowed the safe movement of germplasm from the CePaCT to the Taro Improvement Project (TIP) (Iosefa et al. 2012; Hunter et al. 2000; Anonymous 2010) which was established with support from TaroGen at the University of the South Pacific in Samoa. In the humid tropics where annual rainfall is greater than $2500 \mathrm{~mm}$, TLB is a serious problem for taro growers (McGregor et al. 2011). The life cycle of $P$. colocasiae depends on environmental conditions particularly temperature and rainfall. High temperature and humidity are conducive for spore germination and favour the onset and spread of TLB, with initial infections occurring on leaves where rainwater, dew or guttation droplets accumulate (Bourke and Allen 2009; Carmichael et al. 2008; Onwueme 1999; Singh et al. 2012). A consistent breeding strategy is recurrent selection for identifying less susceptible lines and incorporating these in intercrossing and hybridization programmes. The resistant wild forms of Taro from Vanuatu can be used in breeding programmes to develop TLB-resistant cultivars in the Pacific region (Lebot et al. 2001) Another promising approach is participatory plant breeding to broaden the genetic base for improving and managing TLB (Hunter et al. 2000; Lebot et al. 2005). Resistant traditional cultivars are found in countries such as 
Thailand, Malaysia, Philippines, India, Indonesia and Vietnam where TLB has occurred for a long period of time. In the Pacific region CePaCT, Fiji maintains a collection of TLB-resistant varieties developed through breeding programmes in Hawaii, PNG and Samoa (Singh et al. 2012; Alexandra et al. 2020). In order to improve commercial taro for disease resistance, including TLB, and to increase genetic diversity, crossing commercial taro with TLB-resistant varieties are viable strategies which can prevent expansion of the disease in the region and mitigate adverse impacts on the livelihoods of taro growing farmers (Hunter et al. 2000).

Another significant aspect that cannot be overlooked is taro breeding for resistance to climatic extremes. Taro crop in the islands of Angaur, Peleliu and western coast of Babeldaob in Palau was completely destroyed in 1998 El Nino event which caused drought and severe water shortage in the country (Republic of Palau 2013). El Niño-induced drought conditions in Samoa caused a 5-8\% loss in taro production with a parallel 3-5\% increase in food imports (SPC, 2011). In the Cook Islands, taro production has been severely affected by climate change. Taro farming is adversely affected by drier environments on Mangaia, Aitutaki, Pukapuka and Mauke. Taro beetle (Papuana uniondis) causes extensive damage in countries such as PNG, Solomon Islands, Kiribati, Vanuatu and Fiji. Under the conditions of water stress, reduced tuberization, rate of photosynthesis and biomass, stomatal conductance and leaf area in taro have been reported, and the application of potassium or irrigation to sustain yields is recommended (Daryanto et al. 2016; Gouveia et al. 2020; Sahoo et al. 2018). Increased breeding activity of taro beetle (Papuana huebneri) is associated with prolonged dry spells (Freeman et al. 2012). Breeding for resistance to the taro beetle is complex, and should focus on elongated corms and increasing secondary metabolite levels to combat pest infestation. DNA analysis (fingerprinting) techniques should also be utilized to correctly identify beetle species present in the Pacific region. The good eating quality varieties of taro are susceptible to taro beetle and till date no resistant breeding line has been identified (Lebot et al. 2001). At present, the main challenges for plant breeders are the genetic sources for resistance/tolerance to leaf blight, viral diseases and beetle invasion in taro. Breeding for tolerance to soil salinity should be another key area of focus in the PICs particularly in low-lying coastal areas and atolls. Under moderate soil salinity, the margins of leaf blades turn yellow and as the salt concentration increases, dieback of leaf margins and even death of plants may occur (Miyasaka et al. 2002). In 2008, king tides and saltwater intrusion destroyed taro crop in around sixty per cent of atoll communities in the FSM. In Chukk, freshwater wetlands and lakes formerly used for irrigating taro beds have turned brackish over the last two decades, compromising taro productivity and food security (Fletcher and Richmond 2010). In Solomon Islands, taro production has been lowered with less tubers and lower yields in coastal areas across the years because of wave overtopping and warmer temperatures (GoSI 2008). In Pukapuka, Cook Islands, intense tropical cyclones in 2005 inundated taro plantations with saltwater and as a result taro could not be planted for a period of three years (FAO 2008a). These salinity conditions change in scale and interactions over a period and terrestrial area. Ensuring long-term adaptability of a variety depends on its degree of tolerance to multiple stresses in its natural environment. However, elucidating the physiological and molecular systems of these traits, their biochemical source, inheritance and efficient screening techniques are prerequisites to fast-track any breeding programme. Thus, breeding for saline environments requires consideration of multiple stress tolerance traits. In vitro screening for salinity tolerance of taro germplasm of PICs may be a suitable approach to identify the salt-tolerant donor cultivar. Although, the technique of plant breeding can generate sustained long-term benefits but it is labour intensive. It depends on well documented germplasms which may 
cause introgression of undesirable traits along with the preferred genes. Therefore, biotechnological approaches including molecular breeding and genetic engineering seem to be more attractive alternatives.

\subsubsection{Giant swamp taro}

Giant swamp taro (Cyrtosperma merkusii) is among the few subsistence crops that grow well under restrictive environmental conditions such as on atolls and swamps of Tuvalu and Kiribati. This root crop can remain underground for up to 30 or more years, and therefore provide nutrition during climatic exigencies (FAO 2010). The plant can withstand cyclones and storms with limited wind damage (Pobar et al. 2014; Taylor et al. 2019), and can also tolerate high soil moisture levels or flooding as long as it is not inundated by saltwater (Plucknett 1977; Thomas 2019). In the island of Nukulaelaethere, Tuvalu, during the 2010-2011 drought, there was a huge decline in the growth of giant swamp taro and some pulaka pits were devastated with rotting corms since prolonged dry spells increased soil salinity (Tekinene 2014) (Table 2). Swamp taro is salt susceptible and increased soil salinity can adversely affect growth. In Tuvalu, saltwater intrusion in pulaka pits particularly in areas frequented by king tides increases the salinity of freshwater lenses, causing yellowing and even rotting of tubers, often resulting in the abandonment of pits (Freeman et al. 2012; Iese et al. 2020; Webb 2006). Atolls where pit and swamp cultivation of taro is a common farming system, specifically face severe problems due to changes in water quality and saltwater intrusion increasing the salinity of freshwater lenses. This causes leaf chlorosis, wilting and ultimately death of the plants. Nevertheless, Rao et al. (2014) reported variation in salt tolerance among cultivars and recommended screening the $C$. merkusii gene pool in the Pacific to identify resilient varieties. Salt stress is a complex metabolic phenomenon and the adaptive processes in plants to tolerate saline stress are even now not well understood in a number of agriculturally important crops (Asraf and Harris 2004). Identifying the biochemical indicators of salt intrusion and salinity tolerance, will assist plant breeders to mine the useful genes of giant swamp taro. The burrowing nematode Radopholus similis has a wide host range in the Pacific including banana, coconut, taro, giant swamp taro (dela Cruz et al. 2005), and poses a severe risk to important food crops in the region. In Yap, FSM, corm rot of the giant swamp taro due to $R$. similis was reported by Murukesan et al. (2005). The rate of reproduction of $R$. similis is temperature sensitive with higher temperatures favouring rapid proliferation of the nematode (Jeger et al. 2017). Breeding for early maturing, in vitro screening for salt resistance and developing nematode-resistant varieties can be explored in the Pacific for ensuring food security in the atoll communities. This should be coupled with expediting plant diversity exchange and national, where appropriate regional crop improvement and breeding programs. Recurrent breeding is a simple procedure to palisade minor resistance genes for nematode resistance and develop a new population of resistant individuals. A major obstacle to breeding for resistance for nematode resistance has been the sporadic flowering of the edible cultivars, and limited genetic variability. However, genetic engineering and other biotechnology-based approaches to improvement are viable alternative methods.

\subsubsection{Sweet potato}

Sweet potato (Ipomea batatas) is a crop which has immense potential to meet demands for rapid availability of planting material and food production in the aftermath of natural 


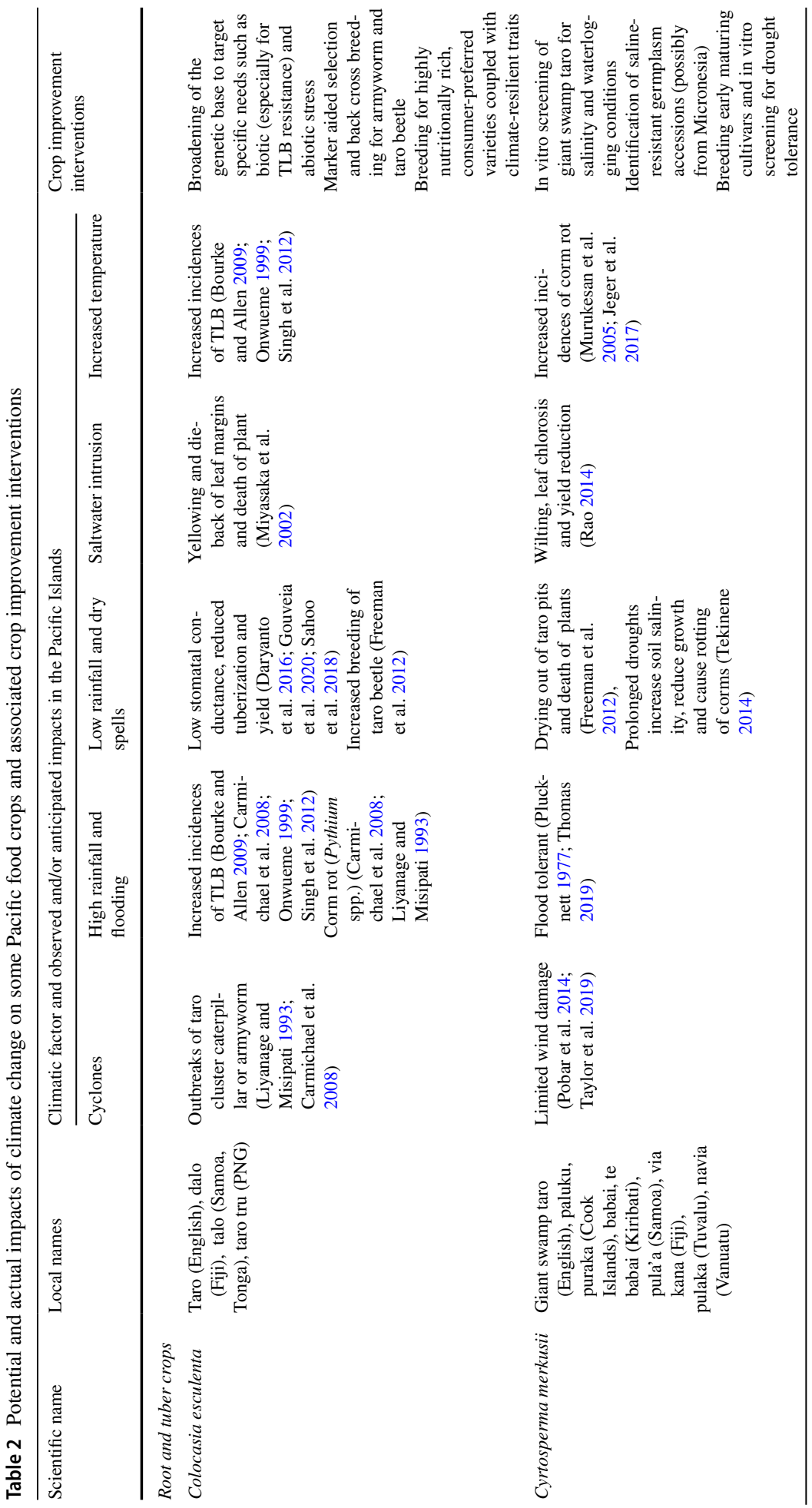




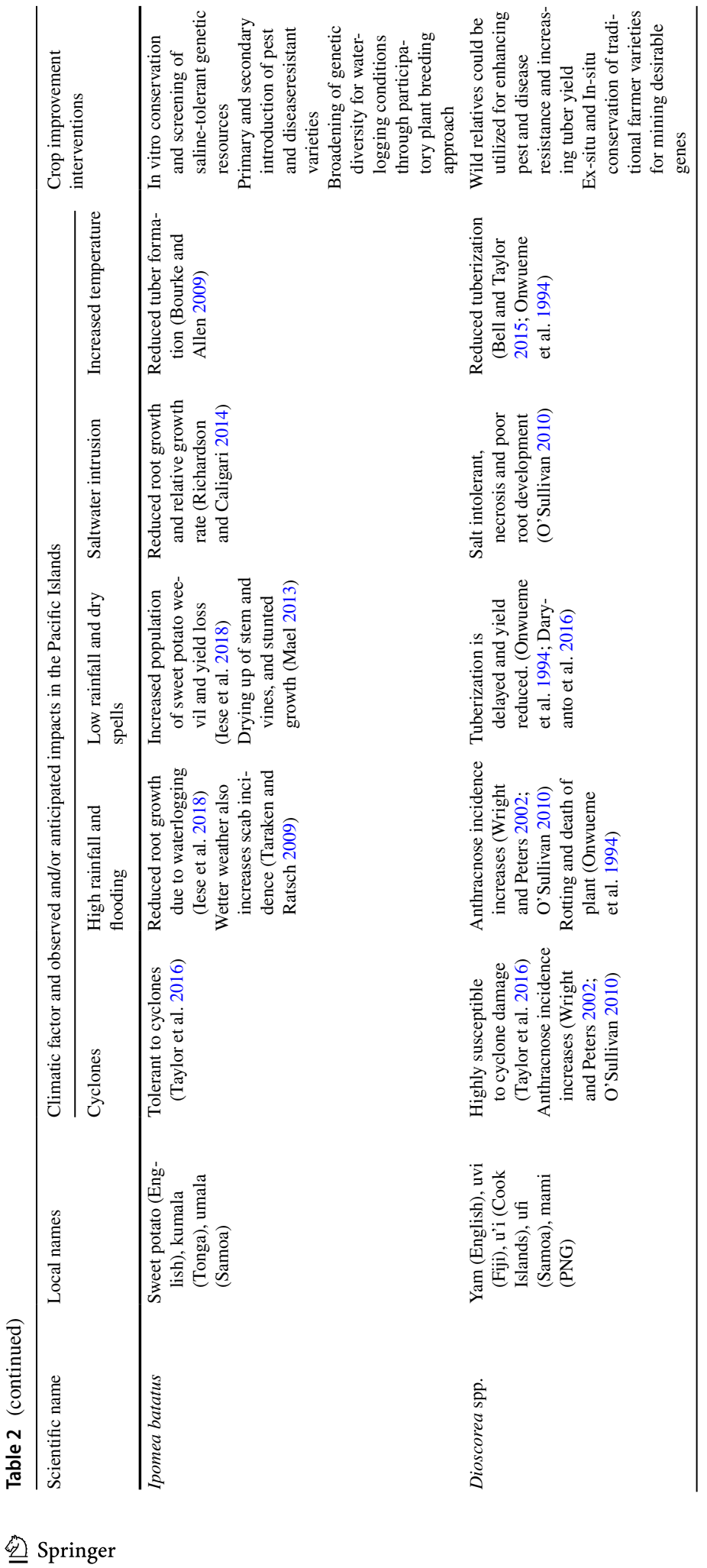




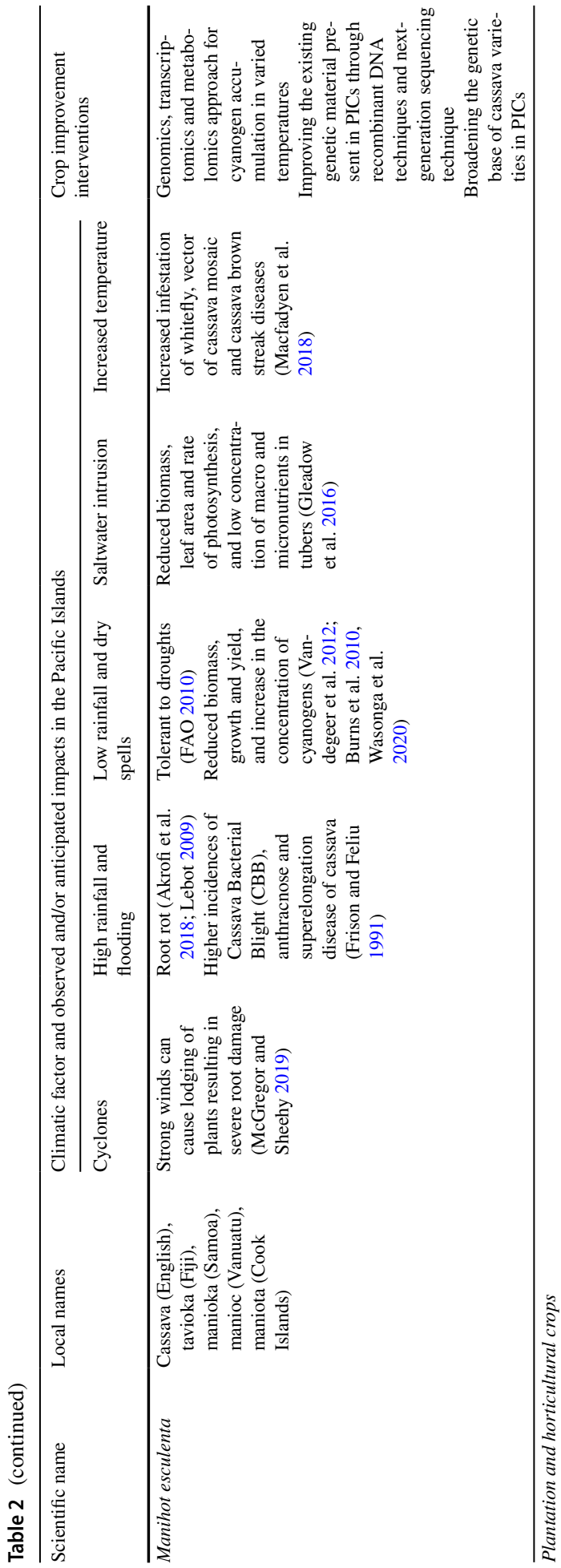




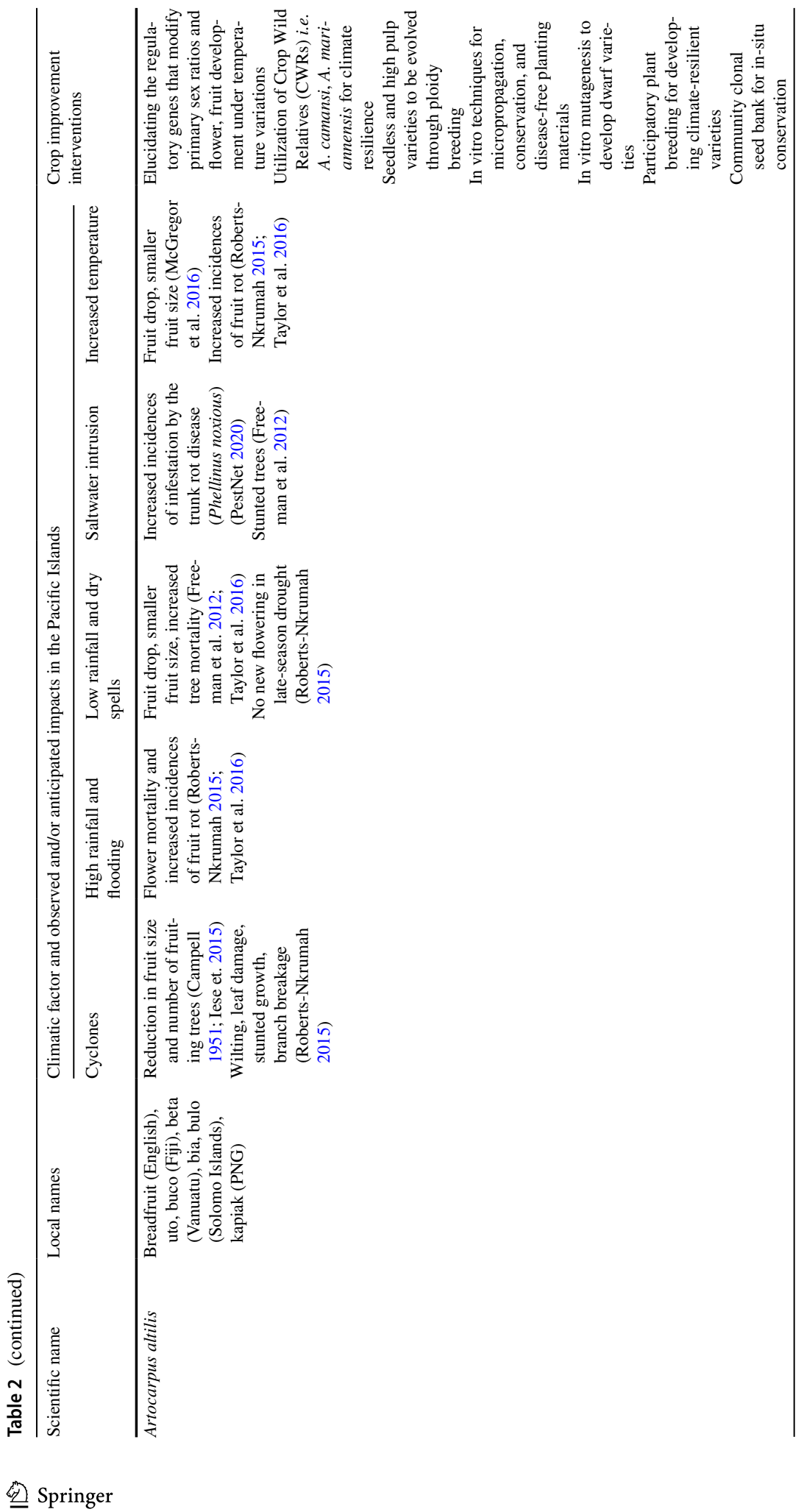




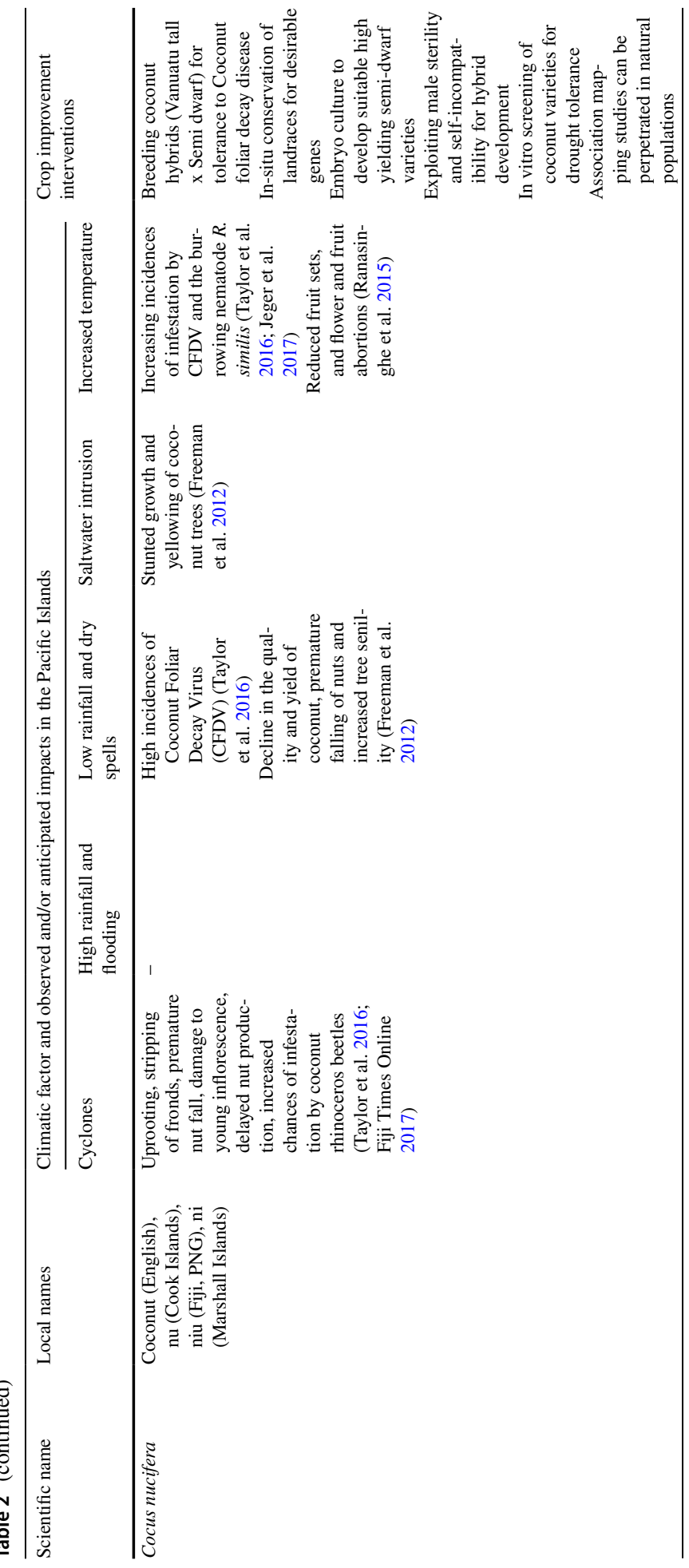




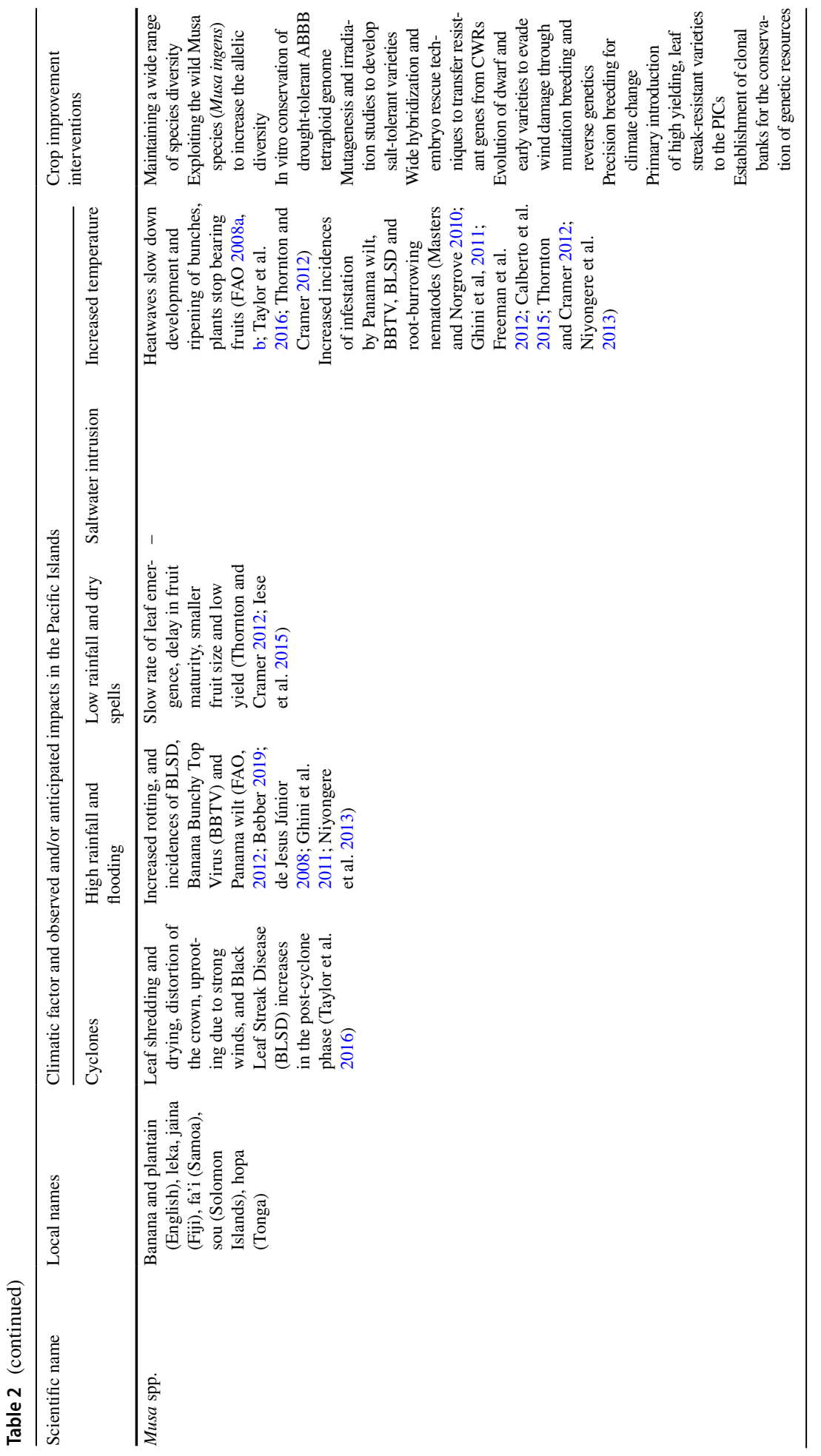

\section{Springer}




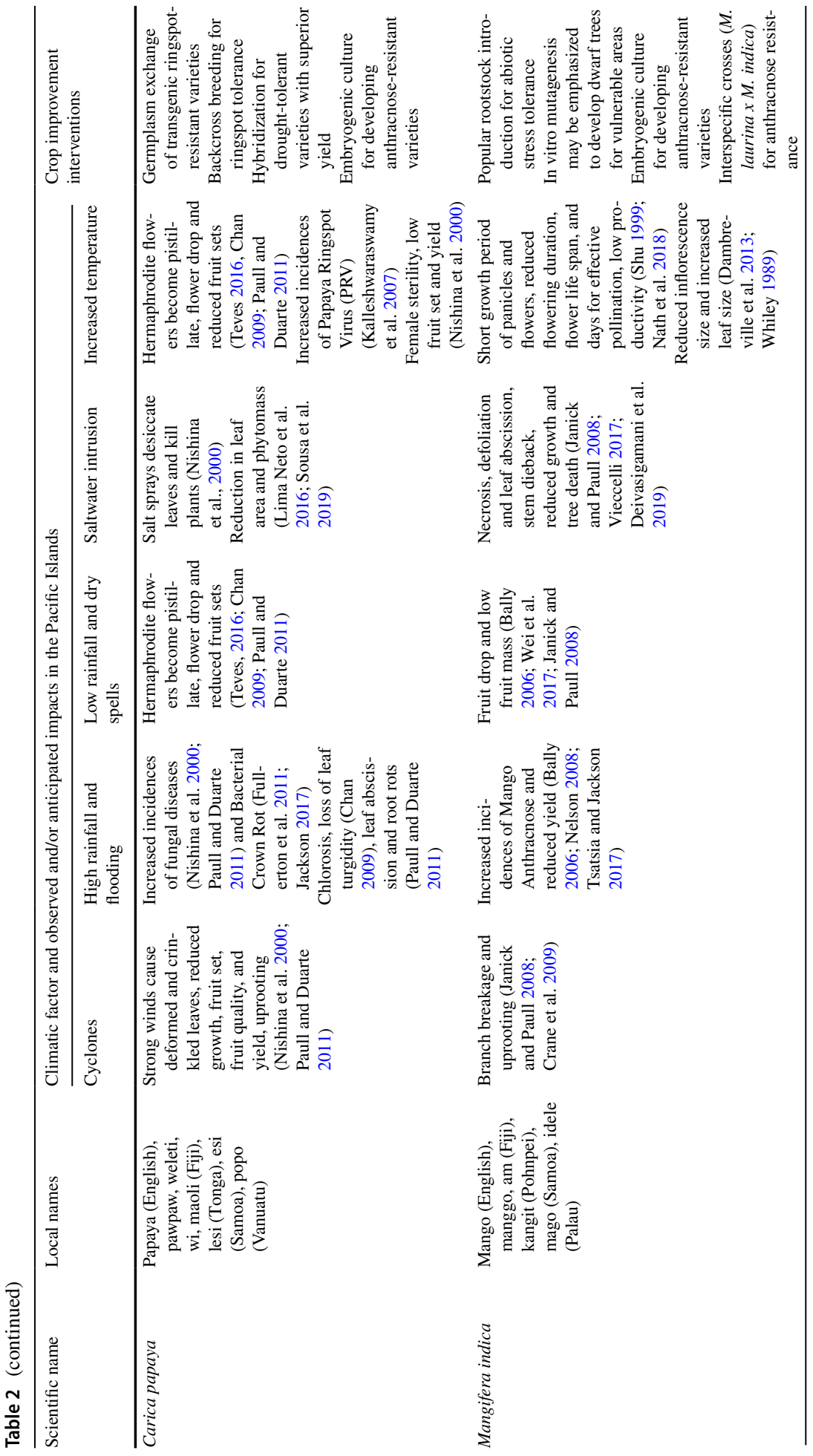




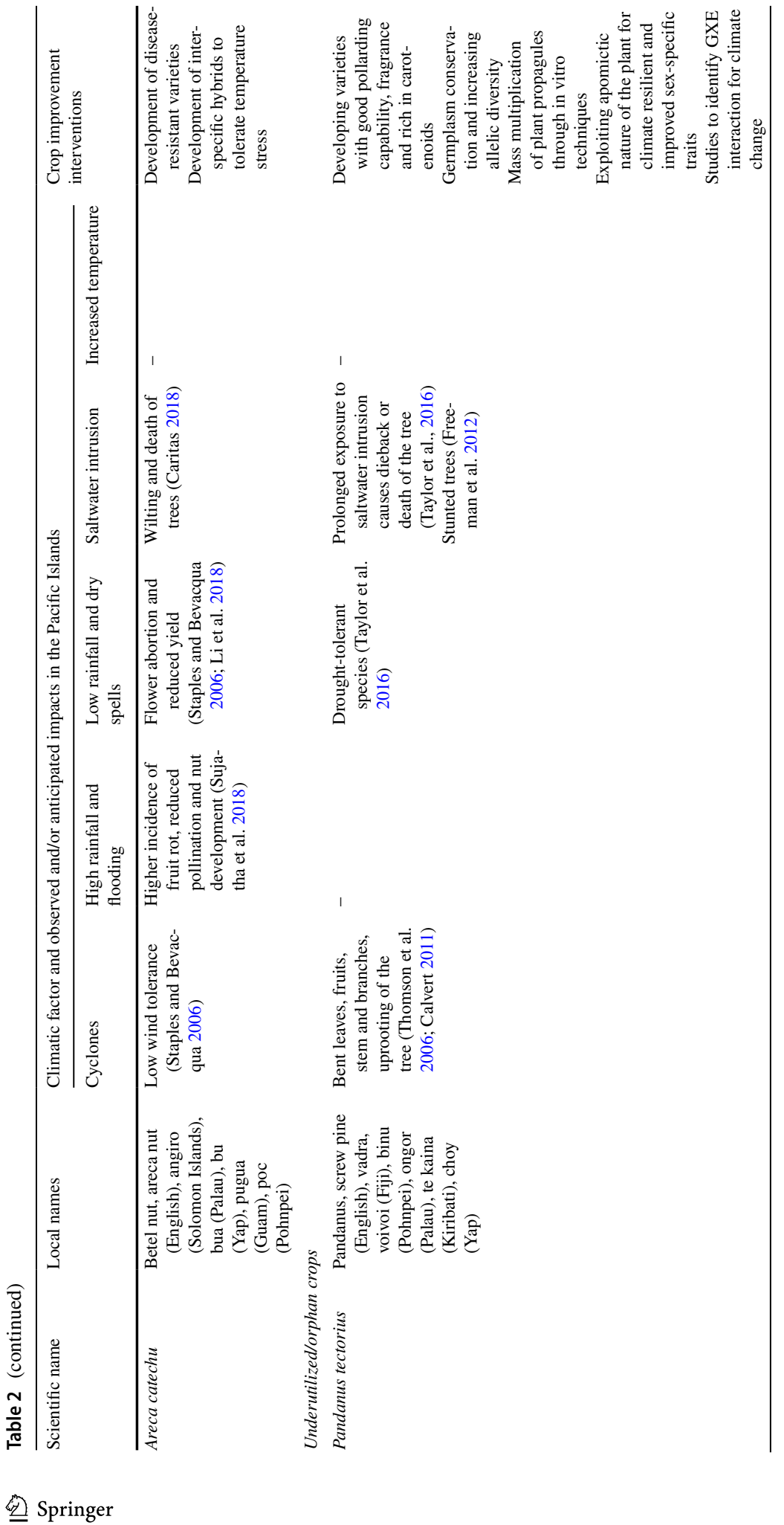




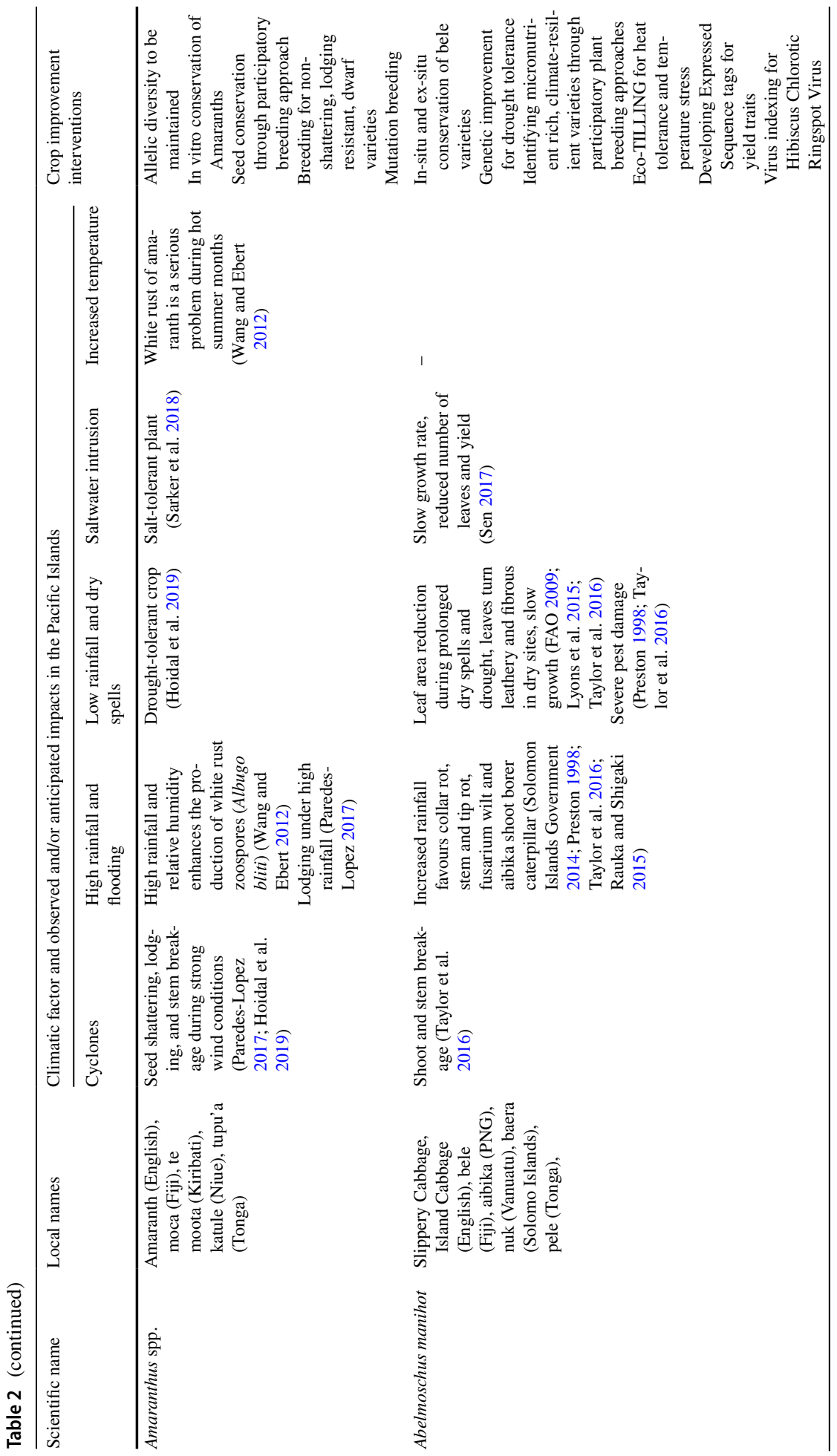




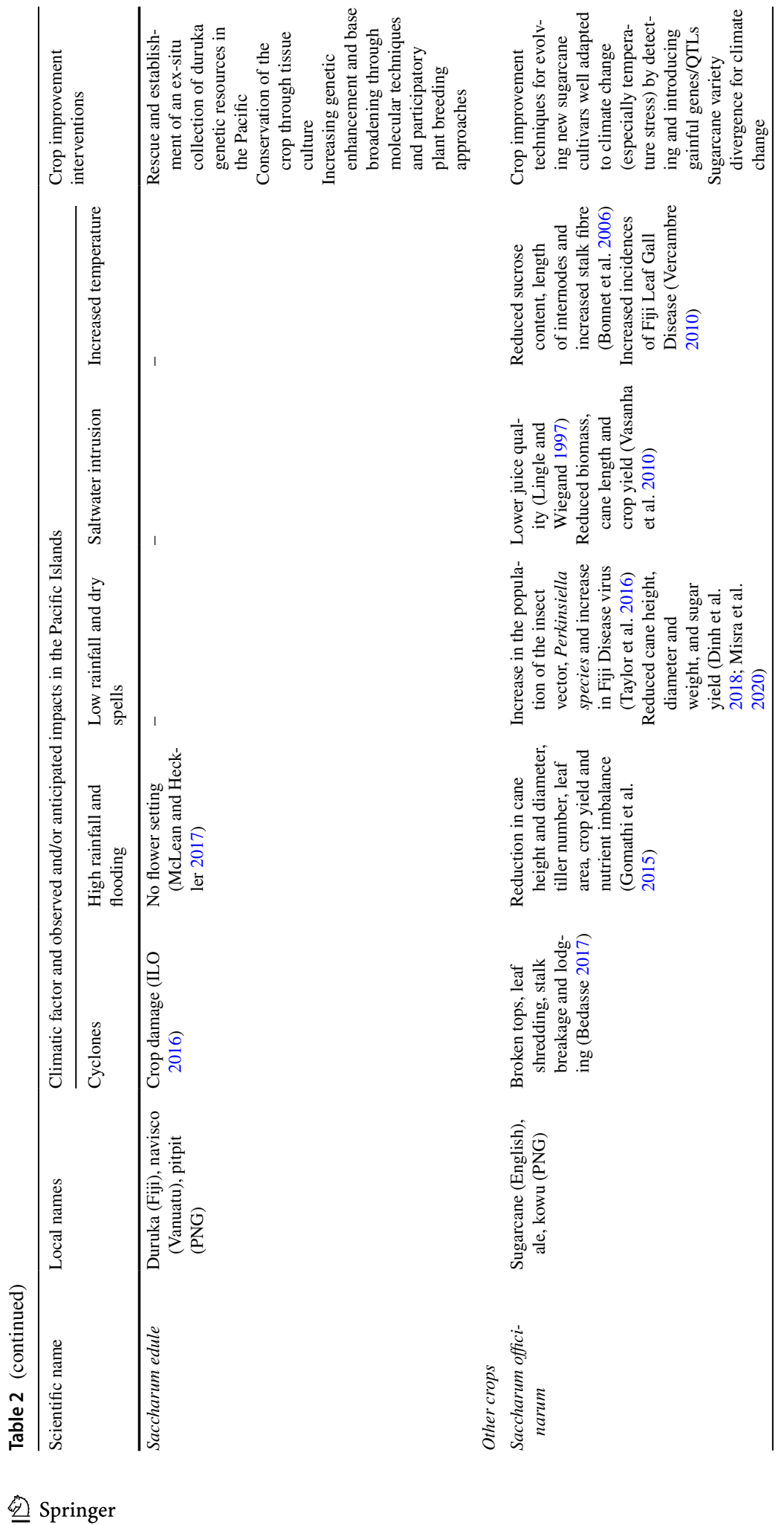




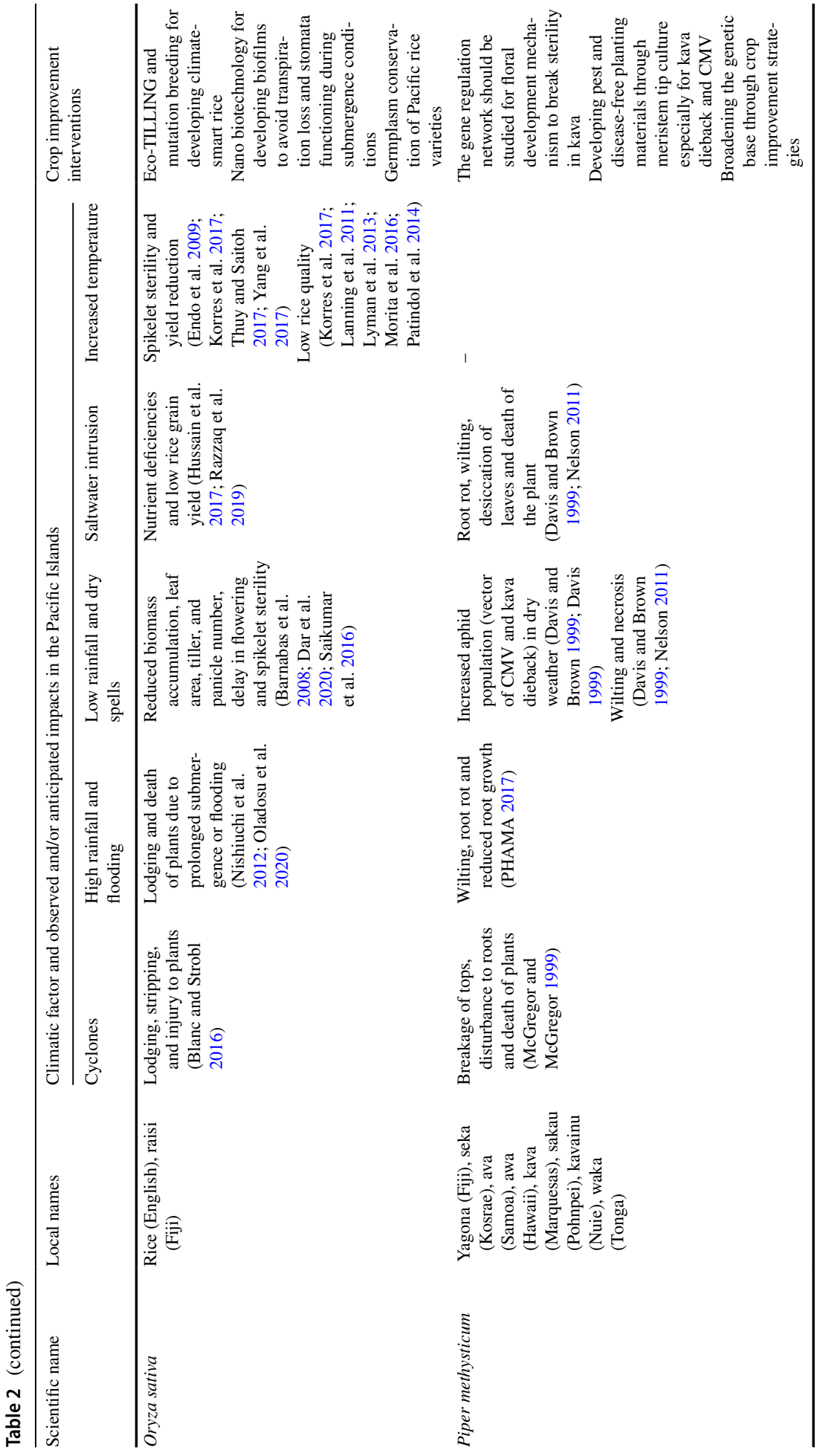


disasters. In Tonga and Fiji, after TC Ian and TC Winston, sweet potato cuttings were distributed to farmers for propagation as a recovery programme in the years 2014 and 2016 respectively (Iese et al. 2018). In Fiji, six varieties of have been identified for cultivation in extreme climatic conditions: Local Purple and Papua for dry zones, Kabara and Korolevu Red for wet conditions, and Carrot and Vulatolu for both dry and wet conditions. All these varieties have a maturity period of 4-6 months and are cyclone resistant (Ministry of Agriculture 2006), although the sweet potato variety Carrot is preferable in terms of nutritive value because of its high carotene content. Sweet potatoes are a good source of Vitamin $\mathrm{A}$ and $\mathrm{C}$, potassium, calcium, magnesium, phenolic acids and anthocyanins (Neela and Fanta 2019); however, the nutritive value is reduced due to climate change (Myers et al. 2014) triggering serious dietary deficiencies in human populations (Myers et al. 2015). All parts of the sweet potato plant, including leaves, stems and tuberous roots, can be used for human and animal consumption. Breeding programs should focus on enhancing the nutritive value of the crop and minimizing sugar concentration. This can simultaneously assist in addressing problems of Non-Communicable Diseases (NCDs) which are affecting island populations in the Pacific (Shah et al. 2018). In NARI, PNG, 1131 highland and 108 lowland accessions are conserved along with facilities for DNA fingerprinting and virus indexing. Around 36 accessions of sweet potato are conserved in the Koronivia, Dobuilevu and Seqaqa Agricultural Research Stations of the Ministry of Agriculture in Fiji. In the PICs however, a major limitation is insufficient research exploring the impacts of climate change on sweet potato production. Nevertheless, some of the existing studies indicate that droughts have not just reduced yield but also increased incidences of weevil (Cylas formicarius) infestation, whereas water logging in some areas has reduced root growth (Iese et al. 2018). Breeding varieties with large stem and small leaves may allow the crop to withstand dry conditions by evading transpiration loss. In Emae Island, Vanuatu, droughts have become more frequent, and have adversely affected sweet potato cultivation, resulting in drying up of stem and vines, and stunted growth (Mael 2013) (Table 2). Wet climate also favours rapid development of sweet potato scab (Elsinoe batatas), widespread in the Pacific including Fiji, Vanuatu, Tonga, PNG, Solomon Islands, FSM, Palau, Niue and Cook Islands (Taraken and Ratsch 2009). Soil salinity also has adverse effects on sweet potato with reduction in relative growth rate and root growth as reported by Richardson and Caligari (2014). The development of resistant cultivars can improve the adaptive capacity of sweet potato farming communities in the region. In PNG where sweet potato is an important staple, average temperatures have increased in both lowlands and highlands since the mid-1970s. Tuber formation in sweet potato is significantly reduced at temperatures above $34{ }^{\circ} \mathrm{C}$. Therefore in the lowlands where current maximum temperatures are around $32{ }^{\circ} \mathrm{C}$, any further increase in temperature could significantly compromise yields (Bourke and Allen 2009). Under such circumstances, yields may however be sustained through allele mining, identifying transcriptional factors, and Genome Wide Association Studies (GWAS) for abiotic and biotic stress (Kumar et al. 2010; Kang et al. 2019; Okada et al. 2019).

\subsubsection{Yam}

In the South Pacific, the two most important cultivated species are Dioscorea alata and D. esculenta (Kenyon et al. 2008), while D. nummularia, D. transversa and D. pentaphylla occur in the wild (Taylor et al. 2016). Yam production in Fiji has decreased in some areas due to shifting precipitation patterns and the crop has become more labour intensive 
(McLean and Heckler 2017). Among root crops, yams are considered climate resilient. However, cultivated yams are vulnerable to cyclones since strong winds may break trellises used for support, resulting in rotten tubers if damaged prior to maturity (Taylor et al. 2016). Wild yams are however, more resilient to cyclone damage since they possess strong and fibrous vines which use forest trees for support (Taylor et al. 2016). Anthracnose caused by Colletotrichum gloeosporioides is the most serious foliar disease of yams which causes premature dieback, the problem being more severe in monocropping systems. Under conditions of high rainfall and humidity, the incidence of anthracnose increases since spores are spread by rainsplash. The post-cyclone period also increases the severity of an anthracnose outbreak in susceptible yam varieties, since large production of spores on leaf spots is accompanied with rapid transfer through rainwater to adjacent plants. Prolonged waterlogging due to high rainfall also increases the probability of rotten tubers and subsequent death of the plant (Onwueme et al. 1994). In Vanuatu, anthracnose-resistant D. alata hybrids were developed as a pioneering work by employing tetraploid fertility combined with other target traits (Lebot et al. 2019).

The stage of crop development also has an important role to play since young foliage is more susceptible to infection (Wright and Peters 2002). It is likely that nutritional deficiencies also exacerbate the severity of the disease in yam (O'Sullivan 2010). The plant can survive in low rainfall conditions because of long dormancy period (Ile et al. 2006), vigorous root development soon after sprouting to capture the available soil moisture, xerophytic adaptations such as waxy bloom on the stem to reduce transpiration, and tapping the parent plant for moisture (Onwueme et al. 1994). A meta-analysis by Daryanto et al. (2016), to assess the effects of drought on root and tuber production, revealed that yams exhibit relatively high drought tolerance in the initial phases of planting. When the young plant has no leaves and therefore low transpiration and potential water loss, it can tap the mother tuber to meet its moisture demands, however if the drought persists, tuberization is delayed and the yield declines. Srivastava et al. (2012) estimated the impact of climate change on yam production in the sub-humid savanna zone of West Africa. Their study indicated a projected decline in yam production by 18-33\% over the period 2041-2050 wherein low rainfall would increase drought stress and limit the mineralization of soil organic matter causing nitrogen deficiency.

Yams are sensitive to soil salinity, and salt-affected plants exhibit necrosis and improper root development. In areas where salinity is a severe problem, planting salt-tolerant trees to control groundwater rise, addition of organic matter and building raised beds is recommended (O'Sullivan 2010). Optimum temperature for yams is between 25 and $30{ }^{\circ} \mathrm{C}$. High temperatures retard tuber growth because of relatively high vegetative shoot growth and rate of respiration (Bell and Taylor 2015; Onwueme et al. 1994). CePaCT is conserving 330 accessions as a unique collection of in vitro yam germplasm from the Pacific region. This can be easily accessed by breeders in the Pacific region.

Development of core sub-sets of underutilized germplasm of biotic resistance, abiotic stress tolerance and enhanced nutritional quality, offers an opportunity to mine novel alleles. The genus however has a number of species in different ploidy levels, which facilitates the development of resistant hybrids through breeding techniques such as controlled pollination for genetic evaluation. Moreover, confirming ploidy level and hybridity through molecular markers may overwhelm the minimum success rate and facilitate the development of well-organized yam breeding programmes. The detection of tetraploid $(2 n=80)$ with a significant level of sexual fertility in D. alata has launched new avenues in polyploidy breeding using conventional hybridization (Arnau et al., 2009). Furthermore, seed quality of yam can be improved by Semi-Autotrophic Hydroponic (SAH) technique to 
facilitate early generation testing thereby reducing the time of breeding cycles and ensuring sustainable seed chain (Pelemo et al. 2019). The availability of technical expertize can play a pivotal role in the identification of female plants and flowering induction for yam improvement. Some technical expertize however is available in the Ministry of Agriculture, Koronivia Research Station and SPC in Fiji, NARI in PNG, VARTC in Vanuatu, and the University of South Pacific's Alafua Campus in Samoa.

\subsubsection{Cassava}

Cassava (Manihot esculenta) is vulnerable to cyclone damage as observed in Vanuatu where it is a supplementary food crop except in areas with infertile soils (Sardos et al. 2008). Strong winds can cause lodging of plants inducing root rot and loss of crop. Farmers anticipating cyclones in the Pacific are advised to cut off the stems above the soil surface to minimize root damage (McGregor and Sheehy 2019). Cassava is intolerant to flooding and waterlogging which predispose the tubers to root rot causing dieback of terminal shoots and wilting. Root rots can impair crop productivity declining yields by up to $80 \%$ in waterlogged soil or in plots close to drainage ditches (Akrofi et al. 2018; Lebot 2009). High rainfall increases chances of infestation by Xanthomonas campestris pv. manihotis which causes Cassava Bacterial Blight (CBB) resulting in wilting, leaf fall, stem rot and dieback. Cassava anthracnose (Colletotrichum gloeosporioides) usually occurs in cassava growing areas with annual rainfall above $900 \mathrm{~mm}$; spore dispersal occurs through wind driven rain. Sphaceloma manihotico causes the super elongation disease of cassava which is more severe in the rainy season due to spore dispersal by rain splash. This disease has been recorded from Cook Islands where infected plants do not have elongated stems but develop distorted leaves and scab-like lesions (Frison and Feliu 1991). Cassava is drought tolerant and can be cultivated in semi-arid regions with an annual rainfall as low as $500 \mathrm{~mm}$ (FAO 2010). However in the tropics, the crop may experience intermittent water stress which reduces growth and yield along with an increase in the cyanogen content particularly during storage root initiation posing greater threat to food and nutritional security (Vandegeer et al., 2012). Prolonged exposure to dry spells during tuberization can lower yields by 32-60\% (Boansi 2017). Decline in yield is attributed to reduced stomatal conductance, photosynthesis, number of leaves and leaf area, and is more pronounced during the first 5 months of planting (Burns et al. 2010; Wasonga et al. 2020). Cyanide concentration is around three times higher during drought years than in years with normal rainfall (Burns et al. 2010). An increase in eCO2 increases the concentration of another cyanogen, linamarin in cassava tubers. Although the cyanogen concentration in cassava varieties of the PICs is relatively low but it is likely that drought and eCO2 could raise cyanogen levels significantly (Taylor et al. 2016). Gleadow et al. (2016) reported sensitivity of cassava to low to moderate levels of salt in soil particularly during early stages of development. Under conditions of salt stress, reduced concentration of macro and micro nutrients in tubers, along with reduced biomass, leaf area and rate of photosynthesis was also reported in the same study. An increase in temperature up to $30-33{ }^{\circ} \mathrm{C}$ can increase the population of whitefly (Bemesia tabaci), though beyond this temperature the rate of multiplication decreases. B. tabaci causes direct feeding damage and secretes sugary honeydew which attracts sooty moulds impairing photosynthesis and respiration. It also acts as a vector of cassava mosaic and cassava brown streak diseases causing significant loss of productivity (Macfadyen et al. 2018). Boansi (2017) studied the impacts of climate change on cassava yields in Togo; a leader in cassava production during late 1960s to early 1980s 
in West and Central African sub-region, the country suffered a massive decline in cassava productivity (63.49\%) between 1964 and 2013. The study reported a decline in cassava yields with an increase in within lean season rainfall variability and mean temperature, while main season rainfall and mean temperature have favourable effects on yield. There is a need to conduct studies assessing the impacts of climate change on cassava production in the Pacific. A broad gamut of breeding aims incorporating some key traits like high fresh weight and dry matter content are required to sustain yields. In order to avoid yield losses due to pests and diseases, in vitro techniques like meristem culture and somatic embryogenesis may be applied to supply high quality planting materials to farmers (Fregene et al. 2002). Polyploidization of interspecific hybrids and utilizing its apomictic nature in cassava may also result in the synthesis of new cultivars (Nassar et al. 2010). Particularly in Pacific, cassava breeding programmes should focus on improved genotypes for good eating quality, higher nutritional content, and increased storage time along with dwarf varieties to avoid lodging due to high winds and salt tolerance under saltwater intrusion. Ceballos et al. (2012) opined that participatory breeding techniques are suitable for regions where cassava plays a major role in food and nutritional security, and is raised in low-input settings and marginal environments.

\subsection{Plantation and horticultural crops}

Food production in the Pacific Islands was based on the incorporation of trees in farming systems; a tradition intricately linked with the historical and cultural identity of island people (Bell and Taylor 2015, Nevile 2014). Agroforestry in the Pacific as in other parts of the world has great significance in terms of food security and enhancing the resilience of communities to climate change (Mbow et al. 2014). Tree crops such as breadfruit, coconut, banana and plantains, papaya, mango and betelnut incorporated with staple ground crops in homegardens, fallows and garden plots are a common feature of the PICs. However, despite adverse impacts of climate change on plantation and horticultural crops evident in the region, insufficient research ascertaining the specific nature of these impacts is a key limitation. Vigorous efforts on screening and conservation of climate-resilient genotypes for tree crops, is also needed for efficient adaptation of food production systems to the changing climate.

\subsubsection{Breadfruit}

Although breadfruit (Artocarpus altilis) is susceptible to damage by strong winds (Bell et al. 2016) which is usually confined to outer branches, trees rarely get uprooted during tropical storms (Taylor et al. 2016). Persistent wind however, may case leaf damage, wilting, stunted growth and a lopsided canopy as a result of greater growth on the sheltered side, whereas hurricane force winds generally cause branch breakage (Roberts-Nkrumah, 2015). High survival rates of breadfruit were reported post-TC Winston in Fiji and Cyclone Ofa in Samoa (McGregor and Sheehy, 2019). Conversely, when Cyclone Evan struck Samoa in 1990, it caused massive destruction to the breadfruit crop of the country (Government of Samoa 2013). In 1979 Cyclone Meli damaged the entire breadfruit crop in the island of Cicia in Fiji's Lau group (Downing et al. 2002), and over the years there has been a reduction in the number of fruiting trees due to frequent incidences of tropical cyclones (Ragone, 2011). Iese et al., 2015 reported that in Bellona atoll, Solomon Islands while increased rainfall damaged the flowers of breadfruit, a reduction in fruit size was 
attributed to cyclones. Increasing incidences of fruit rot by Phytophthora palmivora and Glomerella cingulata occur with an increase in rainfall, relative humidity and temperature (Roberts-Nkrumah 2015; Taylor et al. 2016). In Kiribati, increased length and severity of droughts has caused a decline in the quantity and quality of breadfruits and increased tree mortality (Wairiu et al. 2012; Freeman et al. 2012). A late-season drought may cause loss of fruits close to maturity with no new flowering in the season (Roberts-Nkrumah 2015). On the other hand, sea level rise and saltwater intrusion has stunted tree growth (Freeman et al. 2012) and increased the susceptibility of breadfruit trees to the brown root rot disease caused by Phellinus noxius, a soil inhabiting fungi, the problem being more severe in the seeded than the seedless varieties (PestNet 2020). A study by Lee et al. (2008), to assess the impact of the December 26, 2004, Tsunami and consequent salinization of soil profiles and groundwater wells on fruit trees in Maldives revealed that breadfruit has moderate tolerance to soil salinity. The trees initially suffered severe damage in the form of leaf scorch by salts and loss of leaves, though later with the commencement of the first monsoon after the tsunami, some of the trees recovered and developed new shoots. The morphological diversity of breadfruit cultivars in the Pacific provides a great opportunity to screen and develop dwarf varieties which are resistant to wind damage (Zhou et al. 2014). Recently Zhou and Underhill (2019) identified a Marang root stock with traits of dwarfness in breadfruit. The foreground selection of root stocks with salinity and drought tolerance, and introgression with dwarf genes may be a viable approach to adapt breadfruit cultivars to climate change in the Pacific. Indigenous communities in Fiji believe breadfruit bears more fruit around 10 days before a cyclone which indicates its potential utilization as a cyclone indicator crop. However, the environmental factors related to breadfruit development and temperature stress on breadfruit reproduction biology are yet to be explored. Breadfruit genetic resources of the Pacific region should be conserved by in vitro conservation techniques and crop improvement programmes to mitigate impacts of climate change on food security of island communities.

\subsubsection{Coconut}

Cyclones may uproot entire trees particularly young and senile palms; severe damage is encumbered in countries such as Fiji, Vanuatu and Samoa, where extensive areas of coconut plantations have turned senile. Strong winds may cause stripping of fronds, premature nut fall, damaged inflorescence and delayed nut production (Taylor et al. 2016). In February 2005, an abrupt ENSO phase shift triggered 4 intense tropical cyclones, Meena, Nancy, Olaf, and Percy, category $\geq 3$ that caused massive devastation in the Cook Islands (Umeyama 2012). An assessment of the extent of damage caused by Meena, Nancy and Olaf to coconut plantations revealed that around 60-70\% of the trees were damaged with severe stripping of fronds, loss of nuts and uprooting. Akitua and Samade Bars faced the worst damage with $90 \%$ of the coastline eroded, resulting in either fallen trees or exposed roots (FAO 2008a). Cyclone Anne in 1977 and Cyclone Bob in 1978 were responsible for widespread damage to coconuts in Fiji (Downing et al. 2002). Cyclone Ofa and Val in 1990 and 1991 respectively damaged a fifth of the coconut trees in Samoa, with similar observations in 2012 due to TC Evan (Taylor et al. 2016). Cyclones were responsible for the demise of the copra industry in Bellona, Solomon Islands (Mertz et al. 2012; Iese et al. 2015). A marked increase in the incidences of attack by the rhinoceros beetle in Fiji was observed post-Cyclone Winston; farmers were advised to dispose any dead and decaying trees, and vegetation to control the 
spread of the pests (Fiji Times Online 2017). This incursion may be due to a new strain of CRB, the CRB-Guam biotype. Recent analysis of DNA from an ongoing survey has detected CRB-Guam in Guam, Hawaii, Palau, Port Moresby (PNG) and Honiara (Solomon Islands). Thus current invasions in the Pacific involve the CRB-Guam biotype and it is expected that these populations are tolerant to all available isolates of Oryctes rhinoceros nudivirus (OrNV), the biological control agent of choice for this pest

(Marshall et al. 2016) (Table 2). Coconuts can survive water stress as evident from their ability to grow in atoll environment, attributed to the production of homorhizic roots for continuous extraction of water and nutrients, and high protoplasmic tolerance (Gomes and Prado 2007). These characteristics enhance the WUE of palms which varies among varieties and further among ecotypes of the same variety (Hebbar et al. 2017). However, prolonged drought retards nut production (McGregor and McGregor 1999), as observed during the 2009-2010 dry spell in Kiribati. The drought deteriorated fruit quality, lowered production, triggered premature falling of fruits and accelerated the senility of trees. In Vanuatu, higher temperatures and low rainfall (Taylor et al. 2016) are factors which could exacerbate problems of Coconut Foliar Decay Disease (CFDD) caused by Coconut Foliar Decay Virus (CFDV), a virus endemic to the island and transmitted by Myndus taffini. This vector breeds in the roots of the beach hibiscus, a plant abundant throughout the Pacific (Hibiscus tiliaceus), which increases possibilities of widespread infestation if left uncontrolled under a changing climatic scenario (Labouisse et al. 2011; Wefels et al. 2015). In Kiribati, rising sea levels and saltwater intrusion have increased soil salinity and stunted tree growth particularly in coastal parts of the island. Similarly, in Tuvalu rising sea levels are inducing yellowing of coconut palms in low-lying areas and beach erosion due to tidal waves is causing the palms to fall (Freeman et al. 2012). The occurrence of a new pest, the coconut scale (Aspidiotus destructus) has been recently reported in Kiribati and Tuvalu (Freeman et al. 2012). High temperatures are also conducive for rapid multiplication of the burrowing nematode $R$. similis (Jeger et al. 2017). Some authors (Hebbar et al. 2013; Kumar and Aggarwal 2013) assert that high temperature can affect coconut production either positively or negatively, depending upon the geographical area under consideration and the phase of development. Increased sensitivity of plants to high temperatures is reported during the reproductive than vegetative phase (Hinojosa et al. 2018). In low to mid-latitudes, heat stress may reduce fruit sets, and induce flower and fruit abortions due to pollen germination at high temperatures, way above the optimum range $25-30{ }^{\circ} \mathrm{C}$ (Ranasinghe et al. 2015). Very high temperatures may inhibit photosynthesis and accelerate respiratory losses, promote leaf senescence, pollen sterility and immature nut fall, thereby causing severe losses in yield and productivity (Kumar and Aggarwal 2013). Beneficial effects are anticipated in cold limited high altitudes where an increase in minimum and maximum temperature may accelerate the rate of leaf and inflorescence emergence respectively. Elevated $\mathrm{CO}_{2}$ concentration is likely to benefit coconut productivity since it is a C3 crop. Using the simulation model InfoCrop-COCONUT, Kumar and Aggarwal, 2013, assessed the impacts of climate change on coconut production in India. They projected that elevated atmospheric $\mathrm{CO}_{2}$ concentration and temperature rise, will increase coconut productivity, wherein adverse impacts of high temperature will be offset by favourable influence of $\mathrm{CO}_{2}$ fertilization. In Sri Lanka where coconut is a major plantation crop, Pathmeswaran et al. (2018) found that the impact of extreme weather events on coconut productivity varied with the climatic zone in consideration. High $\mathrm{T}_{\max }$ events during the first four months after flowering adversely affected coconut 
productivity in the dry zone, and high rainfall events reduced coconut productivity in both the dry and intermediate zones, whereas no impact was observed in the wet zone.

Considering the high vulnerability of the coconut industry to climate change, it is critical that coconut cultivars resistant to heat stress, high rainfall, insects, pests and diseases are developed to enhance the resilience of coconut production. Screening of genotypes therefore becomes important to identify resistant cultivars. Although coconut is monotypic, substantial phenotypic variation in plant stature, leaf morphology, nut shape, and pest and disease resistance is present in the coconut germplasm. The Pacific region has high genetic diversity of coconuts including some rare forms. Niu 'utongau (Sweet Husk), a rare and threatened traditional coconut variety with tender, sweet and edible husk in unripe condition, is found in quantity only in the small coral islet Onoiki in the Ha'apai group of Tonga (Bourdeix et al. 2013). Such endemic genotypes are threatened by climate change and their genetic conservation is of urgent importance. However, conservation of coconut genetic resources through field genebanks is cost prohibitive, since at least half a hectare is needed for a single genotype. Moreover, the nuts cannot be stored due to their recalcitrant nature, hence in vitro conservation and cryopreservation of coconut genetic resources becomes very important. Coconut improvement programmes generally require at least 7-8 ha for laying out trails, which is a major bottleneck in ensuring a secure environment. Furthermore, evolving hybrids requires artificial pollination which is an expensive technique for coconuts and maintenance of isolated seed gardens is expensive. Polymotu, an ancient Polynesian concept is being advocated for conserving coconut diversity in the Pacific. This concept utilizes the geographical isolation of special sites for the conservation and propagation of individual coconut varieties and is considered a suitable alternative to costly cross pollination (Bourdeix et al. 2011). As a cost-effective technique, identification of male sterile or self-incompatible lines is also recommended since till date male sterile lines are not available.

\subsubsection{Banana and plantain}

In 2014, TC Ian destroyed almost all the banana and plantain crop in Ha'apai, Tonga (FAO 2014). Prolonged drought following the 1997/1998 El Nino in the Pacific resulted in either severe stress or mortality of 50 per cent of the banana crop in Pohnpei (WHO 2000). In Bellona, Solomon Islands, prolonged rainfall is reported to enhance rotting in banana and prolonged drought has been responsible for delay in fruit maturity (Iese et al. 2015). Slow rate of leaf emergence, smaller bunch size and reduced yield are a result of soil moisture deficit (Thornton and Cramer 2012). Using the Crop Water Assessment Tool (CROPWAT) of FAO to estimate the impact of climatic variability on banana yields across Uganda, Sabiiti et al. (2016), reported yield reduction up to $46 \%$ due to soil moisture deficit over the period 1971-2009. In the East African highlands drought is a serious constraint to banana production with every $100 \mathrm{~mm}$ decrease in rainfall corresponding to an average $1.5-3.1 \mathrm{~kg}$ reduction in absolute maximum bunch weight (van Asten et al. 2011). With a strong focus on developing disease-resistant cultivars in most banana-breeding programmes, evolving drought-resistant varieties has so far been inadequate (Ravi et al. 2013). A recent study by Varma and Bebber (2019) on climate-yield relationships in banana observed that climate change in the recent past has been favourable for banana cultivation with an average global yield increase of 1.37 tha $^{-1}$ since 1961, though yield gains would disappear in the future reducing by 2050 to 0.59 tha $^{-1}$ and 0.19 tha $^{-1}$ under RCP 4.5 and 8.5 respectively. Among the leaf diseases of banana, the most devastating is BLSD caused by the fungal pathogen 
Pseudocercospora fijiensis which thrives in warm and moist conditions that are also ideal for banana production (Bebber 2019). The disease typically found at relatively low and warm elevations, was first identified in Sigatoka Valley, Viti Levu, Fiji in 1963, and ever since, it has spread to most banana producing areas in the world, adapting at cooler, higher elevations (Arzanlou et al. 2007). The migration of BLSD towards highlands is causing the replacement of the less aggressive Yellow Sigatoka (P. musicola). In Costa Rica BLSD migrated from an elevation of 900 to $1500 \mathrm{~m}$ over the period 1985-1990, and in Columbia from 1500 to 1600 m over 1988-1991 (Guzmán 2019). It is expected that an increase in rainfall will increase the incidences of infestation by BLSD (FAO 2012; Bebber 2019; de Jesus Júnior, 2008; Ghini et al., 2011; Taylor et al. 2016). Severe BLSD infestation generally occurs two weeks after a storm or after a period of heavy rainfall, due to increased moisture availability (FAO 2012). The post-cyclone period also creates conducive conditions for rapid release of BLSD conidia (Taylor et al. 2016). Disease transmission depends on the weather conditions, whilst ascospores are wind borne and the principal means of dispersal over long distances within the infected plantation and to new areas, conidia are dispersed by rain water locally (FAO 2012; Bebber 2019). Response to Relative Humidity $(\mathrm{RH})$ differs between ascospores that germinate only at $\mathrm{RH}>98 \%$ and conidia which germinate at RH ranging between 88 and 100\% (Calberto et al. 2015). Calberto et al. 2015 projected the impact of climate change on banana production in six key banana growing areas of Latin America, Africa and Asia for 2030, 2050 and 2070. All six sites experienced increase in temperature which is likely to increase BLSD infestation due to rapid spore germination by 2050 and 2070, though this infestation would only occur in the presence of leaf wetness. Increased cases of infestation by BLSD have been reported in Vanuatu due to rising temperatures (Freeman et al. 2012). Bebber (2019) reported that since 1960s, BLSD infection risk in banana growing parts of the Caribbean and Latin America has increased by a median of $44.2 \%$ due to higher temperature and canopy wetness. Ghini et al. (2011) reported that rising temperature and drought can increase invasion by Fusarium oxysporum f.sp. cubense which causes Panama disease of banana. Transmitted by the aphid vector Pentalonia, Banana Bunchy Top Virus (BBTV) is the most severe viral disease of banana and plantains in Asia, Africa and the South Pacific. Niyongere et al. (2013) studied the epidemiology of BBTV in Burundi, Africa, and found that high temperature (24-32 ${ }^{\circ} \mathrm{C}$ ), low rainfall and the absence of cultural practices such as deleafing and desuckering during the dry season increase aphid populations. BBTV is also likely to migrate towards higher altitudes and sub-tropics with rising temperatures (Taylor et al. 2016; Thornton and Cramer 2012) (Table 2). Increased nematode populations and greater root damage in banana by the root-burrowing nematode (Radopholus similis) are anticipated with rising temperature (Masters and Norgrove 2010; Jeger et al. 2017). A study by Neba et al. (2014) on the impacts of climate change on banana production in Cameroon found a positive correlation between temperature and nematode populations, which damage the roots, facilitate toppling, reduce the bunch size and yield.

Banana and plantain breeding programs are very complex because of the improvements in diploid, triploid and polyploidy level; therefore, the clonal distribution of elite varieties should be prioritized. Resistant genotypes such as Giant Kalapua, a drought-tolerant variety in Vanuatu and the Fe'i bananas resistant to BLSD have been successfully identified (Taylor et al. 2016). Chromosome aberrations (inversions and translocations) examined by Shepherd (1999) between various accessions of $M$. acuminata can be correlated with reproductive isolation of island ecosytems. Allelic diversity of genotypes cultivated in the world is remarkably narrow and the risk of genetic erosion due to the deployment of new diseases is also rising due to climate change. Diploid varieties can accumulate diverse 
sources of resistance to diseases, pests and also regulatory genes for shelf life. Therefore, marker-assisted selection may be an invaluable tool for the improvement of diploids in the Pacific. Exploitation of combining abilities to develop superior triploid hybrids through somatic hybridization can also offer opportunities to develop novel gene combinations for exploring allelic dosages. Induced mutations and TILLING strategies also have considerable potential to enhance phenotypic variability for withstanding extreme climatic conditions in the region. Hence, the screening of traditional cultivars of banana and plantains should be an integral aspect of any crop improvement program in the Pacific region to assemble "climate ready collection". Germplasm collections exist in NARI, PNG (235), Ministry of Agriculture and Fisheries, Samoa (21), Kastom Gaden Association, Solomon Islands (138) and Institut Agronomique néo-Calédonien, New Caledonia (80). The University of South Pacific, Alafua Campus, Samoa and SPC are carrying out breeding activities or crop improvement programs through networking with Australian universities or Institutions.

\subsubsection{Papaya}

The optimum range of temperature for papaya (Carica papaya) production is $21-33{ }^{\circ} \mathrm{C}$, and temperatures greater than $35^{\circ} \mathrm{C}$ induce female sterility in papaya plants, a condition in which normally hermaphrodite flowers turn functionally male, with poorly developed, non-functional female parts, causing flower drop and creating gaps in fruit sets called skips (Teves 2016; Chan 2009). This conversion of hermaphrodites to pistillate flowers also takes place under drought stress (daSilva et al. 2007; Chan 2009) causing reduced fruiting (Teves 2016; Paull and Duarte 2011). High rainfall and humidity on the other hand may predispose the plants to fungal diseases such as phytophthora and anthracnose particularly in areas with a high water table, water logged soil and persistent high rainfall (Nishina et al. 2000; Paull and Duarte 2011). Flooding or incessant rainfall may cause chlorosis of lower leaves and loss of leaf turgidity (Chan 2009), and in severe cases, leaf abscission and root rot followed by death of the plant may occur (Paull and Duarte 2011). In Moloa'a, Hawaii, post hurricanes Iwa in 1982 and Iniki in 1992, wet conditions promoted the development of the fungal pathogen, Phythophthora infestans which severely destroyed the papaya crop (Teves 2016). Elevated $\mathrm{CO}_{2}$ concentration increases fecundity of Colletotrichum gloeosporioides which causes anthracnose in Papaya (Chakraborty and Datta 2003). In Vanuatu, the Papaya mealy bug (Paracoccus marginatus) has been identified as a high risk exotic pest (Freeman et al. 2012). Fullerton et al. (2011) reported the first incidence of Bacterial Crown Rot of Papaya (Erwinia spp.) in Tonga, which caused massive devastation to the papaya industry. The disease occurs in wet tropical regions, (Tonga and Fiji in the Pacific) and spreads locally through wind driven rain (Jackson 2017). However, some varieties are more resilient to crown rot of papaya than others, necessitating the need to identify resistant cultivars for strengthening adaptation strategies through crop improvement programmes in the Pacific. Papaya is sensitive to wind damage which can reduce plant growth, impair leaf development, fruit set and fruit quality, trigger flower and young fruit abscission, and significantly lower productivity, even uprooting trees in strong wind conditions (Nishina 2000; Paull and Duarte 2011). Among the diseases affecting papaya, the most widespread and destructive is transmitted by aphids, the PRV which reduces fruit production and lowers sugar concentration (Gonsalves 1998), and is projected to increase with increasing temperatures (Ghini et al. 2011). The influence of weather conditions on population dynamics of aphid vectors and their role in field spread of PRV was studied by 
Kalleshwaraswamy et al. (2007). Their work indicated that temperature, population density and crop ageing are positively correlated whereas windspeed and rainfall are negatively correlated with aphid formation and migration. Incidences of PRV are therefore anticipated to rise with rising temperature due to increasing proliferation of aphid vectors (Kalleshwaraswamy et al. 2007), and decline with heavy rainfall due to increased vector mortality (Pushpa et al. 2019). Under climate change, research priorities should focus on extending fruit storage, shelf life and disease resistance in papaya. Upscale traits such as enhancement of phytochemical and nutritional components can be enhanced by marker aided selection through nutrigenomics approach by networking projects. Papaya has moderate salt tolerance but in coastal areas wind-borne salt sprays desiccate leaves, causing death of plants (Nishina 2000). The effect of irrigation with saline water on papaya indicates that high soil salinity reduces the petiole and leaf phytomass along with significant reduction in leaf area (Lima Neto et al. 2016; Sousa et al. 2019; Parés and Basso 2013) (Table 2). With countries such as Fiji depending on just one variety of Papaya, the gynodioecious variety, Sunrise Solo, and hence a high vulnerability to climate change, there is immense scope for crop improvement and the development of heat and flood-tolerant varieties which can sustain future productivity.

\subsubsection{Mango}

Mango (Mangifera indica) trees are moderately wind tolerant, which depends to a considerable degree on tree size, with larger, unpruned trees more susceptible to branch breakage and uprooting during intense cyclones as compared to pruned ones (Bally 2006; Crane et al. 2009). Protection from prevailing winds by creating windbreaks on mango orchards increases productivity due to reduced physical damage to leaves and fruits, and improved fruit sets (Janick and Paull 2008). To avoid wind breakage during cyclones, reduced tree size and height (dwarfing) are desirable traits which could be induced in scions by rootstocks. High phenolic percentage, phloem to xylem ratio, source sink relationship and less number of new shoots developing into flushes are characteristics associated with dwarfing (Iyer and Kurian 1992). Lack of apical dominance in some cultivars could be used for further crop improvement to develop suitable dwarf varieties with precocity (Iyer and Dinesh 1997). During flowering and fruiting, high humidity and rainfall reduces the yield and productivity of mango trees (Bally 2006). In Fiji, shifting precipitation patterns, particularly high rainfall has been held responsible for recent observations of no fruiting in mango (McLean and Heckler 2017). Heavy rainfall increases infection by the mango anthracnose, Colletotrichum gloeosporioides, particularly in new leaves when emergence coincides with wet weather. Conidia formation takes place in moist conditions and dissemination occurs passively through rain splash (Bally 2006; Nelson 2008). In the PICs mango anthracnose has widespread occurrence and has been reported from Fiji, PNG, Solomon Islands, Tonga, Vanuatu, Palau, Cook Islands, FSM, Guam, Marshall Islands and New Caledonia (Tsatsia and Jackson, 2017). Biotechnological tools could be employed for the identification of abiotic stress tolerance genes and somatic embryogenesis of tolerant rootstocks for anthracnose resistance in the region. Some varieties can tolerate flooding up to 50 days due to the development of hypertrophic stem lenticels above the water level to facilitate internal diffusion of oxygen to the flooded roots or elimination of toxic metabolites formed during anaerobic root respiration (Bally 2006; Larson 1991; Janick and Paull 2008) (Table 2). Mango can withstand seasonal drought up to 8 months (Bally, 2006) due to an extensive deep taproot system, desiccation-tolerant surface feeder roots, rapid stomatal closure, thick cuticle 
and resin canals to reduce wilting (Bally 2006; Janick and Paull 2008; Schaffer et al. 2009). The root stock of Mangifera inocarpoides has tolerance to water logging conditions (Iyer 1991) and could be conserved through in-situ and participatory plant breeding approaches. Drought may have both positive and negative effect on fruit quality in non-irrigated mango orchards, with water deficit increasing dry matter and sugar content but reducing fruit size (Normand et al. 2015). Water availability is critical during the initial stages of fruit development, where drought may trigger fruit drop and decrease fruit phytomass due to reduction in cell size and number (Wei et al. 2017; Janick and Paull, 2008). In mango the optimum temperature for vegetative growth ranges between 19.5 and $28.8^{\circ} \mathrm{C}$, and reproductive growth occurs when temperatures are higher than $12-15^{\circ} \mathrm{C}$ (Dambreville et al. 2013; Geetha et al. 2016). Temperature affects both vegetative and reproductive organs in mango; exhibiting an inverse relationship with inflorescence size (Dambreville et al. 2013), and positively correlated with leaf size, number of growth flushes and leaves per flush (Whiley 1989). Extremely high temperature desiccates pollen, accelerates the rate of panicle and flower development, shortens flowering duration, lifespan and days for effective pollination, thereby adversely affecting productivity (Shu 1999; Nath et al. 2018). High soil surface temperature increases incidences of spongy tissue in the Alphonso variety cultivated in Konkan region, India, and can be controlled by adopting management practices such as sod culture which moderates soil temperature (Nath et al. 2018; Katrodia and Sheth 1989). Olesen (2011) however, reported positive influence of warming on mango production in Northern New South Wales, Australia, where winter temperature rise of $1.5{ }^{\circ} \mathrm{C}$ between 1963 and 2009 decreased the time to fruit maturity by 12-16 days (7-8\%). Mango trees are salt intolerant and saline soils may induce necrosis, leaf abscission and defoliation, stem dieback, reduced growth and may also impair their defensive mechanism against pathogens (Bally 2006; Janick and Paull 2008; Vieccelli 2017). Deivasigamani et al. (2019) reported adverse impacts on morphological parameters of mango seedlings subjected to salt stress including reduced girth, height, number of leaves, leaf area and specific leaf weight. Rootstocks with high tolerance to saline soils such as the Israeli cultivar '13-1' (Gazit and Kadman 1980), and Gomera from Canary Islands (Zuazo et al. 2004) can be introduced for improving tolerance in commercial varieties of the Pacific. It is also important to initiate studies exploring the biochemical, physiological and molecular factors governing nutrient uptake under saline conditions (Zuazo et al. 2004).

\subsubsection{Betelnut}

Impacts of climate change on betelnut (Areca catechu) cultivation in the PICs have been insufficiently explored, although the palm is sensitive to environmental extremes. The palm has low tolerance to cyclones, drought, waterlogging and high temperature (Staples and Bevacqua 2006; Taylor et al. 2016). Under conditions of water deficiency, growth and development is adversely affected resulting in flower abortions, small nut size and reduced yield, hence irrigation is recommended during dry summer months (Staples and Bevacqua 2006). In Palau, during typhoon Bopha in 2012 betel nut was severely affected by saltwater intrusion (SPC 2013). Beletelnut trees in Maledok Island, PNG, are wilting and dying due to king tides and sea level rise which are inundating coastal areas (Caritas 2018) (Table 2). Higher incidence of phytophthora diseases (fruit rot), reduced pollination and nut development in betelnut were observed by Sujatha et al. (2018) in Vittal, Karnataka, India, due to heavy rainfall. A study on the viability of betelnut under drought stress in Hainan Province, China revealed reduced growth and aboveground and belowground biomass of palms, 
the impacts being more pronounced in seedlings ( $\mathrm{Li}$ et al. 2018). There have been very limited crop improvement programmes in betelnut. None of the available cultivars has shown resistance to yellow leaf disease and therefore developing disease-resistant genotypes should be prioritized. Moreover, the development of dwarf high yielding varieties can enhance betelnut productivity in the region (Brotonegro et al. 2000; Staples and Bevacqua 2006).

\subsection{Underutilized crops/orphan crops}

Many neglected and underutilized species are acclimatized to low-input agriculture, resistant to biotic and abiotic stress and can grow in marginal and harsh environmental conditions (Chivenge et al. 2015). Such orphan crops can make valuable contributions to enhancing the resilience of marginal farming systems to climate change, food and nutrition security, and crop improvement (Mabhaudhi et al. 2017). Adaptation of communities to climate change can be enhanced through the promotion of underutilized crop species as nutrient rich alternative food crops, recognition of their role in the conservation of agrobiodiversity and traditional faming systems, and generation of socio-economic and livelihood benefits (Mabhaudhi et al. 2019). In the PICs some traditional underutilized crops include Pandanus, amaranthus, aibika and duruka.

\subsubsection{Pandanus}

Pandanus is well adapted to drought, water logging, saltwater intrusion and warmer temperature in atoll environments. The tree has impeccable soil tolerance and is well adapted to grow in shallow, saline, sodic, nutrient poor soil, as well as peat swamps. In atoll ecosystems it is considered more drought tolerant than coconuts and breadfruits; can tolerate drought up to a period of 6 months and continues to bear fruits during dry spells although smaller in size and lower in number. However, a study on physiological responses and adaptations to water deficits in Pandanus by Marler et al. (1996), revealed reduced carboxylation efficiency, photochemical efficiency and relative leaf water content under drought stress. Conversely, it has broad adaptability to soil moisture conditions and can grow in free, impeded or seasonally waterlogged soil. Pandanus is also resistant to strong winds, salt laden winds and moderate to severe tropical cyclones (Category 1-3), but may be uprooted during intense tropical cyclones (Lim 2012; Thomson et al. 2006; Taylor et al. 2016). However, despite an incredible ability to grow under constrained environments, the tree is not immune to climate change. During more severe cyclones, beach Pandanus may be deracinated as an effect of beach sand being eroded away during storm surge (Calvert 2011). In Kiribati, prolonged soil salinity, saltwater intrusion and coastal erosion have been reported to reduce the productivity of Pandanus (Wairiu et al. 2012) and cause stunted tree growth (Freeman et al. 2012) (Table 2). In Narikoso Village, Kadavu, sea level rise and saltwater intrusion is damaging the roots of Pandanus trees and reducing the yield of leaves in the only village plantation. This has jeopardized the livelihood of the local population, which is highly dependent on the plantation for mat weaving (Chandra 2018). In Tonga, Cyclone Ian, 2014, caused extensive damage to Pandanus trees and adversely affected the livelihood of women since leaves become suitable for mat making only after a period of two years (Aipira et al. 2017). The Pandanus scale insect Thysanococcus pandani which invades Pandanus tectorius is a serious cause of concern in the Pacific Islands (Neville 2014), and climate change may trigger rapid multiplication and dissemination of this pest. 
Crop improvement efforts need to concentrate on the screening of landraces and traditional cultivars to identify valuable genotypes which can be used for the identification and propagation of resistant varieties.

\subsubsection{Amaranthus}

Amaranths have the ability to grow in diverse soil and agro-climatic conditions, including marginal lands and soils of low fertility, in environments ranging from the tropics to arid and semi-arid regions, and from the sea level to high mountain ranges (NRC 1984). They are heat stress and drought tolerant (Ohshiro et al. 2016; Svirskis 2003; Rastogi and Shukla 2013); following a drought amaranths tend to increase their root-shoot ratios, which increases their ability to withstand the dry spell (Hoidal et al. 2019), though drought tolerance is superior in grain amaranths compared to the leafy ones (NRC 1984; Das 2016). Amaranths are also salt-tolerant plants; enhanced protein, fibre, energy, ash and carbohydrate content in leafy amaranths under salt stress was reported by Sarker et al. (2018). Therefore, this crop may be recommended to farmers as an adaptation strategy in areas facing problems of soil salinity without adverse impacts on the nutritive value. Another favourable aspect is tolerance to most pests and diseases, however, Wang and Ebert (2012), reported increased infestation by the fungal disease white rust caused by Albugo bliti in leafy amaranth under hot and humid conditions during the summer season in Taiwan. Strong winds may cause seed shattering, lodging and stem breakage (Paredes-Lopez 2017; Hoidal et al. 2019). Breeding programmes focussing on development of white rust and non-shattering, lodging resistant varieties should be initiated in the Pacific region, along with programmes on increasing awareness regarding the nutritional value of the crop.

\subsubsection{Aibika/bele}

Aibika (Abelmoschus manihot) is affected by diseases such as collar, stem and tip rot (Phytophthora nicotianae) which increases in high rainfall and poor soil drainage conditions (Preston 1998). Rauka and Shigaki (2015), reported in Nawae and Markham districts, Morobe province, PNG, high incidences of wilting and death of aibika plants due to collar rot. High rainfall and flooding increased infestation by $P$. nicotiane, which formed a disease complex with Fusarium spp, the causal agent of Fusarium wilt. Under high rainfall, wilting and death of plants may also occur due to infestation by aibika shoot borer caterpillar (Earias vitella) (Solomon Islands Government, 2014). Prolonged dry spells on the other hand reduce leaf area and crop yield, as well as increase damage by pests such as spider mites (Tetranychus sp.), aibika leaf roller (Sylepta derogata) and jassid (Amrasca devastans) (Preston 1998; Taylor et al. 2016) (Table 2). Leaves of aibika turn leathery and fibrous in water deficit sites, resulting in reduced palatability (FAO 2009). Saltwater intrusion is also detrimental for aibika. Plants growing in saline soil exhibit slower growth and development, and a reduction in the number of leaves and crop yield (Sen 2017). Brunt and Spence (2000) reported the incidence of Hibiscus Chlorotic Ringspot Virus (HCRSV) in aibika in some countries of the South Pacific such as Fiji, PNG, Solomon Islands and Vanuatu, previously reported to only infest the ornamental shrub H. rosa-sinensis. It has been observed that varieties with pinnate and lanceolate leaves are less susceptible to incidences of pest and disease attack compared to those with broad leaves (Preston 1998). Therefore, varietal screening of aibika for pest and disease resistance should be prioritized in Pacific plant breeding programs. So far crop improvement programmes focussing on 
aibika have been very limited. Although new variants resulting from natural cross pollination have been observed in farmers' fields but limited intervarietal hybridization programs have been initiated for climate change adaptation in the PICs. A total of 47 varieties have been identified and collected from four countries as a core regional sample collection and preserved through in vitro conservation techniques at CePaCT in Fiji (Tuia et al. 2015). Recent genetic variability studies on PNG varieties suggest that environmental features have a more dominant influence on micronutrient concentration than the genotype. Therefore, breeding programs focussing on enhancing the nutritive value of aibika should consider the relationship between micronutrient content and environment (Lydia RubiangYalambing et al. 2016).

\subsubsection{Duruka}

In Fiji two types of duruka (Saccharum edule) are recognized based on the colour of the outer stem: duruka damu or the red duruka which has a single variety and duruka vulavula or the white duruka which has six varieties (Waqaniu-Roger 1986). Duruka ni Maleya or duruka vua vakarua (Malayan duruka) is the purple variety, a relatively recent introduction in Fiji which matures twice a year. Duruka is also being exported by the country to Australia, New Zealand and USA as the "Fijian Asparagus" (Lim 2014). It can grow in a wide range of soil and agro-climatic conditions, and can withstand short periods of seasonal inundation (Lim 2014). Duruka has ceased flowering in some areas of Fiji due to shifting precipitation patterns (high rainfall and floods) which has considerably affected crop yield and the livelihood of farming communities (McLean and Heckler, 2017). In Nabulini, Naibita and Manu villages of Fiji, TC Winston caused severe damage to agricultural crops including duruka (ILO 2016). Whilst 14 accessions have been reported from Fiji (FAO 2008b), PNG has 28 accessions of S. edule (Kambuou 1995). There is a strong need to collate genetic resources of $S$. edule in the Pacific Islands, broaden the genetic base of the crop through participatory breeding approaches and assess the impacts of climate change on the crop.

\subsection{Other crops}

\subsubsection{Sugarcane}

Sugarcane production decreased in Fiji from 4,016,000 tons in 1990 to 1,631,000 tons in 2017 (Fig. 3). This decline in production is due to several factors: expiring land leases and decrease in the area under cultivation, removal of the European Union preferential sugar prices, low crop productivity, high cost of production, labour scarcity (Singh 2020), and vulnerability to natural disasters (Government of Fiji 2009). Rosegrant et al., 2015 estimated losses of US\$375 million in Fiji's sugarcane production over the period 2008-2050, equivalent to a loss of US\$8 million per year, due to climate change.

Sugarcane is a crop which is highly vulnerable to climate change (Table 2). Cyclones are responsible for extensive damage to sugarcane plantations. The extent of wind damage during cyclones varies with the age of the crop; canes $<3$ months old suffer broken tops and leaf shredding, canes 3-5 months old experience stalk breakage, and canes older than 5 months may be subjected to lodging (Bedasse 2017). The economic cost of cyclone damage to sugarcane farmers in Fiji was 20 million US\$ in 1983 due to TC Oscar, and 21.7 million US\$ due to TCs Eric and Nigel in 1985 (Rosegrant et al. 2015). Both drought 


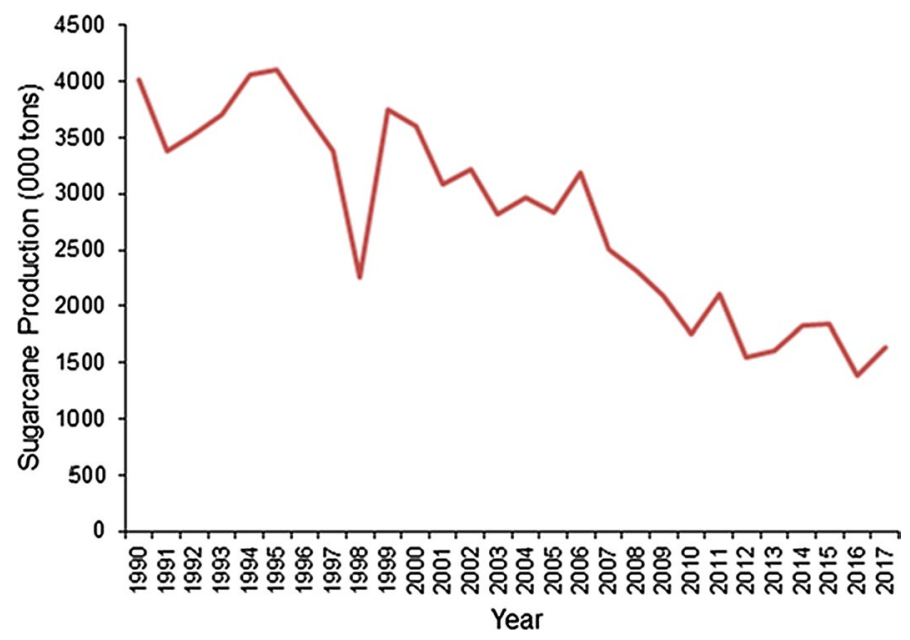

Fig. 3 Annual production of sugarcane in Fiji over 1990-2017 Source Fiji Bureau of Statistics (2019)

and waterlogging are detrimental for cane growth, and can reduce yield by up to $60 \%$ and $18-64 \%$ respectively, depending on the cultivars, duration of stress and plant growth stage (Zhao and Li 2015; Hussain et al. 2018). Misra et al. (2020) compared morphological losses in sugarcane subjected to drought versus waterlogging and found higher losses under water deficits. Drought reduces cane length, stalk diameter, leaf area, biomass accumulation, cane weight and sugar yield (Dinh et al. 2018; Misra et al. 2020). In Fiji, sugar production stood at 5,16,529 tons in 1994 due to favourable weather conditions which reduced by 47,50 , and $43 \%$ respectively in the years 1997, 1998, and 2003, compared to the production in 1994 due to drought (Zhao and Li 2015). In response to flooding, changes in root anatomy facilitate survival under anaerobic conditions, principally formation of aerial roots, adventitious roots and aerenchyma tissues. Reduction in cane length and diameter, tiller number, leaf area, dry matter production, crop yield along with nutrient imbalance which causes yellowing of leaves, has been reported under waterlogging in sugarcane (Gomathi et al. 2015). Soil salinity is another factor which impairs sugarcane juice quality (Lingle and Wiegand 1997). Salt stress reduces the rate of photosynthesis and biomass assimilation, cane length and crop yield (Vasantha et al. 2010). During the 2009 flash floods in Fiji, low-lying areas such as mangrove reclaimed land used for cane cultivation was inundated by saltwater and could not be used for cultivation for as long as 2-3 years. Reduced cane productivity due to water logging, saltwater intrusion and/or siltation was reported from other flood affected areas (Lal et al. 2009). Rising sea level and king tides have emerged as a major concern for farming communities engaged in sugarcane production along coastal areas. This in part has aided in the decline of sugarcane production in Fiji as the industry struggles to cope with arable land becoming inundated with salt water. Warmer temperatures may also have adverse impact on cane production. Temperatures above $32{ }^{\circ} \mathrm{C}$ reduce sucrose content and the length of internodes, and increase stalk fibre which degrades the cane quality (Bonnet et al. 2006). In Fiji, a major limitation of sugar production is the erratic sucrose content which may be further reduced with increasing temperature. High temperatures also promote the development of the planthopper Perkinsiella saccharicida, vector of the Fiji Disease Virus (FDV). FDV causes Fiji leaf gall also 
called Fiji disease of sugarcane first reported in Fiji in 1890, which causes significant yield losses in the Asia Pacific region (Vercambre 2010).

As per the Sugarcane Research Institute of Fiji (SRIF) there was a period of around 20 years in Fiji, when no new varieties were introduced, resulting in a low genetic base of the cane germplasm. The development of new varieties and hybrids introduces new genes into the existing gene pool thereby assisting in germplasm diversification through gene introgression by Marker Aided Selection and hybridization programmes. It is therefore recommended that research on breeding drought, flood and salinity resistant cane varieties is undertaken to enhance adaptability to climate change.

\subsubsection{Rice}

Rice (Oryza sativa) production in Fiji has been steadily declining from 32,147 tonnes in 1990 to 9,081 tonnes in 2017 (Fiji Bureau of Statistics 2019). Before deregulation traditional rice varieties which exhibited tolerance to drought and water logging were cultivated by farmers in $80 \%$ of the rainfed wetland areas (Bong et al. 2017). Today the area under rice has decreased dramatically and fields previously used for rice cultivation have turned barren particularly in low-lying areas due to high levels of soil salinity. Rosegrant et al. (2015) projected a decrease in rainfed rice yield in the country due to climate change in the year 2050 as compared to 2000 ranging between 4 and 11\%, but if optimal cultivars and planting months are adopted as adaptation measures then the change in yield may range from a decline of $5.3 \%$ to an increase of $0.2 \%$.

Rice production depends on climatic factors. Cyclones may cause stripping and injury to the rice plant or lodging, resulting in significant yield reductions (Blanc and Strobyl 2016). Rice is highly sensitive to water deficits, particularly during anthesis and fertilization phases when harvest index can be lowered by as much as 60\% (Barnabas et al. 2008). Adverse impacts on rice yield and productivity due to water stress are a result of reduction in plant height and biomass assimilation, leaf area index, tiller number, panicle number and length, filled grains per panicle, delay in flowering and spikelet fertility (Dar et al. 2020; Saikumar et al. 2016). Reduction in rice yields are also attributed to reduced rate of seed setting, grain size and weight (Dar et al. 2020). Although extreme submergence or flooding is deleterious to rice cultivation, the crop has tolerance to anaerobic conditions through the development of aerenchyma cells which facilitate transport of oxygen from unsubmerged shoots to submerged roots, and rapid shoot elongation to rise above the flooded soil (Nishiuchi et al. 2012). However, if floodwaters are very deep or flooding period is long, then once the water recedes, most plants experience lodging and die due to exhaustion of energy reserves (Oladosu et al. 2020). Rice is however, highly sensitive to soil salinity. Salt stress is responsible for poor rice grain yield due to reduced rate of photosynthesis, restricted leaf growth, accelerated leaf senescence and panicle sterility (Hussain et al. 2017; Razzaq et al. 2019). Nutritional deficiencies are exacerbated under high soil salinity due to decreased uptake of nutrients, and competition of $\mathrm{Na}^{+}$and $\mathrm{Cl}^{-}$ions with macronutrients: $\mathrm{N}, \mathrm{P}, \mathrm{K}^{+}$, $\mathrm{Ca}^{2+}$ and micronutrients: $\mathrm{Fe}, \mathrm{Mn}$ and $\mathrm{Zn}$ (Hussain et al. 2017). In Nataleira village of Fiji, a major rice growing area, decline in rice yield due to rising sea levels, storm surges and saltwater intrusion has resulted in the abandonment of rice farming (Iese et al. 2020). Optimum temperature for rice cultivation ranges between 27 and $32{ }^{\circ} \mathrm{C}$, beyond which significant yield reduction takes place due to spikelet sterility in the grain filling period (Korres et al. 2017; Thuy and Saitoh 2017; Yang et al. 2017). Spikelet sterility is attributed to temperature driven loss of pollen viability, poor anther dehiscence, and reduced adhesion and 
germination of pollen grains on stigma (Endo et al. 2009; Yang et al. 2017). With rising temperatures particularly in the critical grain filling stage, degradation in milling quality and increased kernel susceptibility to breakage has been reported by several authors (Lanning et al. 2011; Lyman et al. 2013; Morita et al. 2016). This deterioration in rice quality is a result of the inhibition of starch accumulation and consequent rise in grain chalkiness. Other effects on rice eating quality and processing characteristics include, decreased amylose content and high gelatinization temperature and viscosity (Korres et al. 2017; Patindol et al. 2014). It is important that new salt tolerant, short duration and high yielding rice varieties are introduced to enhance current productivity levels under changing climatic conditions. A recent study by Palanivel et al. (2016) focussed on the physicochemical properties of different rice varieties in the country in order to identify varieties for crop improvement trials. Further research is necessary to increase resistance to climatic extremes.

\subsubsection{Kava}

Kava (Piper methysticum) is highly susceptible to cyclone damage particularly after a year of planting, when strong winds may break tops, disturb roots and kill the plants. Kava cultivation is therefore recommended in gardens or plantations surrounded by forests or in agroforestry systems where trees can act as a windbreak and protect the crop (PHAMA 2017). In Samoa, Cyclone Ofa which struck in 1990 damaged $25-75 \%$ of the kava crop (McGregor and McGregor 1999), and in Fiji TC Winston caused extensive damage to kava plantations resulting in reduced supply and high prices in 2016 (PHAMA 2017). Kava grows best in areas of high rainfall $>2,200 \mathrm{~mm}$, and is highly vulnerable to water stress which may cause wilting and necrosis (Davis and Brown 1999). Drought tolerance however depends on the age of the crop; young plants are drought intolerant but those more than a year old can withstand dry conditions up to one month (Nelson 2011). The 2015-2016 El Niño drought in Tonga caused severe damage to the crop resulting in a 500\% rise in kava prices (WTO 2019). Dry weather also increases the population of aphids which serve as a vector of Cucumber Mosaic Virus (CMV). CMV causes kava dieback, the most devastating of all kava diseases in the South Pacific particularly affecting countries such as Fiji, Vanuatu, Samoa and Tonga (Davis 1999). Despite a preference for wet areas, the plant cannot withstand waterlogging which may cause wilting, root rot and impair root growth and development, and therefore hill slopes are ideal for cultivation (PHAMA 2017). Kava is salt intolerant and should be planted in areas protected from salt sprays which can cause extensive destruction to the crop. High soil salinity may result in root rot, wilting, desiccation of leaves and even death of the plant (Davis and Brown 1999; Nelson 2011).

\section{Prioritizing crop improvement for enhancing resilience to climate change}

Germplasm collections of traditional crop species in the Pacific were morphologically characterized during the late 1980s (Guarino and Jackson 1986). Traditional crops such as taro, banana and sweet potato, most of which are vegetatively propagated in the region include a large number of landraces but have a very narrow genetic base, and therefore are vulnerable (Chipungu et al. 2017; Roullier et al. 2011) to biotic and abiotic stresses aggravated by climatic extremes. Within the PICs, as in the rest of the world, food crops need major genetic improvement for maintaining and enhancing crop production in the 
face of climate change. This is critical considering increasing risk of invasion by pests and pathogens in the region due to increased accessibility and improved transport systems, and rise in temperatures which facilitates an expansion in the range of their distribution. The absence of quality seed supply systems in small Pacific island nations escalates the pest and disease incidences through informal sharing of propagating materials among the communities which is a cultural practice in the region. Devastating diseases such as TLB which has affected most of the Pacific Islands may spread to neighbouring islands which are yet disease free such as Fiji, Tonga, Cook Islands, Niue and Vanuatu. It has been demonstrated that while crop management measures such as chemical and cultural control are ineffective, breeding strategies are among the most promising approach for addressing the issue (Singh et al. 2012).

Introducing crop varieties and their subsequent cloning from different parts of the world may not be a sustainable solution for managing responses of food production systems to climate change in the Pacific. Multidisciplinary approaches in plant breeding involving a combination of high throughput phenotyping, genomics, proteomics and metabolomics, and multi-environment trails of genotypes across diverse environments, are also gaining increasing popularity in recent times. However, in the Pacific region, insular constraints of island ecosystems along with the high financial costs involved are major limitations for any centralized crop improvement programs. A more viable approach would revolve around identification, conservation, documentation and dissemination of information on unique landraces at community, national and regional level to enhance their use in crop production and plant breeding programmes. The establishment of community seed banks for conservation and exchange of planting material, and improving existing varieties are also important crop improvement strategies for enhancing the resilience of the Pacific Islands agriculture sector to climate change.

\subsection{Screening traditional cultivars and landraces}

Most landraces exhibit resistance to biotic and abiotic stress, with intermediate but relatively stable yields, characteristics which are highly desirable in areas vulnerable to climatic changes. In Pohnpei 177 landraces of yam (Raynor et al. 1992), in Fiji 72 taro landraces (Taylor et al. 2010), and in Vanuatu 87 coconut landraces have been reported (Osborne 2005). Tisdell et al. (2014), however, raised concerns over the declining genetic diversity of traditional food crops in the Pacific most of which are highly resilient to climate change. Export driven market demands, crop substitution by new crops, promotion of few improved varieties popularized by local governments, urbanization, and changing food preferences are some of the factors driving this genetic erosion.

The exploration of genetic resources can facilitate efforts to enhance abiotic stress resilience including shifting precipitation patterns and temperature rise observed in the Pacific. However, a key issue in crop improvement is that most of the genetic resources till date have been utilized to introduce resilience to biotic rather than abiotic stress such as heat and drought stress (Reynolds et al. 2010). It is important to realize that yield losses from pests and pathogens are generally a result of aggregated biological synergy with weather conditions at critical crop developmental stages (Chakraborty and Newton 2011). Maintaining and utilizing a wide basket of genetic diversity in an era of rapid climate change will therefore be an essential insurance policy for the food and agriculture sectors. In insular environments, plant breeding approaches should therefore involve molecular characterization 
of existing germplasm in order to characterize and document allelic diversity of local food crops.

\subsection{Community seed banks}

Community seed banks enhance the resilience of farming communities to climate change by improving access to and availability of diverse, locally adapted crop varieties, through the collection, production, distribution and exchange of seeds. The introduction of new, resistant varieties from other parts of the same country or from different parts of the world for enriching the germplasm collection is another interesting aspect of most community seed banks. Another important function of community seed banks is the conservation and revival of local crop varieties, which often possess climate-resilient agronomic traits. They also enhance local knowledge and skills in the management of PGR through seed selection, treatment, storage and propagation (Vernooy et al. 2017). Other functions involved may be documenting traditional knowledge, empowering farmers, raising awareness and education, promoting ecological agriculture and participatory breeding activities (Vernooy et al. 2015).

\subsection{Conventional plant breeding}

Climate change and associated events such as elevated atmospheric $\mathrm{CO}_{2}$ levels and temperature will pose novel challenges for cultivated plant species. Selection and breeding has widened the scope of climatic adaptation for many crops far beyond their geographical origin and demonstrated the potential of crop production in constrained environments via recombination of their genetic makeup. Plant breeding is an accumulative and recurrent mechanism of selecting and crossing the most elite performing cultivars, and evaluating their progenies to identify those which are best adapted to a targeted environment. The climate-resilient variety can be evolved by (1) Identifying traits for adaptation to the new challenging climatic conditions, (2) Discovering genetic variation for the attributes or characters in the existing current or wild accessions of the species, (3) Introducing and selecting for these new genetic sources to develop cultivars through conventional, molecular, or engineering approaches; (4) Evaluating in large plots and releasing cultivars for adoption by growers.

Whitford et al. (2010) highlighted the application of biotechnology in plant breeding programs for reconstructing strategies for adaptation to climate change, giving specific examples of previous experiences or opportunities. Previous experiences suggest that most pests and pathogens develop specific genetic interactions with the host plant species. Climate also determines the distribution, development, and population dynamics of insect pests; increased pest abundance, colonization of new areas and range expansion are formidable challenges for agriculture (Lehmann et al. 2020). In extreme events such as hurricanes or cyclones, transcontinental invasion of fungal pathogens such as sugarcane rust and coffee leaf rust has been observed (Brown and Hovmøller 2002). On the other hand opportunities exist in the identification of resistant traits in nature. Most of the genetic traits related with tolerance to high temperature conditions are associated with growth and reproductive stages, and include variation in the time of day of flowering (Jagadish et al. 2008) and maintenance of pollen viability (Prasad et al. 2006). A considerable degree of prebreeding research is however mandatory to comprehend the genetic architecture of complex traits of resistance and identify how these networks are modified by climate change 
before they can be explored through plant breeding. Early involvement of plant breeders is also essential to dissect and develop selection strategies for complex traits (Eastburn et al. 2011).

\subsection{Participatory plant breeding (PPB)}

PPB is a collaborative breeding approach between different stakeholders including farmers, breeders, processors, traders, consumers and policy makers (Xu 2010). PPB gives farmers the freedom to decide which varieties are more suited to their needs and conditions in the target environment. It is a form of decentralized selection which overcomes the constraints of conventional breeding. Hence, although quite similar to conventional breeding programmes, key differences include on-farm rather than on-station selection, participatory decision making and independent implementation in diverse locations (Ceccarelli and Grando 2009). PPB contributes to farmers rights in multiple ways. It ensures effective adaptation of varieties to local agro-ecological conditions including extreme environments since testing fields are located within the community. Genetic material is chosen with the assistance of farmers and often traditional cultivars already grown by the locals are utilized. Farmers are therefore involved in decision making and their traditional knowledge is acknowledged and respected (Halewood et al. 2007). Another key aspect is that while commercial conventional breeding often caters to developing high yielding varieties for resource rich farmers, PPB addresses problems of poor farmers in developing countries (Ceccarelli 2012). PPB is particularly useful in high stress environments with poor agricultural yields, therefore it can be applied under circumstances where adaptation to adverse conditions is required (Ceccarelli 2012).

Enhancing the adaptation of agricultural crops and improving the resilience of farming communities to climate change can be achieved by investing in PPB approaches. Active involvement of farmers in crop improvement programs through participatory breeding approaches also facilitates exposure of farmers to new genotypes, which can play a key role in enhancing acceptance rates of climate-resilient new cultivars. Development of varieties suited to diverse extreme agro-ecological environments, allows PPB to maintain more genetically diverse varieties (Halewood et al. 2007). Adaptation to climate change can only be achieved by segregating progenies of parents from diverse and genetically distant origin crops. Core breeding materials can be intercrossed through natural or controlled crossing and superior progenies once segregated can be shared within the region. These segregates can also be utilized in PPB to recognize farmers' needs and preferences, and align future breeding strategies accordingly. PPB is therefore highly suitable for adoption in the Pacific where most of the farmers are smallholders, agricultural production is threatened by climate change and agrobiodiversity conservation is a major challenge. Therefore, it is envisaged that PPB approaches would generate far greater benefits than conventional breeding in the Pacific.

For farmers in the Pacific Island countries, sustained access to germplasm banks and international breeding programs for major traditional Pacific crops is notably influential to meet the hidden challenges of climate change in the region. Once a new trait target related to climatic change is identified, together with phenotypic screening for that trait, a breeding program consistently screens its own germplasm, as well as germplasm from national and international collections, in order to locate genotypic lines with improved performance for the trait that is very much needed to address environmental stress (Chapman et al. 2003). 


\subsection{Innovative plant breeding approaches}

Among the best strategic plan for any breeder is the selection of the genetic ancestor to be used in evolving a new set of crosses. The phenotypic recurrent selection method is currently being used in vegetatively propagated crops to estimate their breeding values under climatic stress. Notably in crops such as cassava, Rapid Cycling Recurrent Selection is an innovative breeding technique for improving the nutritional content especially enriching the carotenoid percentage in roots (Ceballos et al. 2013). Mutation breeding is a valuable tool to generate genetic variability and has resulted in the official release of almost 3275 mutant varieties in more than 220 plant species worldwide (Spencer-Lopes 2018). Reverse genetic techniques such as TILLING and Eco-TILLING through their characteristic high throughput platform are invaluable for well-organized and prompt induction of mutation events in developing climate-smart crops (Tadele et al. 2010). The reduction of cyanogenic compounds can be achieved by transgene silencing of RNA interference in cassava (Jørgensen et al. 2005). Moreover, hastened breeding of crop plants having targeted gene mutation(s) without foreign DNA is achievable using CRISPR genome editing as a promising technique for the development of climate-resilient cultivars (Wang et al. 2016). Another option is Marker-assisted breeding on the basis of photosynthetic capability due to significant natural variation in the germplasm of major crops (Lawson et al. 2012). This can assist in developing cultivars with higher $\mathrm{CO}_{2}$ assimilation, Water Use Efficiency and chlorophyll content (Lawson et al. 2012; Faralli et al. 2019; Flexas 2016). Genomics-based approaches and Next-Generation Sequencing have steered in sequence-based breeding programmes that can accelerate cloning of the allelic loci governing abiotic stress tolerance. Such approaches offer constructive opportunities to tap into CWRs and hence widening of the gene pool (Edwards et al. 2012). The concept "envirotyping" as proposed by Xu (2016) is alternative "typing" system accompanying phenotyping and genotyping to explicate environmental effects on agricultural crops. Through its competent mechanisms such as integral and complete phenotyping, genotype-by-environment interactions, genes related to abiotic and biotic stress signals, envirotyping enables crop modelling and phenotype extrapolation as well. The gradually expanding arena of fast, competent, high throughput and cost-effective molecular biology tools for recognizing metabolic networks, and tracing regulatory gene cascades of desired traits are transforming the management of PGR and reorienting crop improvements towards climate-smart agriculture.

\section{Conclusion}

Climate change in the Pacific is evident and could possibly devastate the agro-ecosystems in the region. Crop failures due to extreme weather events, and outbreaks of pests and diseases are fast emerging as key problems in the agriculture sector. At present there are limited initiatives to build food self-sufficiency and enhance resilience of agro-ecosystems in the Pacific region. It is enigmatic that PGR for food and agriculture are insufficiently utilized in the quest for increased food production under a changing climate even though there is ample compelling evidence pointing to the contrary. The paradigm of interdisciplinary approaches in plant breeding, particularly utilization of advanced genomics, phenomics, bioinformatics and subsequent multi-environment trials is gaining recognition in crop 
improvement programs worldwide. Such tools facilitate enhanced accuracy in screening traditional cultivars, landraces, obsolete varieties and new genotypes for identification of valuable traits. In many crop species, there are recognized activities in the areas of breeding and biotechnology for better adaptation to drought, waterlogging, salinity, and breeding, pests and pathogens. However, it is important to recognize the insular constraints of island economies and high financial cost involved in the application and promotion of high throughput techniques of crop improvement. Perhaps, a more feasible strategy would be to document and conserve genetic resources including landraces and traditional cultivars, invest in community seed banks and improve existing varieties through conventional and participatory plant breeding approaches. Plant breeding programs involving gene pool expansion and introduction of climate-smart agronomic traits in susceptible crops should be prioritized for climate resilient and sustainable agricultural production.

Funding None.

\section{Compliance with ethical standards}

Conflict of interest The authors declare that they have no conflict of interest.

\section{References}

Aipira, C., Kidd, A., \& Morioka, K. (2017). Climate change adaptation in Pacific Countries Fostering resilience through gender equality. In W. Leal Filho (Ed.), Climate change adaptation in Pacific Countries Fostering resilience and improving the quality of life. Switzerland: Springer.

Akrofi, S., Akuoko, K. O., Bour, K. B., \& Nyarko, J. A. (2018). Farmers' knowledge and perception of the dry cassava root rot disease in Brong Ahafo region of Ghana. Ghana Journal of Agricultural Science, $52,33-42$.

Alexandra, S., Jamora, N., Smale, M., \& Ghanem, M. E. (2020). The tale of taro leaf blight: A global effort to safeguard the genetic diversity of taro in the Pacific. Food Security. https://doi.org/10.1007/s1257 1-020-01039-6.

Anonymous. (2010). Edible aroids conservation strategy. https://www.genebanks.org/wp-content/uploa ds/2017/01/Edible-Aroids-Strategy-2010.pdf

APAARI. (2011). Strengthening of plant genetic resources for food and agriculture: Conservation and utilization in the Pacific. Bangkok, Thailand: Asia-Pacific Association of Agricultural Research Institutions.

Arnau, G., Némorin, A., Maledon, E., \& Abraham, K. (2009). Revision of ploidy status of Dioscorea alata L. (Dioscoreaceae) by cytogenetic and microsatellite segregation analysis. Theoretical and Applied Genetics, 118(7), 1239-1249.

Arzanlou, M., Abein, E. C., Kema, G. H., Waalijk, C., Carlier, J., Vries, Id., et al. (2007). Molecular diagnostics for the Sigatoka disease complex of banana. Phytopathology, 97(9), 1112-1118.

Asian Development Bank (ADB). (2009). Building climate resilience in the agriculture sector in Asia and the Pacific. Philippines: Asian Development Bank.

Asian Development Bank (ADB). (2011). Food security and climate change in the Pacific: Rethinking the options. Philippines: Asian Development Bank.

Asraf, M., \& Harris, P. J. C. (2004). Potential biochemical indicators of salinity tolerance in plants. Plant Science, 166(1), 3-16.

Australian Bureau of Meteorology and CSIRO. (2014). Climate variability, extremes and change in the Western Tropical Pacific: new science and updated country reports. Pacific-Australia climate change science and adaptation planning program technical report. Melbourne, Australia: Australian Bureau of Meteorology and Commonwealth Scientific and Industrial Research Organisation. https://www. pacificclimatechangescience.org/wp-content/uploads/2014/07/PACCSAP_CountryReports2014_ WEB_140710.pdf. 
Bally, I. S. E. (2006). Mangifera indica (mango). In C. R. Elevitch (Ed.), Species profiles for Pacific Island agroforestry. Holualoa, Hawaii: Permanent Agriculture Resources (PAR).

Bally, I. S. E., Lu, P., \& Johnson, P. R. (2009). Mango breeding. In S. M. Jain \& P. M. Priyadarshan (Eds.), Breeding plantation tree crops: Tropical species. New York: Springer.

Barnabas, B., Jager, K., \& Feher, A. (2008). The effect of drought and heat stress on reproductive processes in cereals. Plant, Cell and Environment, 31, 11-38.

Barnett, J. (2001). Adapting to climate change in Pacific Island Countries: The problem of uncertainty. World Development, 29(6), 977-993.

Barnett, J., \& Adger, W. N. (2003). Climate dangers and atoll countries. Climatic Change, 61, 321-337.

Bebber, D. P. (2019). Climate change effects on black Sigatoka disease of banana. Philosophical Transactions B, 374, 20180269.

Bedasse, J. (2018). Assessment of the vulnerability of Jamaica's agricultural sector to the adverse consequences of severe weather events. Kingston, Jamaica: Inter-American Institute for Cooperation on Agriculture (IICA). http://repositorio.iica.int/bitstream/handle/11324/7229/BVE18040318i.pdf;jsess ionid=209B158A8FB5165955941CE0566E0006? sequence $=1$.

Bell, J. \& Taylor, M. (2015). Building climate-resilient food systems for Pacific Islands. Program Report: 2015-15. Penang, Malaysia: World Fish.

Bell, J., Taylor, M., Amos, M., \& Andrew, N. (2016). Climate change and Pacific Island food systems: the future of food, farming and fishing in the Pacific Islands under a changing climate. Frederiksberg, Denmark: CGIAR Research Program on Climate Change, Agriculture and Food Security. https://hdl. handle.net/10568/75610.

Bellinger, M. R., Paudel, R., Starnes, S., Kambic, L., Kantar, M. B., Wolfgruber, T., et al. (2020). Taro genome assembly and linkage map reveal QTLs for resistance to taro leaf blight. G3 Genes Genomes Genetics, 10(8), 2763-2775.

Blanc, E., \& Strobl, E. (2016). Assessing the impact of typhoons on rice production in the Philippines. Journal of Applied Meteorology and Climatology, 55, 993-1007.

Boansi, D. (2017). Effect of climatic and non-climatic factors on cassava yields in Togo: Agricultural policy implications. Climate, 5(2), 28. https://doi.org/10.3390/cli5020028.

Bong, B. B. (2017). Review of the development of the rice industry in Fiji. Apia, Samoa: Food and Agriculture Organization of the United Nations.

Bonnett, G. T., Hewitt, M. L., \& Glassop, D. (2006). Effects of high temperature on the growth and composition of sugarcane internodes. Australian Journal of Agricultural Research, 57(10), 1087-1095.

Bourdeix, R., Johnson, V., Baudouin, L., Tuia, V. S., Kete, T., Planes, S., et al. (2011). Polymotu: A new concept of island-based germplasm bank based on an old Polynesian practice. Ogasawara Research, 37, 33-51.

Bourdeix, R., Johnson, V., Saena Tuia, S. V., Kapé, J., \& Planes, S. (2013). Traditional conservation areas of coconut varieties and associated knowledge in Polynesian Islands (South Pacific Ocean). In S. Larrue (Ed.), Biodiversity and societies in the Pacific Islands (pp. 199-222). Aix-en-Provence, France: Presses Universitaires de Provence (PUP), Université Aix-Marseille.

Bourke, R. M., \& Allen, B. (2009). Part 3: Village food production systems. In R. M. Bourke \& T. Harwood (Eds.), Food and agriculture in Papua New Guinea (pp. 193-269). Canberra, Australia: ANUE Press.

Brotonegro, S., Wessel, M., \& Brink, M. (2000). Areca catechu. In H. A. M. van der Vossen \& M. Wessel (Eds.), Plant resources of South East Asia NO.16, Stimulants (pp. 51-55). Leiden, Netherlands: Backhuys Publishers.

Brown, J. K. M., \& Hovmøller, M. S. (2002). Aerial dispersal of pathogens on the global and continental scales and its impact on plant disease. Science, 297(5581), 537-541.

Brown, O. (2008). Migration and climate change. Geneva, Switzerland: International Organization for Migration.

Brunt, A. A., \& Spence, N. J. (2000). The natural occurrence of Hibiscus chlorotic ringspot virus (Carmovirus;Tombusviridae) in aibika or bele (Abelmoschus manihot) in some South Pacific Island countries. Plant Pathology, 49, 798-798.

Burns, A., Gleadow, R., Cliff, J., Zacarias, A., \& Cavagnaro, T. (2010). Cassava: The drought, war and famine crop in a changing World. Sustainability, 2(11), 3572-3607.

Burson, B. (2010). Climate change and migration South Pacific perspectives. Wellington: Institute of Policy Studies.

Calberto, G., Staver, C., \& Siles, P. (2015). An assessment of global banana production and suitability under climate change scenarios. In A. Elbehri (Ed.), Climate change and food systems: Global assessments and implications for food security and trade (pp. 265-291). Rome: Food and Agriculture Organization of the United Nations. 
Calvert, G. (2011). An assessment of tree susceptibility and resistance to cyclones-with particular reference to Severe Tropical Cyclone Yasi in Townsville on 2nd February 2011. Report prepared for Townsville City Council and Ergon Energy, Greening Australia, Norman Park, Queensland. https:// www.greeningaustralia.org.au/wp-content/uploads/2017/11/RESEARCH_Yasi_TreeReport_NewFo rmat.pdf.

Campell, J. R. (1951). Dealing with disaster: hurricane response in Fiji. Suva, Fiji: Government of Fiji. https ://scholarspace.manoa.hawaii.edu/bitstream/10125/21944/1/DealingWithDisaster1984\%5Bpdfa\%5D. PDF.

Caritas. (2018). Waters of life, oceans of mercy: Caritas State of the Environment for Oceania 2018 Report. Aotearoa, New Zealand: Caritas. https://reliefweb.int/report/world/waters-life-oceans-mercy-caritasstate-environment-oceania-2018-report.

Carmichael, A., Harding, R., Jackson, G., Kumar, S., Lal, S. N., Masamdu, R., et al. (2008). Taro Pest: An illustrated guide to pests and diseases of taro in the South Pacific. Canberra Australia: Australian Centre for International Agricultural Research (ACIAR).

Ceballos, H., Hershey, C., \& Becerra-López-Lavalle, L. A. (2012). New approaches to cassava breeding. Plant Breeding Reviews, 36, 427-504.

Ceballos, H., Morante, N., Sánchez, T., Ortiz, D., Aragón, I., Chávez, A. L., et al. (2013). Rapid cycling recurrent selection for increased carotenoids content in cassava roots. Crop Science, 53, 2342-2351.

Ceccarelli, S. (2012). Plant breeding with farmers: A technical manual. Aleppo, Syria: ICARDA.

Ceccarelli, S., \& Grando, S. (2009). Participatory plant breeding in cereals. In M. J. Carena (Ed.), Cereals (pp. 395-414). New York: Springer-Verlag.

Chakraborty, S., \& Datta, S. (2003). How will plant pathogens adapt to host plant resistance at elevated $\mathrm{CO}_{2}$ under a changing climate? New Phytologist, 159, 733-742.

Chakraborty, S., \& Newton, A. C. (2011). Climate change, plant diseases and food security: An overview. Plant Pathology, 60, 2-14.

Chan, Y. K. (2009). Breeding Papaya (Carica papaya L.). In S. M. Jain \& P. M. Priyadarshan (Eds.), Breeding plantation tree crops: tropical species. New York, USA: Springer. https://doi.org/10.1007/978-0387-71201-7_4.

Chandra, S. (2018). Villagers fret over future of Pandanus plantations. https://fijisun.com.fj/2018/08/22/villa gers-fret-over-future-of-pandanus-plantations/

Chapman, S., Cooper, M., Podlich, D., \& Hammer, G. (2003). Evaluating plant breeding strategies by simulating gene action and dryland environment effects. Agronomy Journal, 95, 99-113.

Chipungu, F., Changadeya, W., Ambali, A., Saka, J., Mahungu, N., \& Mkumbira, J. (2017). Genetic and morphological diversity among sweet potato (Ipomoea batatas (L) Lam.) accessions from different geographical areas in Malawi. African Journal of Biotechnology, 16(22), 1285-1296.

Chivenge, P., Mabhaudhi, T., Modi, A. T., \& Mafongoya, P. (2015). The potential role of neglected and underutilised crop species as future crops under water scarce conditions in sub-Saharan Africa. International Journal of Environmental Research and Public Health, 12(6), 5685-5711.

Christensen, J. H., Kumar, K. K., Aldrian, E., An, S. I., Cavalcanti, I. F. A., de Castro, M., Dong, W., Goswami, P., Hall, A., Kanyanga, J. K., Kitoh, A., Kossin, J., Lau, N. C., Renwick, J., Stephenson, D. B., Xie, S. P., \& Zhou, T. (2013) Climate Phenomena and their relevance for future regional climate change. T. F. Stocker, D. Qin, G. K. Plattner, M. Tignor, S. K. Allen, J. Boschung, A. Nauels, Y. Xia, V. Bex, \& P. M. Midgley (Eds.), Climate Change 2013: The Physical Science Basis. Contribution of Working Group I to the Fifth Assessment Report of the Intergovernmental Panel on Climate Change (pp.1217-1308). Cambridge, United Kingdom and New York: Cambridge University Press.

Church, J. A., Clark, P. U., Cazenave, A., Gregory, J. M., Jevrejeva, S., Levermann, A., Merrifield, M. A., Milne, G. A., Nerem, R. S., Nunn, P. D., Payne, A. J., Pfeffer, W. T., Stammer, D., \& Unnikrishnan, A. S. (2013). Sea Level Change. In T. F. Stocker, D. Qin, G. K. Plattner, M. Tignor, S. K. Allen, J. Boschung, A. Nauels, Y. Xia, V. Bex, \& P. M. Midgley (Eds.), Climate Change 2013: The Physical Science Basis. Contribution of Working Group I to the Fifth Assessment Report of the Intergovernmental Panel on Climate Change (pp. 1137-1216). Cambridge, United Kingdom and New York: Cambridge University Press.

SPC. (2013). Gaps and needs analysis towards the development of a climate change policy framework. The Environment, Inc., Sustainable Decisions, and Partners TEI Publication\#0107131. Suva, Fiji: Pacific Community (SPC). https://www.pacificclimatechange.net/sites/default/files/documents/3.\%20Gap s\%20and\%20Needs\%20Analysis.pdf.

Crane, J. H., Salazar-Garcia, S., Lin, T. S., Pinto, A. C. Q., \& Shu, Z. H. (2009). Crop production: Management. In R. E. Litz (Ed.), The mango: Botany, production and uses (pp. 432-483). Oxfordshire, UK: CABI. 
CSIRO, Australian Bureau of Meteorology and SPREP. (2015). Climate in the Pacific: A regional summary of new science and management tools, Pacific-Australia Climate Change Science and Adaptation Planning Program Summary Report. Melbourne, Australia: Commonwealth Scientific and Industrial Research Organisation. https://www.pacificclimatechange.net/document/climate-pacific-regionalsummary-new-science-and-management-tools.

da Silva, J. A. T., Rashid, Z., Nhut, D. T., Sivakumar Gera, A., Jr Souza, M. T., \& Tenant, P. F. (2007). Papaya (Carica papaya L.) biology and biotechnology. Tree and Forestry Science and Biotechnology, 1(1), 47-73.

Dambreville, A., Normand, F., \& Lauri, P. E. (2013). Plant growth co-ordination in natura: A unique temperature controlled law among vegetative and reproductive organs in mango. Functional Plant Biology, 2013(40), 280-291.

Dar, M. H., Waza, S. A., Shukla, S., Zaidi, N. W., Nayak, S., Hossain, M., et al. (2020). Drought tolerant rice for ensuring food security in Eastern India. Sustainability, 12, 2214. https://doi.org/10.3390/ su12062214.

Daryanto, S., Wang, L., \& Jacinthe, P. A. (2016). Drought effects on root and tuber production: A metaanalysis. Agricultural Water Management, 176, 122-131.

Das, S. (2016). Amaranthus: A promising crop of future. Singapore: Springer.

Davis, R. I. (1999). Kava dieback, Pest Advisory Leaflet No. 25, Plant Protection Service, Piper methysticum, Kava - Diseases and pests - Oceania I. Secretariat of the Pacific Community II. Series III. Suva, Fiji.

Davis, R. I., \& Brown, J. F. (1999). Kava (Piper methysticum) in the South Pacific: Its importance, methods of cultivation, cultivars, diseases and pests. Canberra, Australia: Australian Centre for International Agricultural Research (ACIAR technical reports). https://ideas.repec.org/p/ags/aciatr/113917.html.

de Jesus Júnior, W. C., Júnior, R. V., Cecílio, R. A., do MoraesVale, W. B. F. X. R., Alves, F. R., \& Paul, P. A. (2008). Worldwide geographical distribution of Black Sigatoka for banana: Predictions based on climate change models. Scientia Agricola, 65, 40-53.

Deivasigamani, P., Vijayakumar, R. M., Soorianathasundaram, K., \& Santhi, R. (2019). Morphological response of polyembryonic mango rootstocks (Mangifera indica L.) to different salt levels. Journal of Pharmacognosy and Phytochemistry, 8(3), 3420-3423.

dela Cruz, F. S., van den Bergh, I., de Waele, D., Hautea, D. M., \& Molina, A. B. (2005). Towards management of Musa nematodes in Asia and the Pacific. Technical manual of the training workshop on enhancing capacity for nematode management in small scale banana cropping systems held at the Institute of Plant Breeding, Los Baños, Laguna, Philippines: University of the Philippines. https:// www.bioversityinternational.org/e-library/publications/detail/towards-management-of-musa-nemat odes-in-asia-and-the-pacific-country-reports/.

Dinh, H. T., Watanable, K., Takaragawa, H., \& Kawamitsu, Y. (2018). Effects of drought stress at early growth stage on response of sugarcane to different nitrogen application. Sugar Tech, 20, 420-430.

Downing, T. E., Olsthoorn, A. A., \& Toi, R. S. J. (2002). Climate, change and risk. New York: Routledge.

Eastburn, D. M., McElrone, A. J., \& Bilgin, D. D. (2011). Influence of atmospheric and climatic change on plant-pathogen interactions. Plant Pathology, 60, 54-69.

Edwards, D., Henry, R. J., \& Edwards, K. J. (2012). Advances in DNA sequencing accelerating plant biotechnology. Plant Biotechnology Journal, 10, 621-622.

Endo, M., Tsuchiya, T., Hamada, K., Kawamura, S., Yano, K., Ohshima, M., et al. (2009). High temperatures cause male sterility in rice plants with transcriptional alterations during pollen development. Plant and Cell Physiology, 50(11), 1911-1922.

FAO. (2008). Current status of plant genetic resources for food and agriculture: In the Republic of Fiji. Rome: Food and Agriculture Organisation of the United Nations.

FAO. (2008). Climate change and food security in Pacific Island Countries. Rome: Food and Agriculture Organization of the United Nations.

FAO. (2009). Report on the application for market access of island cabbage (Abelmoschus manihot)) from Fiji, Vanuatu, Samoa, Cook Islands and Tonga to New Zealand. Rome: Food and Agriculture Organization of the United Nations (FAO). http://www.fao.org/3/a-an430e.pdf.

FAO. (2010). Building resilience to climate change Root crop and fishery production. Rome: Food and Agriculture Organization of the United Nations.

FAO. (2012). A holistic integrated management approach to control Black Sigatoka disease of banana caused by Mycosphaerella fijiensis. Rome: Food and Agriculture Organization of the United Nations.

FAO. (2014). Tonga Cyclone Ian in Ha'apai: Rapid damage assessment to the agriculture and fisheries sectors report. Apia, Samoa: Food and Agriculture Organization of the United Nations Subregional Office for the Pacific Islands. https://reliefweb.int/report/tonga/cyclone-ian-ha-apai-rapid-damag e-assessment-agriculture-and-fisheries-sectors-report. 
FAOSTAT. (2020). Food and Agriculture Organization of the United Nations (FAO). http://www.fao.org/ faostat.

Faralli, M., Matthews, J., \& Lawson, T. (2019). Exploiting natural variation and genetic manipulation of stomatal conductance for crop improvement. Current Opinion in Plant Biology, 49, 1-7.

Fiji Bureau of Statistics. Key statistics, June, 2019. 3.3 A Primary Production; Selected Agricultural Products. https://www.statsfiji.gov.fj/index.php.

Fiji Times Online. (2017). Clean up farms to control beetle. Available at: https://www.fijitimes.com/clean -up-farms-to-control-beetle/.

Fletcher, C. H., \& Richmond, B. M. (2010). Climate change in the Federated States of Micronesia: food and water security, climate risk management and adaptive strategies. Sea Grant Report TT-10-02. Hawaii: University of Hawaii. https://pubs.er.usgs.gov/publication/70041522.

Flexas, J. (2016). Genetic improvement of leaf photosynthesis and intrinsic water use efficiency in C3 plants: Why so much little success? Plant Science, 251, 155-161.

Freeman, A., Rodoni, B., \& Taufatofua, P. (2012). Impact of climate change on food security and biosecurity of crop production systems in small pacific nations. Report. Japan: Asia-Pacific network for global change research. https://www.apn-gcr.org/resources/files/original/6ab2c34a8edf4dd6fec3 ed54a317c1c2.pdf.

Fregene, M., \& Puonti-Kaerlas, J. (2002). Cassava biotechnology. In R. J. Hillocks, J. M. Thresh, \& A. C. Bellotti (Eds.), Cassava: Biology, production and utilization (pp. 179-207). New York: CABI Publishers.

Frison, E. A., \& Feliu, E (Eds.). (1991). FAO/IBPGR technical guidelines for the safe movement of cassava germplasm. Rome, Italy: Food and Agriculture Organisation of the United Nations (FAO) and International Board for Plant Genetic Resources (IBPGR). https://www.bioversityinternatio nal.org/fileadmin/user_upload/Cassava_349.pdf.

Fullerton, R. A., Taufa, L., Vanneste, J. L., Yu, J., Cornish, D. A., \& Park, D. (2011). First record of bacterial crown rot of papaya (Carica papaya) caused by an Erwinia papayae-like bacterium in the kingdom of Tonga. Plant Disease, 95(1), 70.

Gazit, S., \& Kadman, A. (1980). 13-1 Mango rootstock selection. Horticultural Science, 15, 699.

Geetha, G. A., Shivashankara, K. S., \& Reddy, Y. T. N. (2016). Varietal variations in temperature response for hermaphrodite flower production and fruit set in mango (Mangifera indica L). South African Journal of Botany, 106, 196-203.

Ghini, R., Bettiol, W., \& Hamada, E. (2011). Diseases in tropical and plantation crops as affected by climate changes: Current knowledge and perspectives. Plant Pathology, 60, 122-132.

Gleadow, R. M., Evans, J. R., McCaffery, S., \& Cavagnaro, T. R. (2009). Growth and nutritive value of cassava (Manihot esculenta Crantz.) are reduced when grown in elevated CO2. Plant Biology, 11, 76-82.

Gleadow, R., Pegg, A., \& Blomstedt, C. K. (2016). Resilience of cassava (Manihot esculenta Crantz) to salinity: Implications for food security in low-lying regions. Journal of Experimental Botany, 67, 5403-5413.

Government of Fiji. (2009). Fiji national agricultural census. Suva, Fiji: Department of Agriculture, Economic Planning and Statistics Division.

Gomathi, R., Rao, P. N. G., Chandran, K., \& Selvi, A. (2015). Adaptive responses of sugarcane to waterlogging stress: An over view. Sugar Tech, 17, 325-338.

Gomes, F. P., \& Prado, C. H. B. A. (2007). Ecophysiology of coconut palm under water stress. Brazilian Journal of Plant Physiology, 19(4), 377-391.

Gonsalves, D. (1998). Control of papaya ringspot virus in papaya: A case study. Annual Review of Phytopathology, 36, 415-437.

Gouveia, C. S. S., Ganança, J. F. T., de Nóbrega, H. G. M., de Freita, J. G. R., Lebot, V., \& de Carvalho, M. A. A. P. (2020). Phenotypic flexibility and drought avoidance in taro (Colocasia esculenta L.). Emirates Journal of Food and Agriculture, 32(2), 150-159.

Government of Fiji. (2012). Republic of Fiji National Climate Change Policy. Suva, Fiji: Pacific Community (SPC). https://www.sprep.org/attachments/Climate_Change/Fiji-National-Climate-Change-Polic y.pdf.

Government of Samoa. (2013). SAMOA post-disaster needs assessment Cyclone Evan. Apia, Samoa: Ministry of Finance. https://www.gfdrr.org/sites/gfdrr/files/SAMOA_PDNA_Cyclone_Evan_2012.pdf.

Government of Solomon Islands (GoSI). (2008). National adaptation programme of action. Honiara, Solomon Islands: Ministry of Environment, Conservation and Meterology. https://www.prevention web.net/files/8574_solomonislands.pdf.

Guarino, L., Jackson, G. V. H. (1986). Describing and documenting root crops in the South Pacific. RAS/83/001, Field Document No 12. Suva, Fiji: UNDP/FAO. 
Guzman, M., Pérez-Vicente, L., Carlier, J., Abadie, C., de Lapoiyre, B. L., Carreel, F., et al. (2019). Black leaf streak. In D. R. Jones (Ed.), Handbook of diseases of Banana, Abacá and Enset (pp. 41-115). Oxfordshire, London: CABI.

Halewood, M., Deupmann, P., Sthapit, B. R., Vernooy, R., \& Ceccarelli, S. (2007). Participatory plant breeding to promote Farmers' Rights. Rome, Italy: Biodiversity International.

Hasan, K., Desiere, S., D'Haese, M., \& Kumar, L. (2018). Impact of climate-smart agriculture adoption on the food security of coastal farmers in Bangladesh. Food Security, 10, 1073-1088.

Hauger, J. S. (2015). Climate change challenges to security in the Pacific Islands region and opportunities for cooperation to manage the threat. In R. Azizian \& C. Cramer (Eds.), Regionalism, security and cooperation in oceania (pp. 147-160). Honolulu: Asia-Pacific Center for Security Studies.

Hebbar, K. B., Balasimha, D., \& Thomas, G. V. (2013). Plantation crops response to climate change: Coconut perspective. In H. C. P. Singh, N. K. S. Rao, \& K. S. Shivashankar (Eds.), Climate-resilient horticulture: Adaptation and mitigation strategies (pp. 177-187). India: Springer.

Hebbar, K. B., Berwal, M. K., Arivalagan, M., \& Chturvedi, V. K. (2017). Physiological and biochemical response of coconut to climate change variables. In K. B. Hebbar, S. N. Kumar, \& P. Chowdappa (Eds.), Impact of climate change on plantation crops (pp. 45-60). New Delhi: Astral International Pvt. Limited.

Helu-Thaman, K. (2008). Challenges for Pacific research: A personal view. Keynote paper presented at Building Pacific Research Capacity and Scholarship Fono 2008, Fale Pasifika, University of Auckland.

Hingley, R. (2017). 'Climate refugees': An oceanic perspective. Asia and the Pacific Policy Studies, 4, 158-165.

Hinojosa, L., Matanguihan, J. B., \& Murphy, K. M. (2018). Effect of high temperature on pollen morphology, plant growth and seed yield in quinoa (Chenopodium quinoa Willd.). Journal of Agronomy and Crop Science, 205(1), 33-45.

Hoidal, N., Díaz Gallardo, M., Jacobsen, S. E., \& Alandia, G. (2019). Amaranth as a dual-use crop for leafy greens and seeds: Stable responses to leaf harvest across genotypes and environments. Frontiers in Plant Science, 10, 817.

Howes, E. L., Birchenough, S., \& Lincoln, S. (2018). Impacts of climate change relevant to the Pacific Islands. Pacific marine climate change Report Card, Science Review. UK: Commonwealth Marine Economies Programme (CMEP). https://reliefweb.int/sites/reliefweb.int/files/resources/1_Climate_ change_overview.pdf.

Hunter, D. G., Iosefa, T., Charles, J. D., \& Fonoti, P. (2000). Beyond taro leaf blight: A participatory approach for plant breeding and selection for taro improvement in Samoa. In Proceedings of the international symposium on participatory plant breeding and participatory plant genetic resources enhancement (pp. 219-227). Pokhara, Nepal, 1-5 May 2000. Cali, Colombia: CIAT.

Hunter, D., Pouono, K., \& Semisi, S. (1998). The impact of taro leaf blight in the pacific islands with special reference to Samoa. Journal of South Pacific Agriculture, 5, 44-56.

Hussain, S., Jun-hua, Z., Chu, Z., Lian-feng, Z., Xiao-chuang, C., Sheng-miao, Y. U., et al. (2017). Effects of salt stress on rice growth, development characteristics, and the regulating ways: A review. Journal of Integrative Agriculture, 16(11), 2357-2374.

Hussain, S., Khaliq, A., Mehmood, U., Saqib, Q. M., Iqbal, M. A., \& Hussain, S. (2018). Sugarcane production under changing climate Effects of environmental vulnerabilities on sugarcane diseases, insects and weeds. In S. Hussain (Ed.), Climate change and agriculture. Intech Open: UK.

Iese, V., Halavatau, S., de Ramon N'Yeurt, A., Wairiu, M., Holland, E., Dean, A., et al. (2020). Agriculture under a changing climate. In L. Kumar (Ed.), Climate change and impacts in the Pacific (pp. 359-402). Switzerland: Springer.

Iese, V., Holland, E., Wairiu, M., Havea, R., Patolo, S., Nishi, M., et al. (2018). Facing food security risks: The rise and rise of the sweet potato in the Pacific Islands. Global Food Security, 18, 48-56.

Iese, V., Maeke, J., Holland, E., Wairiu, M., \& Naidu, S. (2015). Farming adaptations to the impacts of climate change and extreme events in Pacific Island countries. In W. G. Ganpat \& W. A. P. Isaac (Eds.), Impacts of climate change on food security in Small Island developing states (pp. 166-194). Hershey: IGI Global.

Ile, E. I., Craufurd, P. Q., Battey, N. H., \& Asiedu, R. (2006). Phases of dormancy in yam tubers (Dioscorea rotundata). Annals of Botany, 97(4), 497-504.

ILO. (2016). ILO Assessment Report: Community based emergency employment - Nabulini, Manu and Naibita Village, Tailevu, Fiji. Geneva, Switzerland: International Labour Organisation (ILO). https ://www.ilo.org/wcmsp5/groups/public/---asia/---ro-bangkok/---ilo-suva/documents/projectdocument ation/wcms_459454.pdf. 
Iosefa T. L., Taylor, M., Hunter, D., \& Tuia, V. (2012).The taro improvement programme in Samoa: sharing genetic resources through networking. In Plant Genetic Resources for Food and Agriculture in Asia and the Pacific: Impacts and future directions. Proceedings of a symposium held in Tsukuba, Japan (pp. 25-40). Bangkok, Thailand: FAO Regional Office for Asia and the Pacific.

Iyer, C. P. A. (1991). Recent advances in varietal improvement in mango. Acta Horticulturae, 291, $107-111$.

Iyer, C. P. A., \& Dinesh, M. R. (1997). Advances in classical breeding and genetics in mango. Acta Horticulturae, 455, 252-267.

Iyer, C. P. A., \& Kurian, R. M. (1992). Tree size control in mango (Mangifera indica L.): Some considerations. Acta Horticulturae, 321, 425-436.

Jackson, G. (2017). Papaya crown rot. Pacific Pests and Pathogens: Fact Sheets. Canberra, Australia: Australian Centre for International Agricultural Research ACIAR.

Jagadish, S. V. K., Craufurd, P. Q., \& Wheeler, T. R. (2008). Phenotyping parents of mapping populations of rice (Oryza sativa L.) for heat tolerance during anthesis. Crop Science, 48, 1140-1146.

Janick, J., \& Paull, R. E. (2008). The Encyclopedia of fruit and nuts. Oxfordshire, UK: CABI.

Jeger, M., Bragard, C., Caffier, D., Candresse, T., Chatzivassiliou, E., Dehnen-Schmutz, K., et al. (2017). Scientific opinion on the pest risk assessment of Radopholus similis for the EU territory. EFSA Journal, 15(8), 4879. https://doi.org/10.2903/j.efsa.2017.4879.

Jørgensen, K., Bak, S., Busk, P. K., Sørensen, C., Olsen, C. E., PuontiKaerlas, J., \& Møller, B. L. (2005). Cassava plants with a depleted cyanogenic glucoside content in leaves and tubers. Distribution of cyanogenic glucosides, their site of synthesis and transport, and blockage of the biosynthesis by RNA interference technology. Plant Physiology, 139, 363-374.

Jupiter, S., Mangubhai, S., \& Kingsfrd, R. T. (2014). Conservation of biodiversity in the Pacific Islands of Oceania: Challenges and opportunities. Pacific Conservation Biology, 20, 206-220.

Kalleshwaraswamy, C. M., Krishnakumar, N. K., Verghese, A., Dinesh, M. R., Ranganath, H. R., \& Venugopalan, R. (2007). Role of transient aphid vectors on the temporal spread of papaya ringspot virus in South India. Acta Horticulturae, 740, 251-258.

Kambuou, R. N. (1995). Papua New Guinea: Country report to the FAO international technical conference on plant genetic resources (Leipzig, 1996). Konedobu, PNG. http://www.fao.org/fileadmin/templates/ agphome/documents/PGR/SoW1/asia/PAPUANEW.pdf.

Kang, C., Zhai, H., He, S., Zhao, N., \& Liu, Q. (2019). A novel sweet potato bZIP transcription factor gene, IbbZIP1, is involved in salt and drought tolerance in transgenic Arabidopsis. Plant Cell Reports, 38, 1373-1382.

Katrodia, J. S., \& Sheth, I. K. (1989). Spongy tissue development in mango fruit of cultivar Alphonso in relation to temperature and its control. Acta Horticulturae, 231(50), 827-834.

Kenyon, L., Lebas, B. S. M., \& Seal, S. E. (2008). Yams (Dioscorea spp.) from the South Pacific Islands contain many novel badna viruses Implications for international movement of yam germplasm. Archives of Virology, 153(5), 877-889.

Kirch, P. V. (2000). On the road of the winds: An archaeological history of the Pacific Islands before European contact. Berkeley: University of California Press.

Korres, N. E., Norsworthy, J. K., Burgos, R., \& Oosterhuis, D. M. (2017). Temperature and drought impacts on rice production: An agronomic perspective regarding short and long-term adaptation measures. Water Resources and Rural Development, 9, 12-27.

Kumar, G. R., Sakthivel, K., Sundaram, R. M., Neeraja, C. N., Balachandran, S. M., Rani, N. S., et al. (2010). Allele mining in crops: Prospects and potentials. Biotechnology Advances, 28(4), 451-461.

Kumar, S. N., \& Aggarwal, P. K. (2013). Climate change and coconut plantations in India: Impacts and potential adaptation gains. Agricultural Systems, 117, 45-54.

Kumar, V. (2017). \$393k support for sustainable agriculture. The Fiji Times, https://www.fijitimes.com. fj/393k-support-for-sustainable-agriculture/.

Labouisse, J. P., Sileye, T., Bonnot, F., \& Baudouin, L. (2011). Achievements in breeding coconut hybrids for tolerance to coconut foliar decay disease in Vanuatu South Pacific. Euphytica, 177(1), 1-13.

Lal, P. N., Rita, R., \& Khatri, N. (2009). Economic Costs of the 2009 Floods in the Fiji Sugar Belt and Policy Implications. Gland, Switzerland: IUCN.

Lander, M. A. (2004). Rainfall climatology for Saipan: Distribution, return-periods, El Niño, tropical cyclones, and long-term variations. Guam: Water and Environmental Research Institute of the Western Pacific, University of Guam. https://guamhydrologicsurvey.uog.edu/Library/PDFs/WERI\%20 TR\%20103\%20-\%20Lander\%202004.pdf.

Lanning, S. B., Siebenmorgen, T. J., Counce, P. A., Ambardekar, A. A., \& Mauromoustakos, A. (2011). Extreme nighttime air temperatures in 2010 impact rice chalkiness and milling quality. Field Crops Research, 124(1), 132-136. 
Larson, K. D., Davies, F. S., \& Schaffer, B. (1991). Floodwater temperature and stem lenticel hypertrophy in Mangifera indica (Anacardiaceae). American Journal of Botany, 78(10), 1397-1403.

Lawson, T., Kramer, D. M., \& Raines, C. A. (2012). Improving yield by exploiting mechanisms underlying natural variation of photosynthesis. Current Opinion in Biotechnology, 23(2), 215-220.

Lebot, V. (2009). Tropical root and tuber crops: Cassava, sweet potato, yams and aroids. Oxfordshire, UK: CABI.

Lebot, V., Abraham, K., Kaoh, J., Rogers, C., \& Molisalé, T. (2019). Development of anthracnose resistant hybrids of the Greater Yam (Dioscorea alata L.) and interspecific hybrids with D. nummularia Lam. Genetic Resources and Crop Evolution, 66(4), 871-883.

Lebot, V., Ivancic, A., \& Abraham, K. (2005). The geographical distribution of allelic diversity, a practical means of preserving and using minor root crop genetic resources. Experimental Agriculture, 41(4), 475-489.

Lebot, V., Simeoni, P., \& Jackson, G. (2001). Networking with food crops; a new approach in the Pacific. In K. F. Wells \& K. G. Eldridge (Eds.), Plant genetic resources in the Pacific: Towards regional cooperation in conservation and management (pp. 82-85). Canberra, Australia: ACIAR.

Lee, K. J., Yoo, S. H., Park, S. W., Lee, S. J., Suriyapananont, V., \& Namuco, L. O. (2008). Effects of 2004-sunami on the changes from 2005 to 2006 in salinity of soil profiles and groundwater wells and on mortality of garden fruit trees in Maldives. Forest Science and Technology, 4(1), 14-27.

Lehmann, P., Ammunét, T., Barton, M., Battisti, A., Eigenbrode, S. D., Jepsen, J. U., et al. (2020). Complex responses of global insect pests to climate warming. Frontiers in Ecology and Environment, 18(3), $141-150$.

Li, J., Liu, L., \& Zhou, H. (2018). Improved viability of Areca (Areca catechu L.) seedlings under drought stress using a superabsorbent polymer. HortScience, 53(12), 1872-1876.

Lightfoot, C. (1999). Regional El Niño social and economic drought impact assessment and mitigation study. Suva, Fiji: Disaster Management Unit (DMU), South Pacific Geoscience Commission (SOPAC). http://sopaccompendium.spc.int/data/Reports/TR0303.pdf.

Lim, T. K. (2014). Edible medicinal and non-medicinal plants. Netherlands: Springer.

Lima Neto, A. J., Cavalcante, L. F., Mesquita, F. O., Souto, A. G. L., Santos, G. P., Santos, J. Z., \& Mesquita, E. F. (2016). Papaya seedlings irrigation with saline water in soil with bovine biofertilizer. Chilean Journal of Agricultural Research, 76(2), 236-242.

Lingle, S. E., \& Wiegand, C. L. (1997). Soil salinity and sugarcane juice quality. Field Crops Research, 54(2-3), 259-268.

Liyanage, A., \& de Misipati, P. S. (1993). Sustainable management practices of taro (Colocasia esculenta) production in Western Samoa. In L. Ferentinos (Ed.), Proceedings of the sustainable taro culture for the Pacific Conference (pp. 79-83). Sustainable Taro Culture for the Pacific Conference, September 24-25, 1992, Honolulu, Hawaii. Honolulu: University of Hawaii. https://www.ctahr.hawaii.edu/oc/ freepubs/pdf/RES-140-20.pdf.

Lyman, N. B., Jagadish, K. S. V., Nalley, L. L., Dixon, B. L., \& Siebenmorgen, T. (2013). Neglecting rice milling yield and quality underestimates economic losses from high-temperature stress. PLoS ONE, 8(8), e72157. https://doi.org/10.1371/journal.pone.0072157.

Lyons, G., Goebel, R., Tikai, P., Stanley, K. J., \& Taylor, M. (2015). Promoting nutritious leafy vegetables in the Pacific and Northern Australia. Acta Horticulturae, 1102, 253-260. https://doi.org/10.17660/ ActaHortic.2015.1102.31.

Mabhaudhi, T., Chimonyo, V. G. P., Hlahla, S., Massawe, F., Mayes, S., Nhamo, L., \& Modi, A. T. (2019). Prospects of orphan crops in climate change. Planta, 250, 695-708.

Mabhaudhi, T., Chimonyo, V. G. P., \& Modi, A. T. (2017). Status of underutilised crops in South Africa: Opportunities for developing research capacity. Sustainability, 9, 1569. https://doi.org/10.3390/su909 1569.

Mace, E. S., Mathur, P. N., Izquierdo, L., Hunter, D., Taylor, M. B., Singh, D., et al. (2006). Rationalization of taro germplasm collections in the Pacific Island region using simple sequence repeat (SSR) markers. Plant Genetic Resources, 4, 210-220.

Macfadyen, S., Paull, C., Boykin, L., de Barro, P., Maruthi, M., Otim, M., et al. (2018). Cassava whitefly, Bemisia tabaci (Gennadius) (Hemiptera: Aleyrodidae) in East African farming landscapes: A review of the factors determining abundance. Bulletin of Entomological Research, 108(5), 565-582.

Mael, H. S. (2013). Climate change and agriculture in Vanuatu: A study of crops and farming system. Rome: Food and Agriculture Organization of the United Nations.

Marler, T., DeMeo, R. A., \& Lawton, P. D. (1996). Leaf physiology and drought stress of two Pandanus species in a humid lowland tropical climate. Journal of Tropical Forest Science, 9(1), 110-123.

Marshall, S. D. G., Moore, A., \& Vaqalo, M. (2016). A new coconut rhinoceros beetle biotype threatens coconut and oil palms in Southeast Asia and the Pacific. University of Guam 
Masson-Delmotte, V., Zhai, P., Pörtner, H. O., Roberts, D., Skea, J., Shukla, P. R., Pirani, A., MoufoumaOkia, W., Péan, C., Pidcock, R., Connors, S., Matthews, J. B. R., Chen, Y., Zhou, X., Gomis, M. I., Lonnoy, E., Maycock, T., Tignor, M., \& Waterfield, T. (Eds.). (2018). Global Warming of $1.5^{\circ} \mathrm{C}$. An IPCC Special Report on the impacts of global warming of $1.5^{\circ} \mathrm{C}$ above pre-industrial levels and related global greenhouse gas emission pathways, in the context of strengthening the global response to the threat of climate change, sustainable development, and efforts to eradicate poverty. Geneva, Switzerland: Intergovernmental Panel on Climate Change (IPCC). https://www.ipcc.ch/sr15/.

Masters, G., \& Norgrove, L. (2010). Climate change and invasive alien species. CABI Working Paper 1. https://www.cabi.org/Uploads/CABI/expertise/invasive-alien-species-working-paper.pdf.

Mbow, C., Noordwijk, M. V., Luedeling, E., Neufeldt, H., Minang, P. A., \& Kowero, G. (2014). Agroforestry solutions to address food security and climate change challenges in Africa. Current Opinion in Environmental Sustainability, 6, 61-67.

McGregor, A., Bourke, R. M., Manley, M., Tubuna, S., \& Deo, R. (2009). Pacific island food security: Situation, challenges and opportunities. Pacific Economic Bulletin, 24(2), 1-19.

McGregor, A., Kaoh, P., Mariner, L. T., Lal, P. N., \& Taylor, M. (2011). Assessing the social and economic value of germplasm and crop improvement as a climate change adaptation strategy: Samoa and Vanuatu case studies. A background case study prepared for IUCN's report, Climate Change Adaptation in the Pacific: Making Informed Choices, prepared for the Australian Department of Climate Change and Energy Efficiency (DCCEE). Suva, Fiji: IUCN.

McGregor, A., \& McGregor, K. L. (1999). Disasters and agriculture in the Pacific Islands. New York, USA: United Nations Development Programme (UNDP). https://nab.vu/sites/default/files/nab/ documents/14/01/2013\%20-\%2007\%3A47/1999_spdrp_pacific_disasters_agriculture.pdf.

McGregor, A., \& Sheehy, M. (2019). Food security in the atoll countries of the South Pacific - with particular reference to Tuvalu: a report prepared for IFAD to assist in the preparation of funding proposal to the Global Agriculture and Food Security Program. Rome, Italy: International Fund for Agricultural Development (IFAD). https://www.gafspfund.org/sites/default/files/inline-files/ Note\%202.\%20Multi-country_GAFSP\%20SIFWaP\%20Tuvalu\%20Market\%20Study.pdf.

McLean, K. G., \& Heckler, S. (2017). Towards climate change resilience: Minimizing loss and damage in Pacific SIDS communities. Apia Samoa: UNESCO.

McNamara, K. E., \& Combes, H. J. D. (2015). Planning for community relocations due to climate change in Fiji. International Journal of Disaster Risk Science, 6(3), 315-319.

Mertz, O., Birch-Thomsen, T., Elberling, B., Rothausen, S., Bruun, T. B., Reenberg, A., et al. (2012). Changes in shifting cultivation systems on small Pacific Islands. The Geographical Journal, $178(2), 175-187$.

Mimura, N. (1999). Vulnerability of island countries in the South Pacific to sea level rise and climate change. Climate Research, 12, 137-143.

Ministry of Agriculture. (2006). Root crop varieties to grow under extreme conditions in Fiji. SPC/GIZ Coping with climate change in the Pacific Island Region Programme. Suva, Fiji: Ministry of Agriculture. https://pafpnet.spc.int/attachments/article/749/Resilientcrops2006.pdf.

Ministry of Primary Industries (MPI). (2012). Agriculture investment guide: discovering opportunities harvesting potentials. Suva, Fiji: Ministry of Primary Industries. https://pafpnet.spc.int/attachment s/article/740/FJ-IGuide.pdf.

Misra, V., Solomon, S., Mall, A. K., Prajapati, C. P., Hashem, A., Abd-Allah, E. F., \& Ansari, M. I. (2020). Morphological assessment of water stressed sugarcane: A comparison of waterlogged and drought affected crop. Saudi Journal of Biological Sciences, 27(5), 1228-1236.

Miyasaka, S. C., Hamasaki, R. T., \& Pena, R. S. (2002). Nutrient Deficiencies and Excesses in Taro. Honolulu, Hawaii: College of Tropical Agriculture \& Human Resources, University of Hawaii at Manoa. https://www.ctahr.hawaii.edu/oc/freepubs/pdf/SCM-4.pdf.

Morita, S., Wada, H., \& Matsue, Y. (2016). Counter measures for heat damage in rice grain quality under climate change. Plant Production Science, 19(1), 1-11.

Muimba-Kankolongo, A. (2018). Food crop production by smallholder farmers in Southern Africa challenges and opportunities for improvement. London: Academic Press.

Murakami, H., Delworth, T. L., Cooke, W. F., Zhao, M., Xiang, B., \& Hsu, P. C. (2020). Detected climatic change in global distribution of tropical cyclones. Proceedings of the National Academy of Sciences (PNAS), 117(20), 10706-10714.

Murphy, B. F., Power, S. B., \& McGree, S. (2014). The varied impacts of El Nino Southern Oscillation on Pacific Island climates. Journal of Climate, 27(11), 4015-4036.

Murukesan, V. K., van den Berg, E., Tiedt, L. R., Josekutty, P. C., \& de Waele, D. (2005). Corm rot of giant swamp taro (Cyrtosperma merkusii) caused by the burrowing nematode Radopholus similis 
(Nematoda: Pratylenchidae). International Journal of Fundamental and Applied Nematological Research, 7(4), 631-636.

Myers, S. S., Wessells, K. R., Kloog, I., Zanobetti, A., \& Schwartz, J. (2015). Effect of increased concentrations of atmospheric carbon dioxide on the global threat of zinc deficiency: A modeling study. The Lancet. Global Health, 3(10), e639-e645.

Myers, S. S., Zanobetti, A. I., Kloog, P., Huybers, A. D., Leakey, A. J., Bloom, E., et al. (2014). Increasing $\mathrm{CO}_{2}$ threatens human nutrition. Nature, 510, 139-142.

Nassar, N. M. A., Graciano-Ribeiro, D., Gomes, P. F., \& Hashimoto, D. Y. C. (2010). Alterations of reproduction system in a polyploidized cassava interspecific hybrid. Hereditas, 147, 58-61.

Nath, V., Kumar, G., Pandey, S. D., \& Pandey, S. (2018). Impact of climate change on tropical fruit production systems and its mitigation strategies. In S. S. Mahdi (Ed.), Climate change and agriculture in India: Impact and adaptation (pp. 129-146). Switzerland: Springer International Publishing.

National Research Council (NRC). (1984). Amaranth: Modern prospects for an ancient crop. Washington, DC: The National Academies Press.

Neba, A. G., Ndonwi, A. S., \& Mimba, A. (2014). Impacts of climate variability and change on banana yields in the CDC-Delmonte Banana Project, Tiko, South West Region, Cameroon. Journal of the Cameroon Academy of Sciences, 11(2 \& 3), 131-142.

Neela, S., \& Fanta, S. W. (2019). Review on nutritional composition of orange-fleshed sweet potato and its role in management of vitamin A deficiency. Food Science and Nutrition, 7(6), 1920-1945.

Nelson, S. C. (2008). Mango anthracnose (Colletotrichum gloeosporioides). Honolulu, Hawaii: College of Tropical Agriculture \& Human Resources, University of Hawaii at Manoa. https://www.ctahr .hawaii.edu/oc/freepubs/pdf/pd-48.pdf.

Nelson, S. C. (2011). Farm and forestry production and marketing profile for Kava (Piper methysticum). In C. R. Elevitch (Ed.), Specialty crops for Pacific Island Agroforestry. Holualoa Hawaii: Permanent Agriculture Resources (PAR).

Neville, R. (2014). Current forest conditions in the US-Affiliated Pacific Islands. USDA Forest Service, Pacific Islands Forest Health Report. https://www.fs.usda.gov/Internet/FSE_DOCUMENTS/stelp rd3819159.pdf.

Nishina, M., Zee, F., Ebseu, R., Arakabi, A., Hamasaki, R., Fukuda, S., Nagata, N., Chia, C. L., Nishijima, W., Mau, R., \& Uchida, R. (2000). Papaya production in Hawaii. Honolulu, Hawaii: College of Tropical Agriculture and Human Resources (CTAHR), University of Hawaii at Manoa. https://www.ctahr .hawaii.edu/oc/freepubs/pdf/F_N-3.pdf.

Nishiuchi, S., Yamauchi, T., Takahashi, H., Kotula, L., \& Nakazono, M. (2012). Mechanisms for coping with submergence and waterlogging in rice. Rice, 5, 2. https://doi.org/10.1186/1939-8433-5-2.

Niyongere, C., Losenge, T., Ateka, E. M., Ntukamazina, N., Ndayiragije, P., Simbare, A., et al. (2013). Understanding banana bunchy top disease epidemiology in Burundi for an enhanced and integrated management approach. Plant Pathology, 62, 562-570.

Normand, F., Lauri, P. E., \& Legave, J. M. (2015). Climate Change and its probable effects on mango production and cultivation. Acta Horticulturae, 1075, 21-31.

O'Sullivan, J. N. (2010). Yam nutrition: nutrient disorders and soil fertility management. ACIAR Monograph No. 144. Canberra, Australia: ACIAR. https://aciar.gov.au/node/10011.

Ohshiro, M., Amzad, H. M., Ichiro, N., Hikaru, A., Masanobu, T., Chitta, B. P., \& Akihiro, N. (2016). Effects of soil types and fertilizers on growth, yield, and quality of edible Amaranthus tricolor lines in Okinawa, Japan. Plant Production Science, 19, 61-72.

Okada, Y., Monden, Y., Nokihara, K., et al. (2019). Genome-Wide Association Studies (GWAS) for Yield and Weevil Resistance in Sweet potato (Ipomoea batatas (L.) Lam). Plant Cell Reports, 38, 13831392. https://doi.org/10.1007/s00299-019-02445-7.

Oki, N., Kaga, A., Shimizu, T., Takahashi, M., Kono, Y., \& Takahashi, M. (2017). QTL mapping of antixenosis resistance to common cutworm (Spodoptera litura Fabricius) in wild soybean (Glycine soja). PLoS ONE, 12(12), e0189440. https://doi.org/10.1371/journal.pone.0189440.

Oladosu, Y., Rafii, M. Y., Arolu, F., Chukwu, S. C., Muhammad, I., Kareem, I., et al. (2020). Submergence tolerance in rice: Review of mechanism, breeding and future prospects. Sustainability, 12, 1632. https ://doi.org/10.3390/su12041632.

Olesen, T. (2011). Late 20th century warming in a coastal horticultural region and its effects on tree phenology. New Zealand Journal of Crop and Horticultural Science, 39(2), 119-129.

Onwueme, I. (1999). Taro cultivation in Asia and the Pacific. Bangkok, Thailand: Food and Agriculture Organization of the United Nations Regional Office for Asia and the Pacific. http://ebooks.lib.ntu.edu. tw/1_file/FAO/67652/ac450e00.pdf.

Onwueme, I. C., \& Charles, W. B. (1994). Tropical root and tuber crops: Production, perspectives and future prospects. Rome: Food and Agriculture Organisation of the United Nations. 
Oppenheimer, M., Glavovic, B., Hinkel, J., van de Wal, R., Magnan, A. K., Abd-Elgawad, A., Cai, R., Cifuentes-Jara, M., DeConto, R. M., Ghosh, T., Hay, J., Isla, F., Marzeion, B., Meyssignac, B., \& Sebesvari, Z. (2019). Sea level rise and implications for low lying islands, coasts and communities. In H. O. Pörtner, D.C. Roberts, V. Masson-Delmotte, P. Zhai, M. Tignor, E. Poloczanska, K. Mintenbeck, A. Alegría, M. Nicolai, A. Okem, J. Petzold, B. Rama, \& N.M. Weyer (Eds.), IPCC Special Report on the Ocean and Cryosphere in a Changing Climate. In Press.

Osborne, T. (2005). Research on coconut genetic resources in the South Pacific. In P. Batugal, V. R. Rao, \& J. Oliver (Eds.), Coconut Genetic Resources (pp 513-523). Serdang, Malaysia: International Plant Genetic Resources Institute Regional Office for Asia, the Pacific and Oceania (IPGRI-APO). https ://www.bioversityinternational.org/fileadmin/_migrated/uploads/tx_news/Coconut_genetic_resou rces_1112.pdf.

Secretariat of the Pacific Regional Environment Programme (SPREP). (2008). Pacific Climate Change. SPREP Factsheet No. PF-003. https://www.sprep.org/attachments/Publications/FactSheet/pacificcli mate.pdf.

Pacific horticultural and agricultural market access (PHAMA). (2017). Fiji Kava Quality Manual. Suva, Fiji: Pacific Horticultural and Agricultural Market Access (PHAMA). https://pafpnet.spc.int/attac hments/article/779/Fiji-Kava-Quality-Manual.pdf.

Palanivel, H., Puran, K., Kumar, R., Kumar, S., \& Nath, P. (2016). Study on physicochemical properties of rice varieties in Fiji. Journal of Agricultural Science, 8(4), 101-105.

Paredes-Lopez, O. (Ed.). (2017). Amaranth biology, chemistry, and technology. Boca Raton, FL: CRC Press.

Parés, J., \& Basso, C. (2013). Effect of sodium chloride on growth and mineral content of papaya plant. Bioagro, 25(2), 109-116.

Parkinson, S. (1990). Food intake. In A. A. J. Jansen, S. Parkinson, \& A. F. S. Robertson (Eds.), Food and nutrition in Fiji: a historical review (Vol. 1). Suva, Fiji: University of the South Pacific.

Parmesan, C., Ryrholm, N., Stefanescu, C., Hill, J. K., Thomas, C. D., Descimon, H., et al. (1999). Poleward shifts in geographical ranges of butterfly species associated with regional warming. Nature, 399, 579-583.

Pathmeswaran, C., Lokupitiya, E., Waidyarathne, K. P., \& Lokupitiya, R. S. (2018). Impact of extreme weather events on coconut productivity in three climatic zones of Sri Lanka. European Journal of Agronomy, 96, 47-53.

Patindol, J. A., Siebenmorgen, T. J., Wang, Y. J., Lanning, S. B., \& Counce, P. A. (2014). Impact of elevated nighttime air temperatures during kernel development on starch properties of field-grown rice. Cereal Chemistry Journal, 91, 350-357.

Paull, R. E., \& Duarte, O. (2011). Tropical fruits. Oxfordshire, UK: CABI.

Pelemo, O., Benjamin, G., Adejumobi, I., Olusola, T., Odom-Kolombia, O., Adeosun, T., et al. (2019). Semi-Autotrophic Hydroponics: A potential seed system technology for reducing the breeding cycle and rapid quality seed delivery. Ibadan, Nigeria: International Institute of Tropical Agriculture.

PestNet. (2020). Phellinus noxius, breadfruit, Pohnpei, FSM. http://www.pestnet.org/.

Plucknett, D. L. (1977). Giant swamp taro, a little-known Asian-Pacific food crop. In J. Cock, R. MacIntyre, \& M. Graham (Eds.), Proceedings of the 4th symposium of the International Society for Tropical Root Crops (pp. 36-40), Ottawa, Canada: International Development Research Centre.

Pobar, R. A., Balo, E., \& Pobar, M. S. (2014). Acceptability of value-added products from giant swamp taro (Cystosperma chamissonis) corm. International Journal of Environmental and Rural Development, 5(1), 136-141.

Prasad, P. V. V., Boote, K. J., Allen, L., \& Hartwell, L. A., Jr. (2006). Adverse high temperature effects on pollen viability, seed-set, seed yield and harvest index of grain-sorghum [Sorghum bicolor (L.) Moench] are more severe at elevated carbon dioxide due to higher tissue temperatures. Agricultural and Forest Meteorology, 139, 237-251.

Preston, S.R. (1998). Aibika/Bele. Abelmoschus manihot (L.) Medik. Promoting the conservation and use of underutilized and neglected crops. Rome, Italy: International Plant Genetic resources Institute. https://www.bioversityinternational.org/fileadmin/user_upload/online_library/publications/ pdfs/468.pdf.

Pushpa, R. N., Nagaraju, N., Joshi, S., \& Jagadish, K. S. (2019). Epidemiology of Papaya Ringspot Virus-P (PRSVP) infecting papaya (Carica papaya Linn.) and influence of weather parameters on population dynamics of predominant aphid species. Journal of Entomology and Zoology Studies, 7(2), 434-439.

Qvenild, R. (2012). Svalbard Global Seed Vault. In L. Kotze, S. Morse, \& I. Krasnova (Eds.), The Berkshire encyclopedia of sustainability: Afro-Eurasia: Assessing sustainability (pp. 303-306). Massachusetts, USA: Berkshire Publishing Group. 
Ragone, D. (2011). Farm and forestry production and marketing profile for breadfruit (Artocarpus altilis). In C. R. Elevitch (Ed.), Specialty crops for Pacific Island agroforestry (pp. 61-78). Holualoa, Hawaii: Permanent Agriculture Resources (PAR).

Ranasinghe, C. S., Silva, L. R. S., \& Premasiri, R. D. N. (2015). Major determinants of fruit set and yield fluctuation in coconut (Cocos nucifera L.). Journal of National Science Foundation of Sri Lanka, 43(3), 253-264.

Rao, S., Taylor, M., \& Jokhan, A. (2014). In vivo screening of salinity tolerance in Giant Swamp Taro (Cyrtosperma merkusii). The South Pacific Journal of Natural and Applied Sciences, 32, 33-36.

Rastogi, A., \& Shukla, S. (2013). Amaranth: A new millennium crop of nutraceutical values. Critical Reviews in Food Science and Nutrition, 53(2), 109-125.

Rauka, G. B., \& Shigaki, T. (2015). Occurrence and distribution of Aibika (Abelmoschus manihot (L.) Medik.) collar rot and Fusarium rot in Morobe Province Papua New Guinea. Fiji Agricultural Journal, 55(1), 4-10.

Ravi, I., Uma, S., Vaganan, M. M., \& Mustaffa, M. M. (2013). Phenotyping bananas for drought resistance. Frontiers in Physiology, 4, 1-9.

Raynor, B., Lorens, A., \& Phillip, J. (1992). Traditional yam cultivation on Pohnpei, Eastern Caroline Islands Micronesia. Economic Botany, 46(1), 25-33.

Raza, A., Razzaq, A., Mehmood, S. S., Zou, X., Zhang, X., Lv, Y., \& Xu, J. (2019). Impact of climate change on crops adaptation and strategies to tackle its outcome: A review. Plants (Basel), 8(2), 34.

Razzaq, A., Ali, A., Safdar, L. B., Zafar, M. M., Rui, Y., Shakeel, A., et al. (2019). Salt stress induces physiochemical alterations in rice grain composition and quality. Journal of Food Science, 85(1), 14-20.

Republic of Palau. (2013). Second National Communication to the United Nations Framework Convention on Climate Change. https:/www4.unfccc.int/sites/SubmissionsStaging/NationalReports/ Documents/45823961_Palau-NC2-1-Final_Palau\%20Nationa1\%20Communication.pdf.

Reynolds, M. P., Hays, D., \& Chapman, S. (2010). Breeding for adaptation to heat and drought stress. In M. P. Reynolds (Ed.), Climate change a crop production (pp. 71-91). Wallingford, UK: CABI.

Richardson, K. V., \& Calligiri, P. D. S. (2014). Calcium chloride and salinity stress effects on growth, dry matter allocation and ion uptake of sweet potato (Ipomoea batatas [L.] Lam.). Journal of Root Crops, 40, 56-65.

Roberts-Nkrumah, L. B. (2015). Breadfruit and breadnut orchard establishment and management: A manual for commercial production. Rome: Food and Agriculture Organization of the United Nations (FAO).

Rosegrant, M. W., Valmonte-Santos, R., Thomas, T., You, L., \& Chiang, C. (2015). Climate change, food security, and socioeconomic livelihood in Pacific Islands. Asian Development Bank and IFPRI. https ://www.adb.org/sites/default/files/publication/175046/climate-change-food-security-pacific.pdf.

Roullier, C., Rossel, G., Tay, D., Mckey, D., \& Lebot, V. (2011). Combining chloroplast and nuclear microsatellites to investigate origin and dispersion of new world sweet potato landraces. Molecular Ecology, 20(19), 3963-3977.

Rubiang-Yalambing, L., Arcot, J., Greenfield, H., \& Holford, P. (2016). Aibika (Abelmoschus manihot L.): Genetic variation, morphology and relationships to micronutrient composition. Food Chemistry, 193, $62-68$.

Sabiiti, G., Ininda, J. M., Ogallo, L., Opijah, F., Nimusiima, A., Otieno, G., et al. (2016). Empirical relationship between banana yields and climate variability over Uganda. Journal of Environmental and Agricultural Sciences, 7, 3-13.

Sahoo, M. R., Dasgupta, M., Kole, P. C., \& Mukherjee, A. (2018). Photosynthetic, physiological and biochemical events associated with polyethylene glycol-mediated osmotic stress tolerance in taro (Colocasia esculenta L. Schott). Photosynthetica, 56, 1069-1080.

Saikumar, S., Varma, C. M. K., Saiharini, A., Kamleshwar, G. P., Nagendra, K., Lavanya, K., \& Ayyappa, D. (2016). Grain yield responses to varied level of moisture stress at reproductive stage in an interspecific population derived from Swarna/O. glaberrima introgression line. NJAS-Wageningen Journal of Life Sciences, 78(9), 111-122.

Sardos, J., McKey, D., Duval, M. F., Malapa, R., Noyer, J. L., \& Lebot, V. (2008). Evolution of cassava (Manihot esculenta Crantz) after recent introduction into a South Pacific Island system: The contribution of sex to the diversification of a clonally propagated crop. Genome, 51, 912-921.

Sarker, U., Islam, T., \& Oba, S. (2018). Salinity stress accelerates nutrients, dietary fiber, minerals, phytochemicals and antioxidant activity in Amaranthus tricolor leaves. PLOS ONE, 13(11), e0206388. https ://doi.org/10.1371/journal.pone.0206388.

Schaffer, B., Urban, L., Lu, P., \& Whiley, A. W. (2009). Ecophysiology. In R. E. Litz (Ed.), The mango: Botany, production and uses (pp. 170-209). Oxfordshire, UK: CABI. 
Schiffman, R. (2014). An insurance policy for climate change? How seed banks are protecting the future of food. http://www.yesmagazine.org/climate-in-our-hands/insurance-policy-climate-change-seed-banks -future-of-food.

Sen, P. L. (2017). Characteristics and salinity tolerance of ten common varieties of Abelmoschus manihot (bele) in Fiji. M.Sc. dissertation. Suva, Fiji: The University of the South Pacific.

Shah, S., Moroca, A., \& Bhat, J. A. (2018). Neo-traditional approaches for ensuring food security in Fiji Islands. Environmental Development, 28, 83-100.

Shepherd, K. (1999). Cytogenetics of the genus Musa. Montpellier, France: International Network for the Improvement of Banana and Plantain.

Shu, Z. H. (1999). Effect of temperature on the flowering biology and fertilization of mangoes (Mangifera indica L.). Journal of Applied Horticulture, 1(2), 79-83.

Singh, A. (2020). Benefits of crop diversification in Fiji's sugarcane farming. Asia and the Pacific Policy Studies, 7(1), 65-80.

Singh, D., Jackson, G., Hunter, D., Fullerton, R., Lebot, V., Taylor, M., et al. (2012). Taro leaf blight: A threat to food security. Agriculture, 2, 182-203.

Singh, D., Mace, E., Okpul, T., Godwin, I., Mathur, P. N., Taylor, M. B., Kambuou, R., Rao, V. R., \& Hunter, D. (2002). Collection, characterization and conservation of taro (Colocasia esculenta) genetic resources for efficient utilization in breeding. In J. A. McComb (Ed.), Proceedings of the 12th Australasian Plant Breeding Conference (pp. 251-253). Perth, Western Australia: The Australasian Plant Breeding Association Inc.

Solomon Islands Government. (2014). Rural Development Program Phase 2 (RDP II). Environmental and Social Management Framework (ESMF). Solomon Islands: Solomon Islands Government Ministry of Development Planning and Aid Coordination.

Song, J., Klotzbach, P. J., Tang, J., \& Wang, Y. (2018). The increasing variability of tropical cyclone lifetime maximum intensity. Scientific Reports. https://doi.org/10.1038/s41598-018-35131-x.

Sousa, M. S. S., Lima, V. L. A., Brito, M. E. B., Silva, L. A., Moreira, R. C. L., \& Oliveira, C. J. A. (2019). Organic fertilization to attenuate water salinity effect on papaya growth. Revista Brasileira de Engenharia Agrícola e Ambiental, 23(2), 79-83.

SPC. (2011). Food security in the Pacific and East Timor and its vulnerability to climate change. Noumea, New Caledonia: Pacific Community

Spencer-Lopes, M. M., Forster, B.P., \& Jankuloski, L (Eds.). (2018). Manual on Mutation Breeding. Rome, Italy: Food and Agriculture Organization of the United Nations. http://www.fao.org/3/i9285en/I9285 EN.pdf.

Srivastava, K. A., Gaiser, T., Heiko, P., \& Ewert, F. (2012). The impact of climate change on Yam (Dioscorea alata) yield in the savanna zone of West Africa. Agriculture, Ecosystems and Environment, 153, 57-64.

Staples, G. W., \& Bevacqua, R. F. (2006). Areca catechu (betel nut palm), ver. 1.3. In C. R. Elevitch (Ed.), Species profiles for Pacific Island agroforestry. Holualoa Hawaii: Permanent Agriculture Resources (PAR).

Sujatha, S., Bhat, R., \& Apshara, S. E. (2018). Climate change, weather variability and associated impact on arecanut and cocoa in humid tropics of India. International Journal of Innovative Horticulture, 7(1), 27-37.

Svirskis, A. (2003). Investigation of amaranth cultivation and utilization in Lithuania. Agronomy Research, $1(2), 253-264$.

Swaminathan, M. S., \& Kesavan, P. C. (2012). Agricultural research in an era of climate change. Agricultural Research, 1(1), 3-11.

Tadele, Z., MBA, C., \& Till, B. J. (2010). Tilling for mutations in model plants and crops. In S. Jain \& D. Brar (Eds.), Molecular techniques in crop improvement (pp. 307-332). Dordrecht: Springer.

Taraken, I. T., \& Ratsch, R. (2009). Sweet potato cultivation on composted mounds in the highlands of Papua New Guinea. In G. Kirchhof (Ed.), Soil fertility in sweet potato-based cropping systems in the highlands of Papua New Guinea (pp 24-32). ACIAR Technical Reports No. 71. Canberra, Australia: ACIAR.

Taylor, M., Hunter, D., Rao, V. R., Jackson, G. V. H., Sivan, P., \& Guarino, L. (2010). Taro collecting and conservation in the Pacific Region. In V. R. Rao, P. J. Matthews, P. B. Eyzaguirre, \& D. Hunter (Eds.), The global diversity of taro ethnobotany and conservation (pp. 150-167). Italy: Biodiversity International.

Taylor, M., Lebot, V., McGregor, A., \& Redden, R. J. (2019). Sustainable production of roots and tuber crops for food security under climate change. In S. S. Yadav, R. J. Redden, J. L. Hatfield, A. W. Ebert, \& D. Hunter (Eds.), Food security and climate change (pp. 359-376). New Jersey, USA: Wiley. 
Taylor, M., McGregor, A., \& Dawson, B. (2016). Vulnerability of Pacific Island agriculture and forestry to climate change. New Caledonia: Pacific Community.

Tekinene, M. (2014). An assessment of the impacts of climate change on cultivated pulaka (Cyrtosperma chamissonis) in Tuvalu. M.Sc. Dissertation. Suva, Fiji: The University of the South Pacific.

Teves, G. I. (2016). The papaya special. Molokai native Hawaiian beginning farmer quarterly. Honolulu, Hawaii: College of Tropical Agriculture and Human Resources, University of Hawaii at Manoa. https ://gms.ctahr.hawaii.edu/gs/handler/getmedia.ashx?moid=2878\&dt=3\&g=12.

Thomas, F. (2019). Atoll archaeology in the Pacific. In C. Smith (Ed.), Encyclopedia of global archaeology. Switzerland: Springer.

Thomson, L. A. J., Englberger, L., Guarino, L., Thaman, R. R., \& Elevitch, C. (2006). Pandanus tectorius (screw pine). Species profiles for Pacific island agroforestry. Holualoa, Hawaii: Permanent Agriculture Resources (PAR).

Thornton, P., \& Cramer, L. (2012). Impacts of climate change on the agricultural and aquatic systems and natural resources within the CGIAR's mandate. Working Paper No. 23. Copenhagen, Denmark: CGIAR Research Program on Climate Change, Agriculture and Food Security (CCAFS). https://hdl. handle.net/10568/21226.

Thuy, T. C., \& Saitoh, K. (2017). Responses of fourteen Vietnamese rice (Oryza sativa L.) cultivars to high temperatures during grain filling period under field conditions. Agronomy, 7, 57. https://doi. org/10.3390/agronomy 7030057 .

Tisdell, C. (2014). Genetic erosion in traditional food crops in the Pacific Islands: background, socioeconomic causes and policy issues. Working papers on economics, ecology and the environment. Brisbane, Australia: The University of Queensland. https://econpapers.repec.org/paper/agsuqseee/16837 4.htm.

Tsatsia, H., \& Jackson, G. (2017). Mango anthracnose (009). Pacific Pests and Pathogens - Fact Sheets. Canberra, Australia: ACIAR. http://www.pestnet.org/fact_sheets/mango_anthracnose_009.pdf.

Tuia, V. S., Kambuou, R., Paofa, J., Malapa, R., Robert, N., Hadosaia, C., et al. (2015). Sustainable conservation and utilisation of bele (Abelmoschus manihot), a Pacific indigenous vegetable. Acta Horticulturae, 1102, 61-66.

Umesha, S. (2005). Plant biotechnology. New Delhi: The Energy and Resources Institute (TERI).

Umeyama, M. (2012). Shore protection against sea level rise and tropical cyclones in small island states. Natural Hazards Review, 13, 106-116.

van Asten, P. J. A., Fermont, A. M., \& Taulya, G. (2011). Drought is a major yield loss factor for rainfed East African highland banana. Agricultural Water Management, 98, 541-552.

Vandegeer, R., Miller, R. E., Bain, M., Gleadow, R. M., \& Cavagnaro, T. R. (2012). Drought adversely affects tuber development and nutritional quality of the staple crop cassava (Manihot esculenta Crantz). Functional Plant Biology, 40(2), 195-200.

Varma, V., \& Bebber, D. P. (2019). Climate change impacts on banana yields around the world. Nature Climate Change, 9(10), 752-757.

Vasantha, S., Venkataramana, S., Rao, P. N. G., \& Gomathi, R. (2010). Long term salinity effect on growth, photosynthesis and osmotic characteristics in sugarcane. Sugar Tech, 12(1), 5-8.

Vercambre, B. (2010). Biology and population dynamics of the potential sugarcane Fiji disease vector Perkinsiella saccharicida (Homoptera:Delphacidae) in Réunion: evidence of its loss of biotic potential. http://hal.cirad.fr/cirad-00482835/document.

Vernooy, R., Shrestha, P., \& Sthapit, B. (2015). Community seed banks: Origin, evolution and prospects. New York: Earthscan.

Vernooy, R., Sthapit, B., Otieno, G., Shrestha, P., \& Gupta, A. (2017). The roles of community seed banks in climate change adaption. Development in Practice, 27(3), 316-327.

Vieccelli, J. C., Araujo, L., Lopes, U. P., \& Rodrigues, F. A. (2017). Development of mango wilt in mango cultivars submitted to salt stress. Bragantia, 76, 372-377.

Wairiu, M., Lal, M., \& Iese, V. (2012). Climate change implications for crop production in Pacific Islands Region. In A. Aladjadjiyan (Ed.), Food production: Approaches, challenges and tasks (pp. 67-86). UK: Intech Open.

Wang, F., Wang, C., Liu, P., Lei, C., Hao, W., Gao, Y., et al. (2016). Enhanced rice blast resistance by CRISPR/Cas9-targeted mutagenesis of the ERF transcription factor gene OsERF922. PLoS ONE. https://doi.org/10.1371/journal.pone.0154027.

Wang, S.T., \& Ebert, A.W. (2012). Breeding of leafy amaranth for adaptation to climate changes. In R. Homer, G. Linwattana, P. Nath, \& J.D.H. Keatinge (Eds.), High value vegetables in Southeast Asia: Production, supply and demand (pp. 36-43). SEAVEG2012 Regional Symposium, 24-26 January, 2012, Thailand. http://203.64.245.61/web_docs/proceedings/Book_of_Abstracts_SEAVE G2012_rev.pdf. 
Waqaniu-Rogers, A. (1986). Some observations on duruka, Saccharum edule, in Viti Levu Fiji. Journal of the Polynesian Society, 95(4), 475-478.

Wasonga, D., Kleemola, J., Alakukku, L., \& Mäkelä, P. (2020). Growth response of cassava to deficit irrigation and potassium fertigation during the early growth phase. Agronomy, 10(3), 321. https:// doi.org/10.3390/agronomy10030321.

Webb, A.P. (2006). Coastal change analysis using multi-temporal image comparisons: Funafuti Atoll, Tuvalu. EU-SOPAC Project Report 54, Reducing Vulnerability of Pacific ACP States. Suva, Fiji: SOPAC Secretariat.

Wefels, E., Morin, J. P., \& Randles, J. W. (2015). Molecular evidence for a persistent-circulative association between coconut foliar decay virus and its vector Myndus taffini. Australasian Plant Pathology, 44, 283-288.

Wei, J., Liu, G., Liu, D., \& Chen, Y. (2017). Influence of irrigation during the growth stage on yield and quality in mango (Mangifera indica L). PLoS ONE, 12(4), e0174498. https://doi.org/10.1371/ journal.pone.0174498.

Westengen, O. T., \& Brysting, A. K. (2014). Crop adaptation to climate change in the semi-arid zone in Tanzania: The role of genetic resources and seed systems. Agriculture and Food Security. https:// doi.org/10.1186/2048-7010-3-3.

Whiley, A. W., Rasmussen, T. S., Saranah, J. B., \& Wolstenholme, B. N. (1989). Effect of temperature on growth, dry matter production and starch accumulation in ten mango (Mangifera indica L.) cultivars. Journal of Horticultural Science and Biotechnology, 64, 753-765.

Whitford, R., Gilbert, M., \& Langridge, P. (2010). Biotechnology in agriculture. In M. P. Reynolds (Ed.), Climate change and crop production (pp. 219-244). Wallingford, UK: CABI.

World Health Organization (WHO). (2000). Climate variability and change and their health effects in Pacific Island Countries. Report of a workshop held in Apia, Samoa, 25-28 July 2000. https:// apps.who.int/iris/handle/10665/66777.

World Trade Organisation (WTO). 2019. Natural disasters, and trade research study II: a legal mapping. Geneva, Switzerland: WTO. https://www.wto.org/english/tratop_e/devel_e/study2_sympn aturaldisaster29112019_e.pdf.

Wright, J.G., \& Peters, I. (2002). Yam Anthracnose. PEST ADVISORY LEAFLET NO. 12. Suva, Fiji: Pacific Community (SPC). https://www.ippc.int/static/media/files/pestreport/2013/07/10/1302820419 _pal_12_yam_anthracnose_201304232117en.pdf.

Xu, Y. (2010). Molecular plant breeding. Oxfordshire, UK: CABI.

$\mathrm{Xu}, \mathrm{Y}$. (2016). Envirotyping for deciphering environmental impacts on crop plants. Theoretical and Applied Genetics, 129(4), 653-673.

Yang, Z., Zhang, Z., Zhang, T., Fahad, S., Cui, K., \& Nie, L. (2017). The effect of season-long temperature increases on rice cultivars grown in the central and southern regions of China. Frontiers in Plant Science, 8, 1908. https://doi.org/10.3389/fpls.2017.01908.

Zhao, D., \& Li, Y. R. (2015). Climate change and sugarcane production: Potential impact and mitigation strategies. International Journal of Agronomy. https://doi.org/10.1155/2015/547386.

Zhou, Y., Taylor, M. B., \& Underhill, S. J. R. (2014). Dwarfing of breadfruit (Artocarpus altilis) trees: Opportunities and challenges. American Journal of Experimental Agriculture, 4(12), 1743-1763.

Zhou, Y., \& Underhill, S. J. R. (2019). A dwarf phenotype identified in breadfruit (Artocarpus altilis) plants growing on Marang (A. odoratissimus) rootstocks. Horticulturae, 5(2), 40. https://doi.org/10.3390/ horticulturae5020040.

Zuazo, V. H. D., Martínez-Raya, A., Ruiz, J. A., \& Tarifa, D. F. (2004). Impact of salinity on macro and micro nutrients uptake in mango (Mangifera indica L.cv Osteen) with different root stocks. Spanish Journal of Agricultural Research, 2(1), 121-133.

Publisher's Note Springer Nature remains neutral with regard to jurisdictional claims in published maps and institutional affiliations. 